
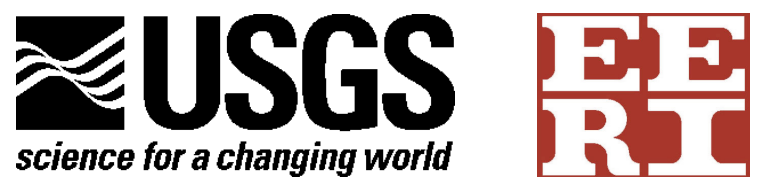

With material support from Earthquake Engineering Research Institute, U.S. National Science Foundation, National Earthquake Hazards Reduction Program, U.S. Agency for International Development, U.S. Southern Command, Applied Technology Council, Geo-Engineering Extreme Events Reconnaissance Association, and Network for Earthquake Engineering Simulation

\title{
The Mw 7.0 Haiti Earthquake of January 12, 2010: USGS/EERI Advance Reconnaissance Team Report
}

By Marc O. Eberhard, Steven Baldridge, Justin Marshall, Walter Mooney, and Glenn J. Rix


Open-File Report 2010-1048

U.S. Department of the Interior

U.S. Geological Survey 


\title{
U.S. Department of the Interior \\ KEN SALAZAR, Secretary
}

\author{
U.S. Geological Survey \\ Marcia K. McNutt, Director
}

U.S. Geological Survey, Reston, Virginia 2010

For product and ordering information:

World Wide Web: http://www.usgs.gov/pubprod

Telephone: 1-888-ASK-USGS

For more information on the USGS—-the Federal source for science about the Earth,its natural and living resources, natural hazards, and the environment:

World Wide Web: http://www.usgs.gov

Telephone: 1-888-ASK-USGS

Suggested citation:

Eberhard, M.O., Baldridge, Steven, Marshall, Justin, Mooney, Walter, and Rix, G.J., 2010, The Mw 7.0 Haiti earthquake of January 12, 2010; USGS/EERI Advance Reconnaissance Team report: U.S. Geological Survey Open-File Report 2010-1048, 58 p.

[http://pubs.usgs.gov/of/2010/1048/].

Any use of trade, product, or firm names is for descriptive purposes only and does not imply endorsement by the U.S. Government.

Although this report is in the public domain, permission must be secured from the individual copyright owners to reproduce any copyrighted material contained within this report.

FRONT COVER

Top left: Topography of Haiti with main shock of January 12, 2010 (star) and two weeks of aftershocks. Top right: Fissures caused by lateral spreading at the eastern end of the North Wharf, Port-au-Prince. Bottom: Collapsed columns at the Hotel Montana, a luxury facility. 


\section{Executive Summary}

A field reconnaissance in Haiti by a five-member team with expertise in seismology and earthquake engineering has revealed a number of factors that led to catastrophic losses of life and property during the January $12,2010, \mathrm{M}_{\mathrm{w}} 7.0$ earthquake. The field study was conducted from January 26 to February 3, 2010, and included investigations in Port-au-Prince and the heavily damaged communities to the west, including Léogâne, Grand Goâve, Petite Goâve, and Oliver.

\section{Seismology}

Despite recent seismic quiescence, Haiti has suffered similar devastating earthquakes in the historical past (1701, 1751, 1770 and 1860). Despite this knowledge of historical seismicity, Haiti had no seismograph stations during the main earthquake, so it is impossible to estimate accurately the intensity of ground motions. Nonetheless, the wide range of buildings damaged by the January 12, 2010, earthquake suggests that the ground motions contained seismic energy over a wide range of frequencies. Another earthquake of similar magnitude could strike at any time on the eastern end of the Enriquillo Fault, directly to the south of Port-au-Prince (Manaker and others, 2008). Reconstruction must take this hazard into account.

The four portable seismographs installed by the team recorded a series of small aftershocks. As expected, the ground motions recorded at a hard-rock site contained a greater proportion of high frequencies than the motions recorded at a soil site. Two of the stations continue to monitor seismic activity.

A thorough field investigation of the mapped Enriquillo Fault south of the city of Léogâne failed to find any evidence of surface faulting. This led the team to conclude that the earthquake was unlikely to have produced any surface rupture in the study area.

\section{Geotechnical Aspects}

Soil liquefaction, landslides and rockslides in cut slopes, and road embankment failures contributed to extensive damage in Port-au-Prince and elsewhere. A lack of detailed knowledge of the physical conditions of the soils (for example, lithology, stiffness, density, and thickness) made it difficult for us to quantitatively assess the role of ground-motion amplification in the widespread damage.

\section{Buildings}

The Haitian Ministry of Statistics and Informatics reported that one-story buildings represent 73 percent of the building inventory. Most ordinary, one-story houses have roofs made of sheet metal ( 82 percent), whereas most multistory houses and apartments have roofs made of concrete (71 percent). Walls made of concrete/block/stone predominate both in ordinary houses and apartments.

It appears that the widespread damage to residences and commercial and government buildings was attributable to a great extent to the lack of earthquake-resistant design. In many cases, the structural types, member dimensions, and detailing practices were inadequate to resist 
strong ground motions. These vulnerabilities may have been exacerbated by poor construction practices. Reinforced concrete frames with concrete block masonry infill appeared to perform particularly poorly. Structures with light (timber or sheet metal) roofs performed better compared to structures with concrete roofs and slabs.

The seismic performance of some buildings was adequate, and some of the damaged buildings appeared to have had low deformation demands. These observations suggest that structures designed and constructed with adequate stiffness and reinforcing details would have resisted the earthquake without being damaged severely.

A damage survey of 107 buildings in downtown Port-au-Prince indicated that 28 percent had collapsed and another 33 percent were damaged enough to require repairs. A similar survey of 52 buildings in Léogâne found that 62 percent had collapsed and another 31 percent required repairs.

\section{Bridges}

There was no evidence of bridge collapses attributable to the earthquake. Most bridges in Port-au-Prince are simple box culverts consisting of box girders 2.0 to 2.5 meter (6 to $8 \mathrm{ft}$ ) deep. However, in several cases the roadway settled differentially between the approaches and the section spanning the culvert. Multispan bridges on primary routes are engineered structures that experienced some damage but are still serviceable.

\section{Port Facilities}

The main port in Port-au-Prince suffered extensive damage during the earthquake, inhibiting the delivery of relief supplies. The collapse of the North Wharf appears to have been caused by liquefaction-induced lateral spreading. The westernmost 120 meters ( $400 \mathrm{ft}$ ) of the South Pier collapsed, and approximately 85 percent of the vertical and batter piles supporting the remaining section were moderately damaged or broken. The remaining section of pier was shut down to vehicle traffic following additional damage that occurred during an aftershock. The collapse of a pile-supported pier at the Varreux Terminal resulted in the deaths of about 30 people working on the pier at the time of the earthquake. Less severe damage, including a small oil spill, occurred at a marine oil terminal located near Port-au-Prince.

\section{Damage to Institutions}

The functioning of the government and social infrastructure was seriously deteriorated by the loss of personnel, records, and facilities. Such losses occurred in numerous clinics, hospitals, police stations, schools, universities, palaces, ministries, and churches. These losses have compromised the recovery and reconstruction efforts.

\section{Satellite Imagery}

The use of remote sensing data, including satellite and aerial imagery, proved highly effective in assisting damage assessment, evaluating the extent of landslides, and guiding rescue and recovery efforts. Light detection and ranging (LIDAR) technology has been effective to create three-dimensional images for damage assessment and rebuilding operations. 


\section{Conclusions}

The massive human losses in this earthquake can be attributed to a lack of attention to earthquake-resistant design and construction practices and the poor quality of much of the construction. The historical pattern of earthquakes in Haiti indicates that an earthquake of magnitude 7 or larger could strike southern Haiti near Port-au-Prince at any time. Reconstruction must therefore be based on sound, simple, and cost-effective engineering practice for all possible natural hazards. These principles must be clearly communicated to the citizens of Haiti. Additional fact gathering is needed, both to quantify the January 12th fault rupture and earthquake history (inputs to calculations of future earthquake probabilities), and to more comprehensively evaluate damage to buildings and infrastructure, so as to inform decisions about reconstruction. 


\section{Contents}

Executive Summary iii

Introduction 2

Seismological Aspects 3

Geology and Tectonics 3

Seismicity 3

The Main Shock and Aftershocks 4

Seismological Field Activities $\quad 5$

Investigations of Surface Faulting 9

Geotechnical Aspects $\quad 10$

Liquefaction 10

Ground-Motion Amplification 10

Landslides 11

Embankment Failures $\quad 11$

$\begin{array}{ll}\text { Buildings } & 14\end{array}$

Building and Housing Statistics $\quad 14$

$\begin{array}{ll}\text { Residential Buildings } & 15\end{array}$

Multistory Reinforced Concrete and Masonry Structures $\quad 19$

Case History: Hotel Montana 19

Case History: Two-Story RC Frame with CMU Infill 24

Case History: 4-5-Story RC Frame under Construction 26

Case History: Moment-Frame Buildings Designed for Earthquake Resistance 29

Pre-Engineered Metal Buildings $\quad 32$

Nonstructural Damage $\quad 33$

Quantification of Damage $\quad 37$

Bridges

Port Facilities

$\begin{array}{ll}\text { Port de Port-au-Prince } & 40\end{array}$

$\begin{array}{ll}\text { Thor Marine Oil Terminal } & 46\end{array}$

$\begin{array}{ll}\text { Varreux Terminal } & 47\end{array}$

Port du Cap Haïtien $\quad 47$

Damage To Institutions 48

Satellite Imagery

Final Remarks

References $\quad 55$

Appendix A: Statistics on Haitian Housing 57 


\title{
The $\boldsymbol{M}_{w} 7.0$ Haiti Earthquake of January 12, 2010: USGS/EERI Advance Reconnaissance Team Report
}

\author{
By Marc 0. Eberhard ${ }^{1}$, Steven Baldridge ${ }^{2}$, Justin Marshall ${ }^{3}$, Walter Mooney ${ }^{4}$, and \\ Glenn J. Rix ${ }^{5}$
}

From January 26 to February 3, 2010, a team organized by the U.S. Geological Survey and the Earthquake Engineering Research Institute investigated the effects of the January 12, 2010 Haiti earthquake. The multidisciplinary team was composed of Marc Eberhard, University of Washington (team leader); Steve Baldridge, Baldridge \& Associates Structural Engineering, Inc.; Justin Marshall, Auburn University; Walter Mooney, U.S. Geological Survey; and Glenn Rix, Georgia Institute of Technology. In addition to conducting earthquake damage reconnaissance, the team installed four seismograph stations in Haiti; participated in assessments of numerous buildings, bridges and port facilities; and trained engineers in postearthquake assessment.

The reconnaissance effort was made possible by the logistical support of the U.S. Southern Command and the officers, soldiers, marines, airmen, and civilians of Joint Task Force Haiti. The institutional support of the U.S. Embassy and U.S. Agency for International Development was also crucial. Travel funding for the team was provided by the U.S. Geological Survey (USGS), Earthquake Engineering Research Institute (EERI), Network for Earthquake Engineering Simulation (NEES), Geo-Engineering Extreme Events Reconnaissance (GEER) Association, and Applied Technology Council (ATC). The EERI contribution was funded by the EERI Learning from Earthquakes project under Award No. CMMI-0758529 from the U.S. National Science Foundation.

\footnotetext{
1University of Washington

2Baldridge \& Associates Structural Engineering, Inc.

3Auburn University

${ }^{4}$ U.S. Geological Survey

${ }^{5}$ Georgia Institute of Technology
} 


\section{Introduction}

The $M_{w} 7.0$ earthquake that struck the Republic of Haiti on January 12, 2010, is among the most destructive earthquakes in recorded history. As of February 16, 2010, the death toll reported by the Government of Haiti exceeds 217,000, with an additional 300,000 people injured. More than 5 million people live in the area directly affected by the earthquake, and 1.2 million people are now living in temporary shelters (United Nations, 2010). Five weeks after the earthquake, humanitarian relief agencies continue to be challenged by the scale of the disaster.

The Republic of Haiti occupies the western third $\left(27,750 \mathrm{~km}^{2}\right)$ of the island of Hispaniola, located in the northeastern Caribbean between Puerto Rico to the east and Jamaica and Cuba to the west (fig. 1) and has a total population of approximately 9 million. Its largest city, Port-au-Prince, has an estimated population of between 2.5 and 3 million people within the metropolitan area and is located $25 \mathrm{~km}$ eastnortheast of the epicenter. Haiti is the poorest country in the Western Hemisphere, with an estimated 80 percent of its people living under the poverty line; 54 percent live in abject poverty (Central Intelligence Agency, 2010).

Haiti has been impacted by other natural disasters as well. In 2008, more than 800 people were killed by a series of four hurricanes and tropical storms that struck Haiti during a two-month period.

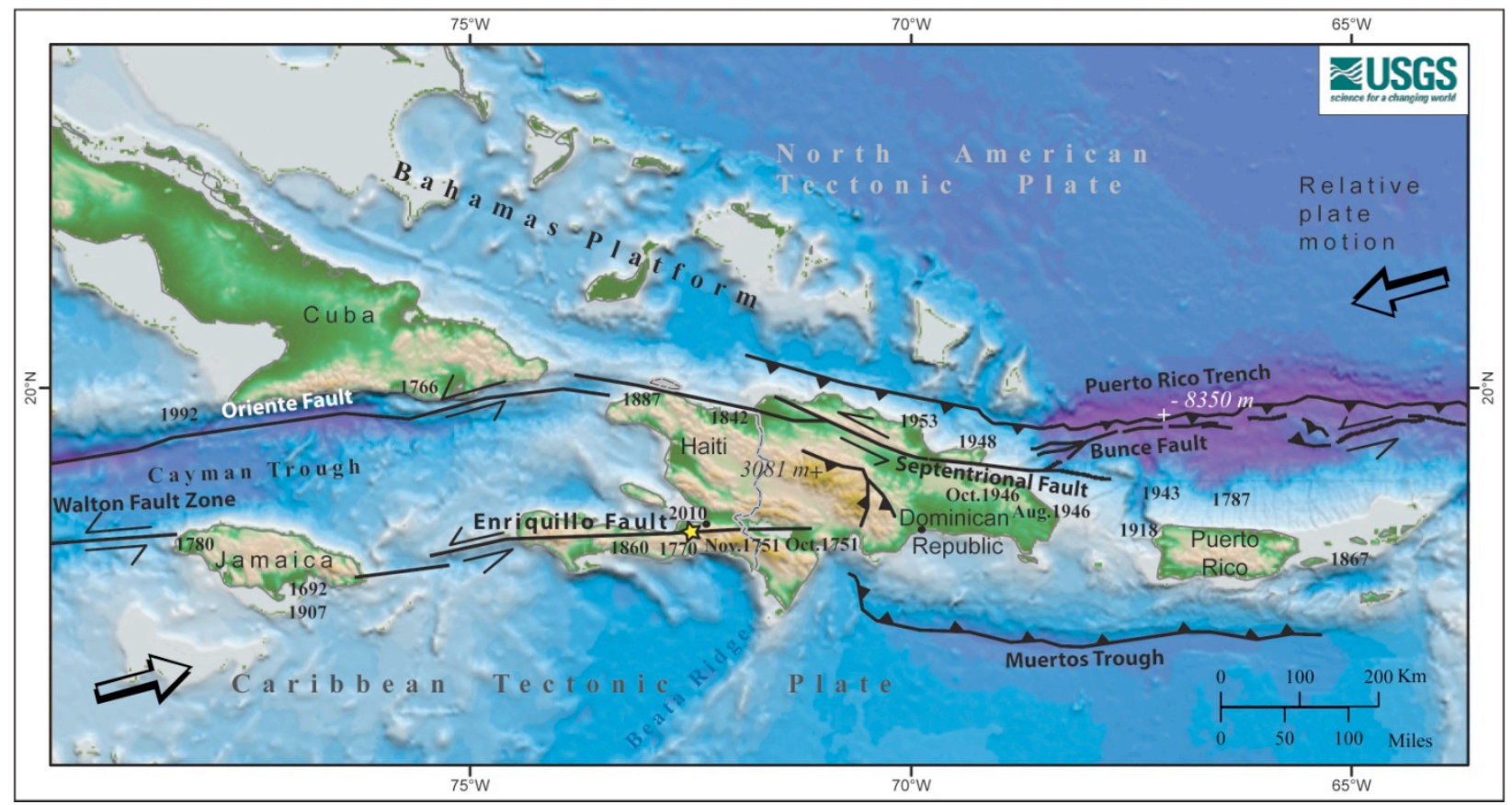

Figure 1. Geographical setting of the island of Hispaniola; Haiti occupies the western third. The location of the January 12, 2010, earthquake is indicated (star), as are the locations of historical earthquakes that occurred on the Enriquillo Fault (1751 (two events), 1770, and 1860) (Source: ten Brink and Andrews, 2010). 


\section{Seismological Aspects}

\section{Geology and Tectonics}

The geologic evolution of Hispaniola can be traced to the Mesozoic breakup of Pangea and the creation of the Atlantic Ocean. In the Caribbean this process resulted in a microplate with subduction zones forming around the margins (Garcia-Casco and others, 2008). The geology of Hispaniola, including Haiti, consists of igneous rocks formed within a volcanic island arc, as well as abundant marine sedimentary rocks that have accreted at the oceanic subduction margin.

The subparallel Enriquillo and Septentrional Faults are the principal active faults forming the plate boundary between the Caribbean and North American tectonic plates in the Greater Antilles (fig. 1). Recent geodetic surveys show that both faults are locked and are accumulating strain that will eventually be released in large earthquakes (Manaker and others, 2008). The January 12, 2010, earthquake occurred on the Enriquillo Fault system, a prominent strike-slip fault that is clearly evident in high-resolution relief maps of the Southern Peninsula of Haiti. Our field studies confirmed that the mapped Enriquillo Fault in the epicentral zone west-southwest of Port-au-Prince separates basaltic rocks south of the fault from marine sedimentary rocks (chalk, sandstone, and limestone) to the north. Thus, the fault can be easily discerned by its morphology and geology.

\section{Seismicity}

During the 20th century, and prior to the January 12, 2010, earthquake, seismic activity within the island of Hispaniola had been concentrated on the eastern two-thirds of the island in the Dominican Republic, and Haiti had been seismically quiescent. Indeed, since the establishment of a modern global seismic network in 1964, earthquake catalogs indicate that the Port-au-Prince region of southern Haiti has experienced only one earthquake of magnitude greater than 4.0, with several additional events occurring $100 \mathrm{~km}$ to the west. This low level of seismic activity may explain the equally low level of earthquake preparedness in Haiti prior to the 2010 event.

However, studies of historical seismicity have established that large earthquakes (magnitude 7.0 or greater) have struck the Port-au-Prince region in the past. These earthquakes are all attributed to movement on the east-west-oriented Enriquillo Fault (fig. 1). The largest earthquakes occurred in 1701, 1751, 1770, and 1860 (Scherer, 1912; O'Loughlin and Lander, 2003). The November 21, 1751 event occurred at the longitude of Port-au-Prince and destroyed buildings throughout the city (Modified Mercalli Intensity of X). The June 3, 1770 earthquake occurred an estimated 30-50 km further to the west on the Enriquillo Fault and once again resulted in the widespread destruction of buildings in Port-au-Prince and Léogâne (Scherer, 1912; O'Loughlin and Lander, 2003). The 1860 earthquake was located still further to the west of Port-auPrince and was observed to cause uplift of the sea floor. Thus, despite recent quiescence, the Southern Peninsula, and in particular the Port-au-Prince and Léogâne regions, have a well-documented history of deadly earthquakes. 


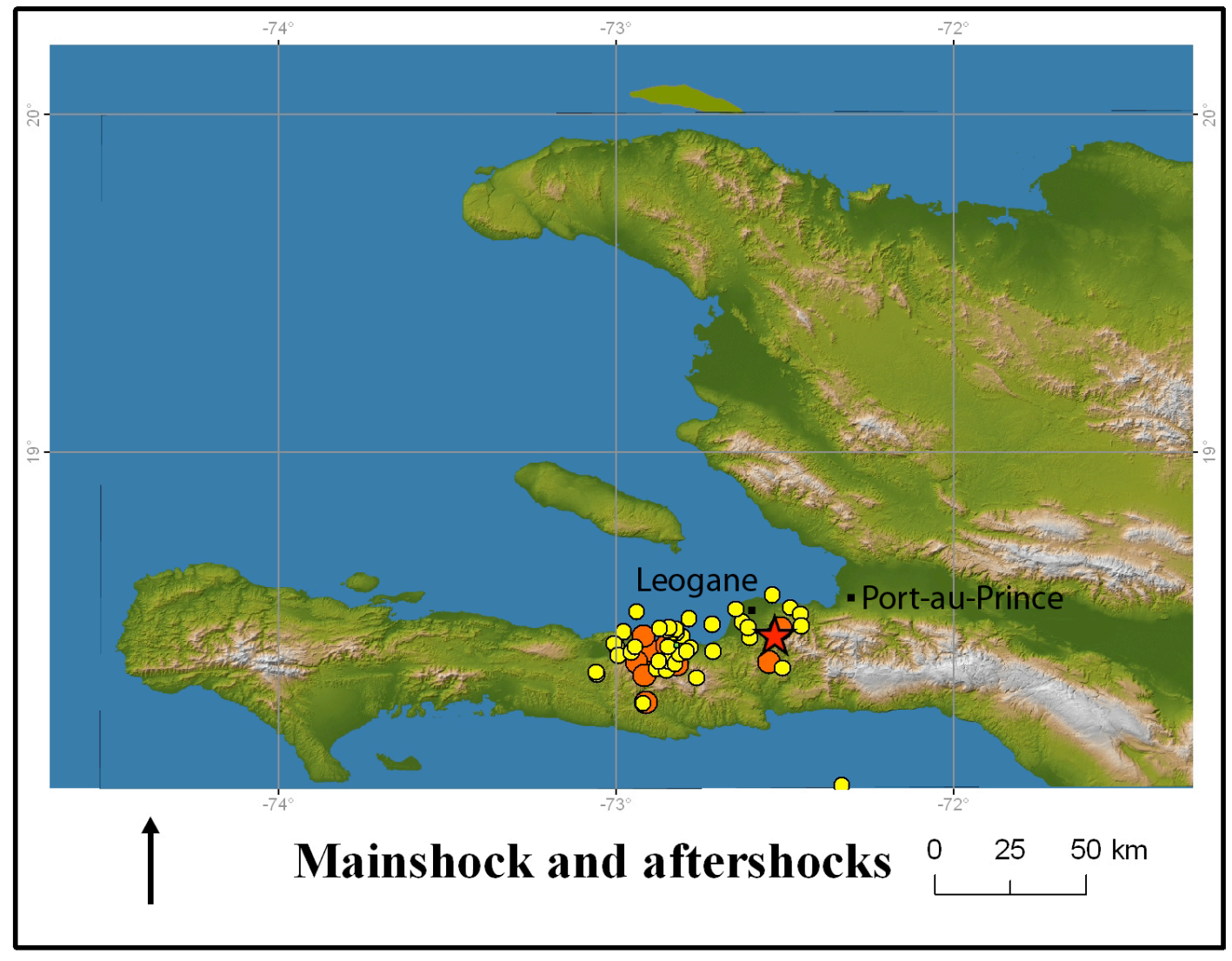

Figure 2. Topographic map of Haiti with locations of the January 12, 2010, main shock (star) and aftershocks that occurred within the first two weeks. Many aftershocks occurred some 40-50 km west of the main shock, at the west end of the subsurface fault rupture.

\section{The Main Shock and Aftershocks}

The January 12, 2010, event occurred at 04:53 p.m. local time. The U.S. Geological Survey (USGS) epicenter is $18.457^{\circ} \mathrm{N}, 72.533^{\circ} \mathrm{W}$, which places the event $25 \mathrm{~km}$ west-southwest of Port-au-Prince on or near the Enriquillo Fault (fig. 2; U.S. Geological Survey, 2010). The estimated depth is $13 \mathrm{~km}$, but the lack of local seismic data makes the precise depth uncertain. The USGS assigned a horizontal uncertainty of $+/-$ $3.4 \mathrm{~km}$. The focal mechanism for the main shock indicates left-lateral oblique-slip motion on an east-west oriented fault. The fault ruptured from east to west, away from Port-au-Prince and towards the cities of Léogâne, Grand Goâve, and Petite Goâve. The USGS finite-fault model shows a maximum slip of $5 \mathrm{~m}$ updip from the hypocenter (fig. 3). The earthquake source zone (that is, the surface area of the fault that slipped) is quite compact, with a downdip dimension of approximately $15 \mathrm{~km}$ and an along-strike dimension of $30 \mathrm{~km}$. This source dimension is about one-third the size of a typical $M_{w} 7.0$ earthquake. The earthquake rupture was very abrupt and sharp; maximum moment release occurred in the first 10 seconds of the fault slip. 

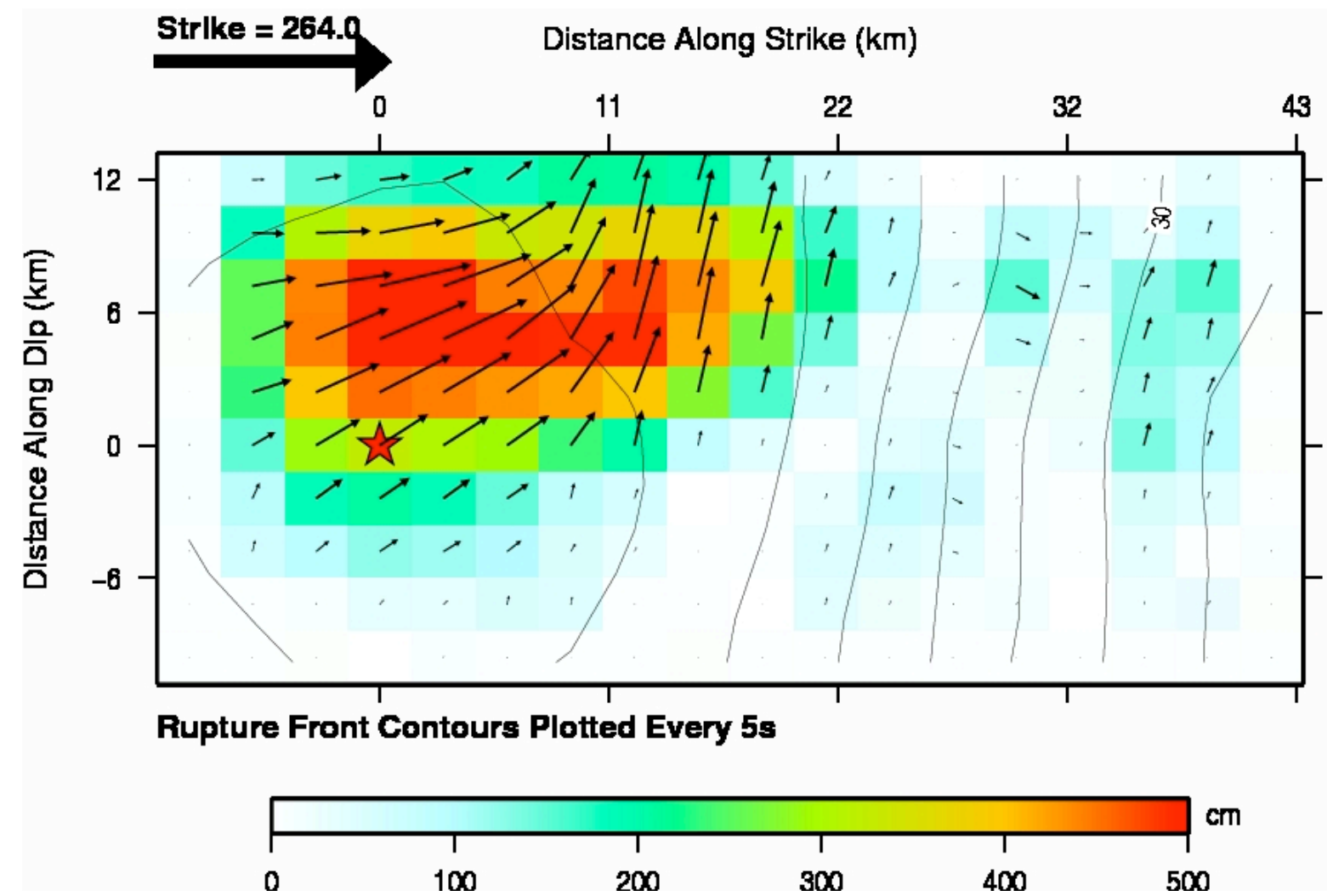

Figure 3. USGS finite-fault model (Hayes, 2010) indicating the amount of slip on the fault plane during the January 12,2010 , Haiti earthquake. West is to the right. The surface area with slip greater than about $2 \mathrm{~m}$ is quite compact, with a length of about $30 \mathrm{~km}$ and downdip extent of about $15 \mathrm{~km}$.

The main shock was followed within 20 minutes by two large aftershocks with moment magnitudes of 6.0 and 5.7, respectively. On January 20, 2010, a $M_{w} 5.9$ aftershock caused great alarm among local residents, many of whom were living in temporary shelters. Overall, the number of aftershocks from this earthquake was three times more than a typical aftershock sequence in California.

\section{Seismological Field Activities}

We deployed four Kinemetrics K2 accelerometer seismographs during our field reconnaissance. The first seismograph was installed on the grounds of the U.S. Embassy (table 1 and fig. 4) on the evening of January 27, 2010. Good road conditions enabled us to efficiently deploy seismographs along Nationale No. 2 that extends from Port-au-Prince through Carrefour and Léogâne and continues to the west. The second and third seismographs were installed on January 29, 2010, in the towns of Grand Goâve and Oliver located $58 \mathrm{~km}$ and $88 \mathrm{~km}$ west of the U.S. Embassy site, respectively. The fourth seismograph suffered a blown fuse, was repaired, and deployed at a hard-rock site at Killick Naval Hospital in Port-au-Prince on February 2, 2010. Prior to leaving Haiti, we recovered data from three of the four seismographs. Because the Killick Naval Hospital seismograph was deployed at the end of our reconnaissance, data have not yet been recovered from it. The U.S. Embassy and Killick Naval Hospital seismographs are AC powered and will continue to operate indefinitely.

Figure 5 shows data from an earthquake recorded by the seismographs at the U.S. Embassy and Oliver Elementary School. The U.S. Embassy site (upper three traces of fig. 5) has lower frequency content and longer duration shaking compared to the station at Oliver Elementary School (lower three traces of fig. 5 ). We are currently evaluating all of the data recorded in the time period January 27 through February 2 , 2010, for epicentral location, seismic amplitudes, frequency content, and duration of shaking. The 
recording of additional data from other locations distributed throughout the Port-au-Prince region would provide valuable information for microzonation studies.

Table 1. Location of Seismograph Stations

\begin{tabular}{|l|c|c|c|}
\hline \multicolumn{1}{|c|}{ Station Name } & Latitude & Longitude & Period of Operation \\
\hline U.S. Embassy & $18.56460^{\circ} \mathrm{N}$ & $72.24851^{\circ} \mathrm{W}$ & January 27, 2010, to present \\
\hline Grand Goâve & $18.42057^{\circ} \mathrm{N}$ & $72.77292^{\circ} \mathrm{W}$ & January 29-February 2, 2010 \\
\hline Oliver Elementary School & $18.42642^{\circ} \mathrm{N}$ & $73.03968^{\circ} \mathrm{W}$ & January 29-February 2, 2010 \\
\hline Killick Naval Hospital & $18.53296^{\circ} \mathrm{N}$ & $72.37953^{\circ} \mathrm{W}$ & February 2, 2010, to present \\
\hline
\end{tabular}




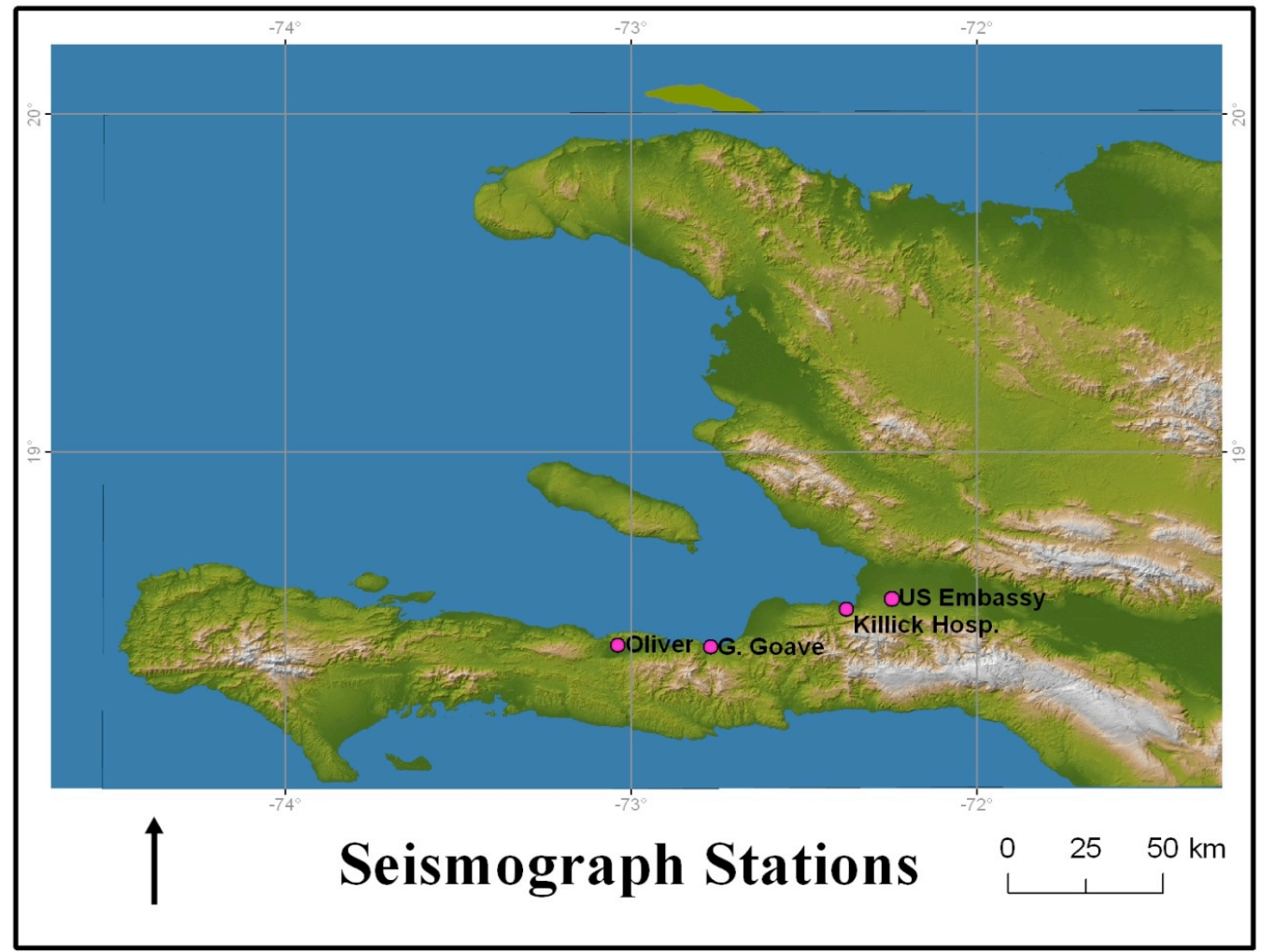

Figure 4. Location map for the four Kinemetrics K2 seismograph (accelerometer) stations. The stations at the U.S. Embassy and Killick Naval Hospital are currently operating; the Grand Goâve and Oliver Elementary School stations operated only between January 29 and February 2, 2010. 


\section{HAITI AFTERSHOCK, 2010/01/29 21:55 UT}

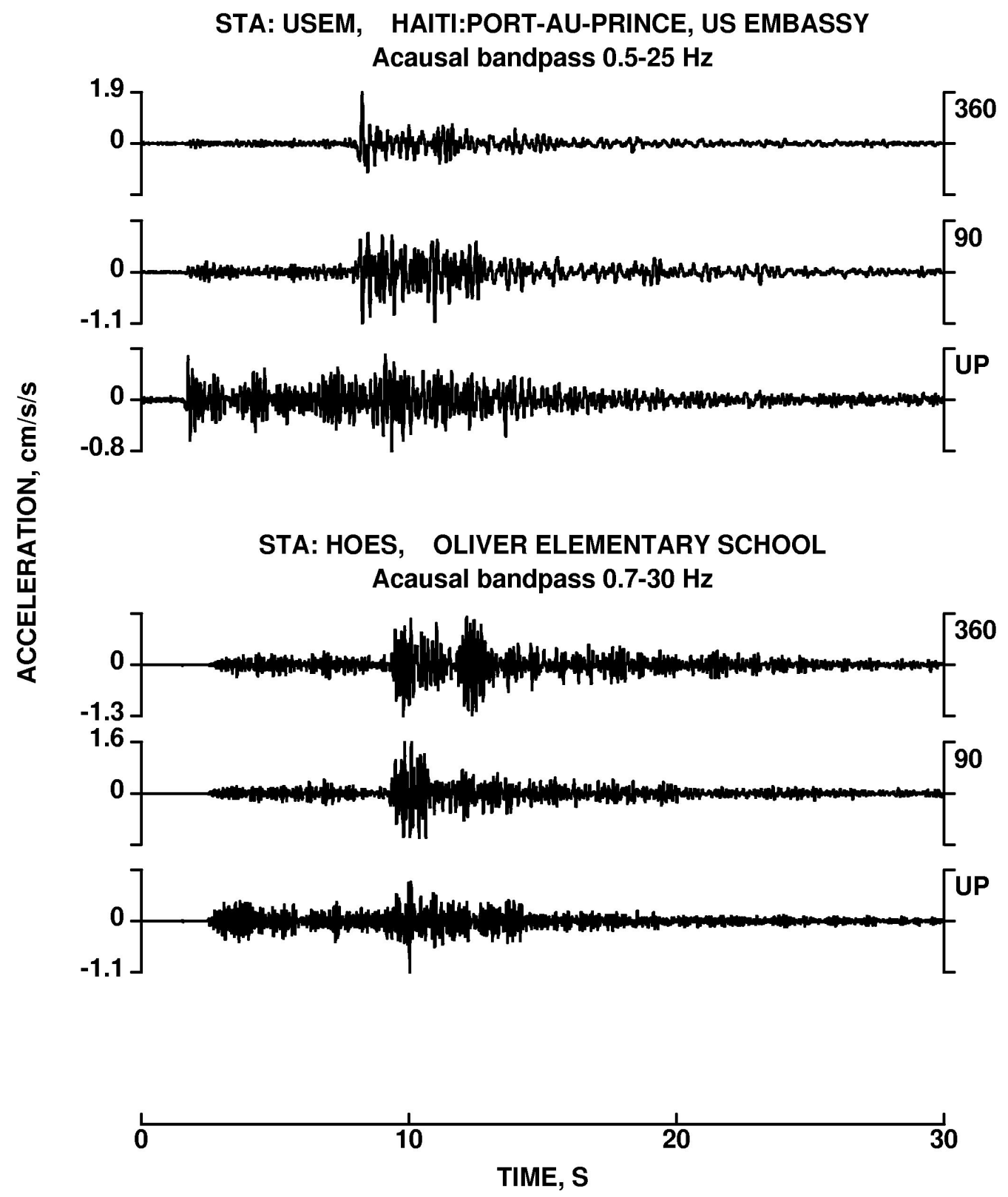

Figure 5. Sample data recorded by seismographs at the U.S. Embassy and at the Oliver Elementary School. 


\section{Investigations of Surface Faulting}

A thorough search was made for surface rupture caused by the earthquake. Many crustal earthquakes with $M_{w} 7.0$ or greater are accompanied by surface rupture that can be traced for tens of kilometers. However, U.S.-based remote sensing experts have reported no success in identifying surface rupture from satellite imagery. Land-based investigations conducted between January 22 and 26, 2010, by other investigators identified only roadway cracking and slumping, not surface ruptures.

Our search for surface ruptures during the period January 28-February 2, 2010, consisted of three parts: (1) a one-day field study in the earthquake epicentral region near the city of Fayette; (2) a thorough examination of roadways and drainage embankments in and around the town of Dufort (where the geologically mapped Enriquillo Fault crosses the roadway); and (3) interviews with more than 30 individuals who live along the geologically mapped trace of the Enriquillo Fault. The last activity was considered to be highly effective because the local residents make frequent and widespread excursions throughout the fields in the region affected by the earthquake. If surface rupture exists, they would almost certainly have found it.

Our field investigations failed to discover any evidence of surface faulting. Numerous cracks in the roadway could all be attributed to slumping of road embankments, which rise as much as $3 \mathrm{~m}(9.8 \mathrm{ft})$ above the adjoining fields. Indeed, many of the most prominent road cracks were oriented north-south, while the Enriquillo Fault is oriented east-west. An examination of the fields adjacent to the cracked roadway consistently revealed no surface rupture, with the exception of a crack adjacent to the road that was oriented north-south. A field study along the coastline centered at $18.44609^{\circ} \mathrm{N}, 72.685912^{\circ} \mathrm{W}$ did not reveal surface rupture, despite clear liquefaction features in a nearby field.

We conclude that surface faulting is unlikely to exist in the region west of the epicentral zone near the town of Fayette and up to and including the coastline west of the town of Dufort. In view of the lack of evidence for surface rupture in the field and in satellite imagery, it appears that this earthquake did not produce any surface rupture. The absence of an identifiable surface rupture along the geologically mapped Enriquillo Fault raises the question of which subsurface fault strand actually ruptured on January 12, 2010. Similar to the $M_{w} 6.9$ Loma Prieta, California, earthquake of 1989 that occurred several kilometers off the San Andreas Fault, this earthquake may have occurred several kilometers off the mapped strand of the Enriquillo Fault. 


\section{Geotechnical Aspects}

\section{Liquefaction}

Liquefaction-induced lateral spreading was a significant factor contributing to the extensive damage at the Port de Port-au-Prince, especially the collapse of a pile-supported marginal wharf. The liquefaction features and resulting damage are described in more detail in a subsequent section of this report on the port.

Other less severe liquefaction-related features were observed in the alluvial plain surrounding the city of Léogâne. Figure 6 shows the failure of a structure located about $75 \mathrm{~m}(246 \mathrm{ft})$ from the shoreline at $18.446323^{\circ} \mathrm{N}, 72.686259^{\circ} \mathrm{W}$. There were several sand boils nearby, the largest of which measured

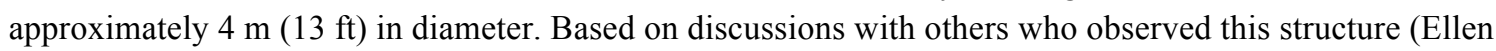
Rathje and Russell Green, personal commun., 2010), it is likely that a combination of structural and foundation failures contributed to the collapse of the structure.

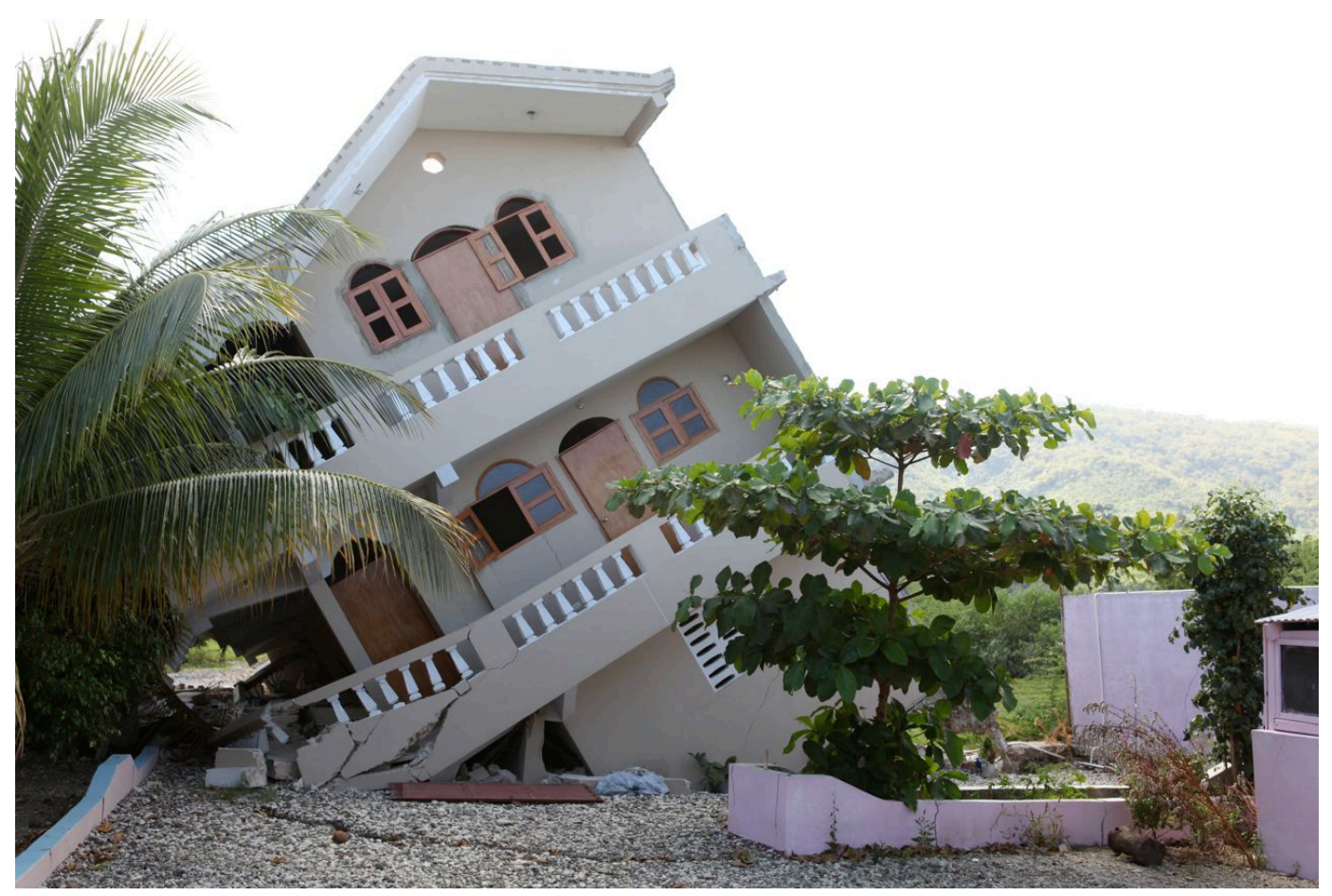

Figure 6. Combined structural and foundation failure southwest of Léogâne.

\section{Ground-Motion Amplification}

The role of ground-motion amplification in causing the widespread damage observed in Port-auPrince is unclear at present because little is known about soil conditions. Port-au-Prince lies in the Cul-deSac-Enriquillo graben (also called the Cul-de-Sac Plain) that divides Hispaniola into two different geologic provinces. To the north of Port-au-Prince is the "Chaine des Mateux" mountain range. To the south lie the foothills of the La Selle Mountains that form the backdrop of the city. Most of Port-au-Prince rests on Holocene alluvial fan deposits consisting of gravel, sand, and clay (Woodring and others, 1924; Maurrasse, 1982). The thickness of the deposits is variable and is reported to reach more than $200 \mathrm{~m}(650 \mathrm{ft})$ in some locations (Emmanuel and others, 2004). In describing groundwater conditions in Port-au-Prince, Emmanuel and others (2004) noted the presence of several distinct layers that provides some insight into the nature of 
the deposits: (1) a surface layer of clayey sand ranging in thickness from a few meters to a maximum of 30 $\mathrm{m}(100 \mathrm{ft}) ;(2)$ a layer composed of sands and gravels between 30 and $60 \mathrm{~m}$ (100 and $200 \mathrm{ft})$ in depth; and (3) a gravel layer between 60 and $150 \mathrm{~m}$ (200 and $500 \mathrm{ft})$ in depth. Gathering more detailed information about the soils in Port-au-Prince and evaluating site effects are items deserving further study. Similar studies should also be performed to understand site effects in the alluvial soils near Léogâne.

\section{Landslides}

We observed a large number of landslides along Highway 204 in the mountainous area approximately 10-15 km southwest of the epicenter. Most of these landslides occurred in cut slopes along the highway (fig. 7A). We did not observe many landslides in natural slopes away from the highway. We also observed several landslides in the foothills of the La Selle mountains between downtown Port-auPrince and Pétion-Ville. Figure $7 B$ shows an example of one such landslide that destroyed several homes on top of the slope.

\section{Embankment Failures}

Two failures that caused damage to the pavement were observed along Nationale No. 2 west of the epicenter where the road is constructed on an embankment above low-lying coastal areas. In the first case $\left(18.473550^{\circ} \mathrm{N}, 72.632383^{\circ} \mathrm{W}\right)$, the pavement damage appears to have been caused by a slope failure (fig. $8 A)$. The cause of damage in the second case $\left(18.423130^{\circ} \mathrm{N}, 72.724660^{\circ} \mathrm{W}\right)$ is more complex and may be the result of dynamic densification of the fill because the pavement has settled by approximately $1 \mathrm{~m}(3.3$ ft) (fig. $8 B$ ). 

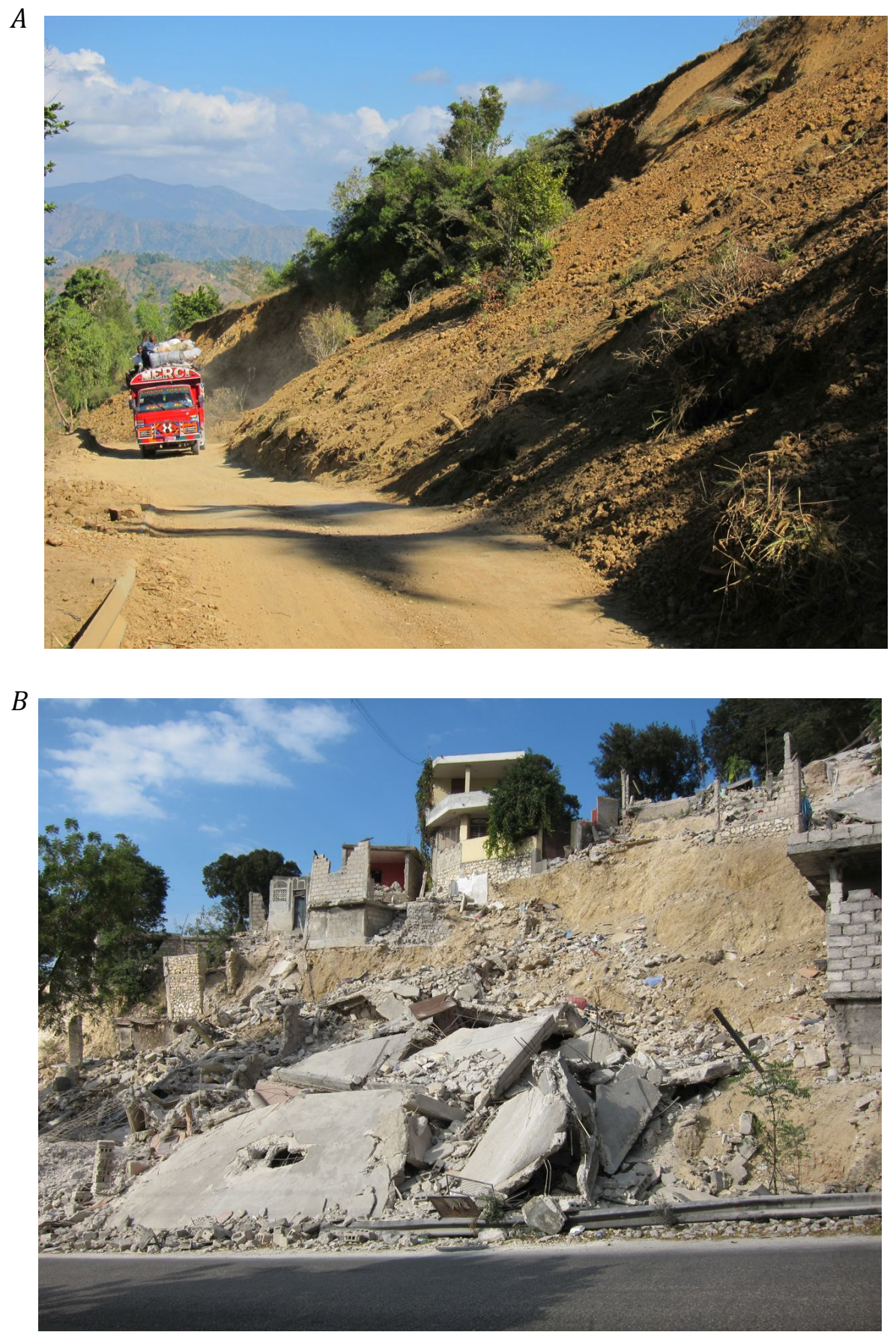

Figure 7. Landslides $(A)$ along Highway 204 and $(B)$ near Pétion-Ville. 

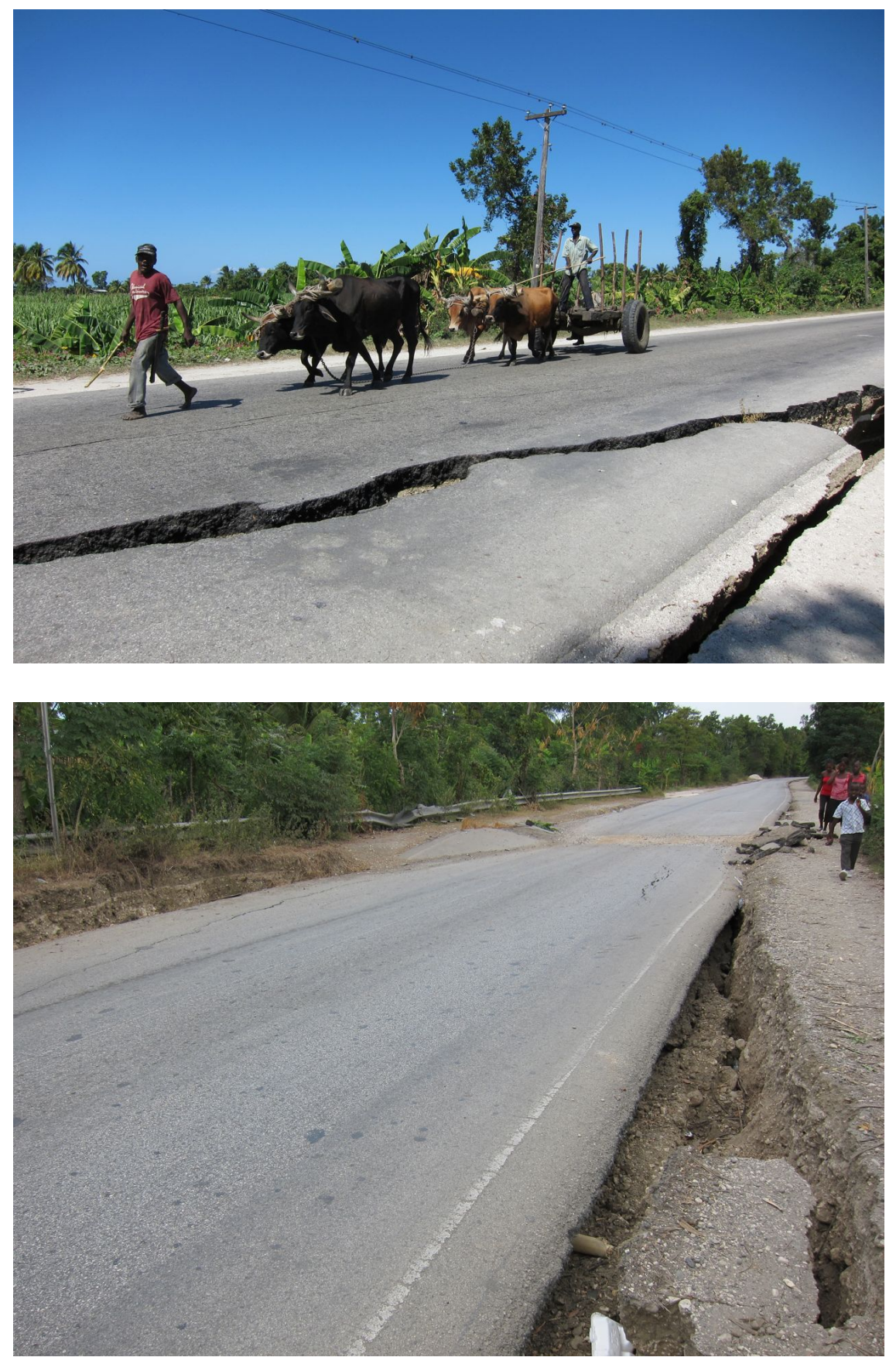

Figure 8. Roadway embankment failures. 


\section{Buildings}

The earthquake caused extensive damage to buildings throughout the Port-au-Prince region and in the rural areas and towns to the west of the city. Based on our investigation, this section provides an overview of Haitian building and housing statistics, typical construction practices and damage to residential construction. We report on the performance of reinforced concrete and masonry structures and illustrate key features with four case studies. The section concludes with a discussion of the performance of prefabricated steel frames and a quantitative survey of distributed damage for two sample areas.

\section{Building and Housing Statistics}

During 2001, the Haitian Ministry of Statistics and Informatics (in French, Institute Haïtien de Statistique et d'Informatique, IHSI) gathered extensive data on the living conditions in Haiti. Based on this information, the IHSI website summarizes the characteristics of buildings in Haiti (Institute Haitien de Statistique et d'Informatique,, 2010a). Risk Management Solutions (2010) provides a partial translation of one of the pages on the website (Institute Haïtien de Statistique et d'Informatique,, 2010a). The IHSI report (Institute Haitien de Statistique et d'Informatique,, 2003) provides much more detail, but it reports statistics in terms of housing units ("logements") instead of buildings. Appendix A provides our translation into English of some of the key tables from the 2003 report.

According to Institute Haïtien de Statistique et d'Informatique (2010a), one-story buildings ("maison basse") represent $73 \%$ percentof the building inventory. It is not clear from the website whether this statistic reflects all building types or only those housing people. This percentage is higher in urban regions (79 percent) and lower in rural regions ( 69 percent). Multistory structures (5 percent) and other types of structures ( 5 percent) are less common. The walls of 90 percent of buildings are constructed of one of the four following materials: (1) cement/block; (2) earthen materials; (3) clisse ("clissage" can be translated as "intertwined sticks, twigs, and branches"); and (4) bricks/stone. In rural regions, walls are most commonly made of earthen materials (33 percent), whereas in urban regions cement/block walls are the most common (79 Percent). Metal roofs predominate in both rural (74 percent) and urban regions (63 ercent).

According to the housing statistics, ordinary, one-story houses represent approximately 60 percent of the housing units, both in the Port-au-Prince region and in rural areas. In the Port-au-Prince region, multistory houses and apartments make up most of the remaining units (30 percent). In rural regions, most of the remaining housing units consist of Kay Atè ( 9 percent) and Taudis/Ajoupas (19 percent), housing types that are defined in appendix A.

Institute Haïtien de Statistique et d'Informatique (2003) also reports data on the materials used for key building components:

- ROOFS: Most ordinary, one-story houses have roofs made of sheet metal (82 percent), but most multistory houses and apartments have roofs made of concrete (71 percent).

- WALLS: Walls made of concrete/block/stone predominate in ordinary, one-story houses (76 percent) and predominate even more in ordinary, multistory houses and apartments (97 percent).

- FLOORS: Ordinary, one-story houses usually have floors made of concrete (64 percent) or compacted earth (31 percent). Multistory houses and apartments usually have floors made of concrete (69 percent) or mosaic/planks (24 percent).

Although the statistics on materials are reported for the country of Haiti as a whole, they appear to be consistent with our field observations of the areas affected by the earthquake. 


\section{Residential Buildings}

Based on our field observations, residential construction in Port-au-Prince can be roughly divided into three categories:

- Shanty housing using a mixture of wood and corrugated metal

- Concrete masonry unit (CMU, also called concrete block) with corrugated-metal roof

- Reinforced concrete columns and slabs with infill concrete block walls.

We did not see much damage or collapse in the first two categories of residential construction (fig. 9). The lower weight of the building materials in these types of construction likely resulted in lower seismic inertial forces.

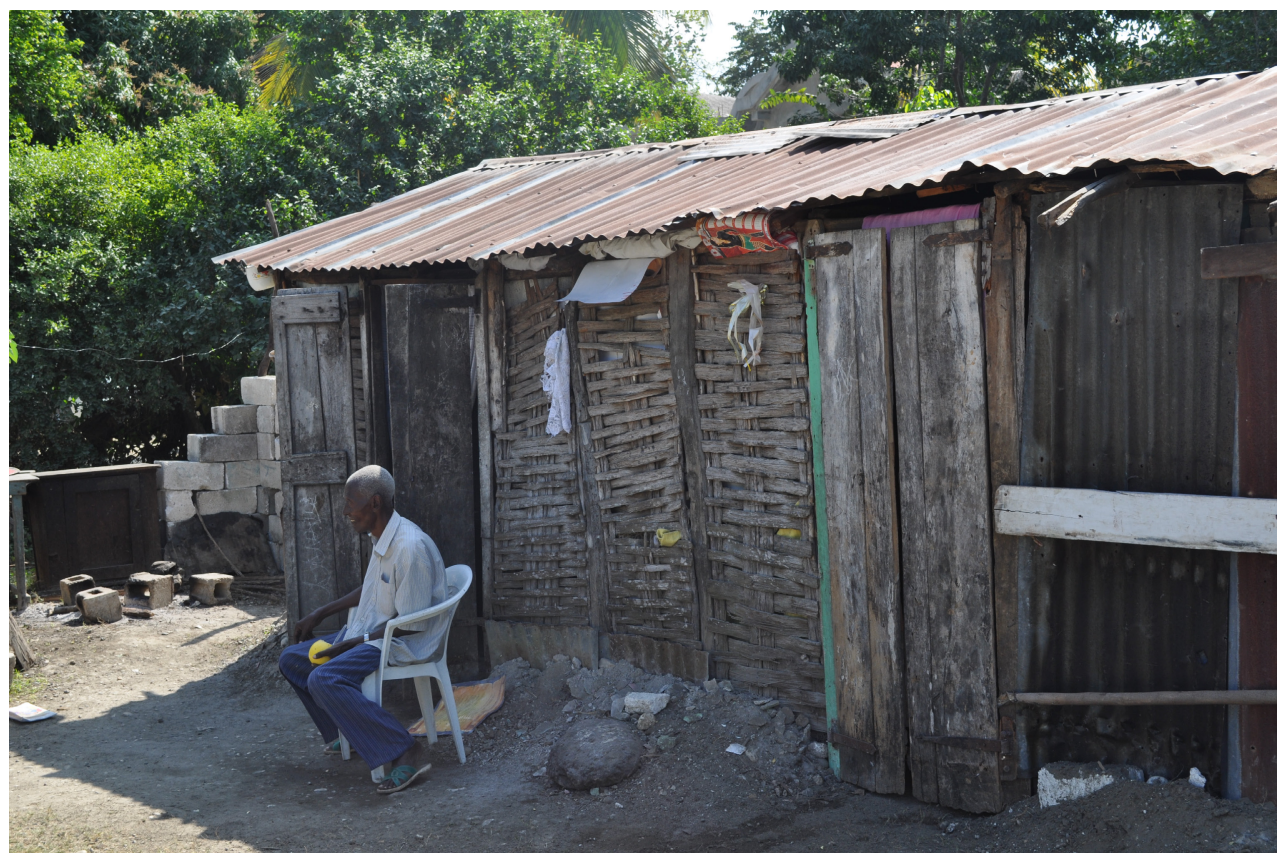

Figure 9. Undamaged light-frame residential building.

In contrast, there were numerous examples of severe damage and collapse to residences with heavy concrete slab floors and roofs (for example, fig. 10). 


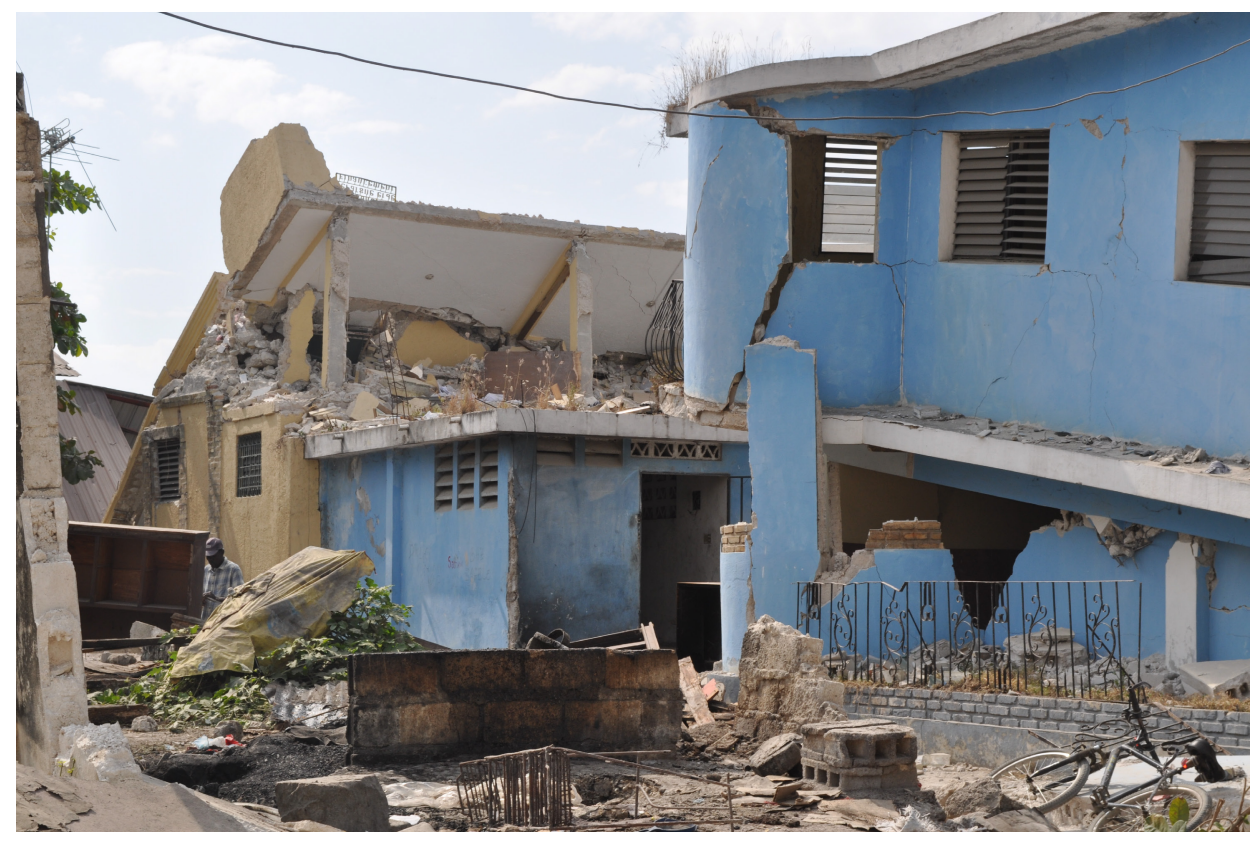

Figure 10. Partial collapse of residential building.

The concrete and masonry buildings have several characteristics that might have contributed to their vulnerability:

- We observed concrete and concrete block being made at several sites. The site materials appeared to be graded on site with a hand sieve to create the aggregate (fig. 11) and mixed on the ground (or in a wheelbarrow) with cement and water to create mortar or concrete mix. It was not unusual to see pockets of loose aggregate in the concrete, indicating a stiff and/or poor mix. The concrete and mortar often appeared to be of poor quality.

- The slabs and roofs were typically about $150 \mathrm{~mm}$ (6 in.) thick and utilized concrete block to create voids in the slabs to reduce the amount of concrete needed. Reinforcing steel was placed between the concrete block void areas to create a system of reinforced ribs in the slab. It appeared that some of this concrete block was placed close to columns, potentially reducing the punching shear capacity of the slab system (fig. 12).

- The supporting concrete columns were typically slender, on the order of 200 to $250 \mathrm{~mm}$ (8 to 10 in.) square. The reinforcing steel in these columns often consisted of only $4 \# 4$ vertical bars with \#2 ties spaced at 200 to $250 \mathrm{~mm}$ ( 8 to $10 \mathrm{in}$.). It was not unusual to see smooth rather than deformed bars as the longitudinal reinforcement. The column ties appeared consistently to be smooth, and the hooks on these ties were short $90^{\circ}$ hooks rather than $135^{\circ}$ seismic hooks (fig. 13).

- The concrete block walls were constructed after the concrete frame had been completed and did not appear to be reinforced. Interior walls were also made with concrete block, further increasing the mass of the residence. 


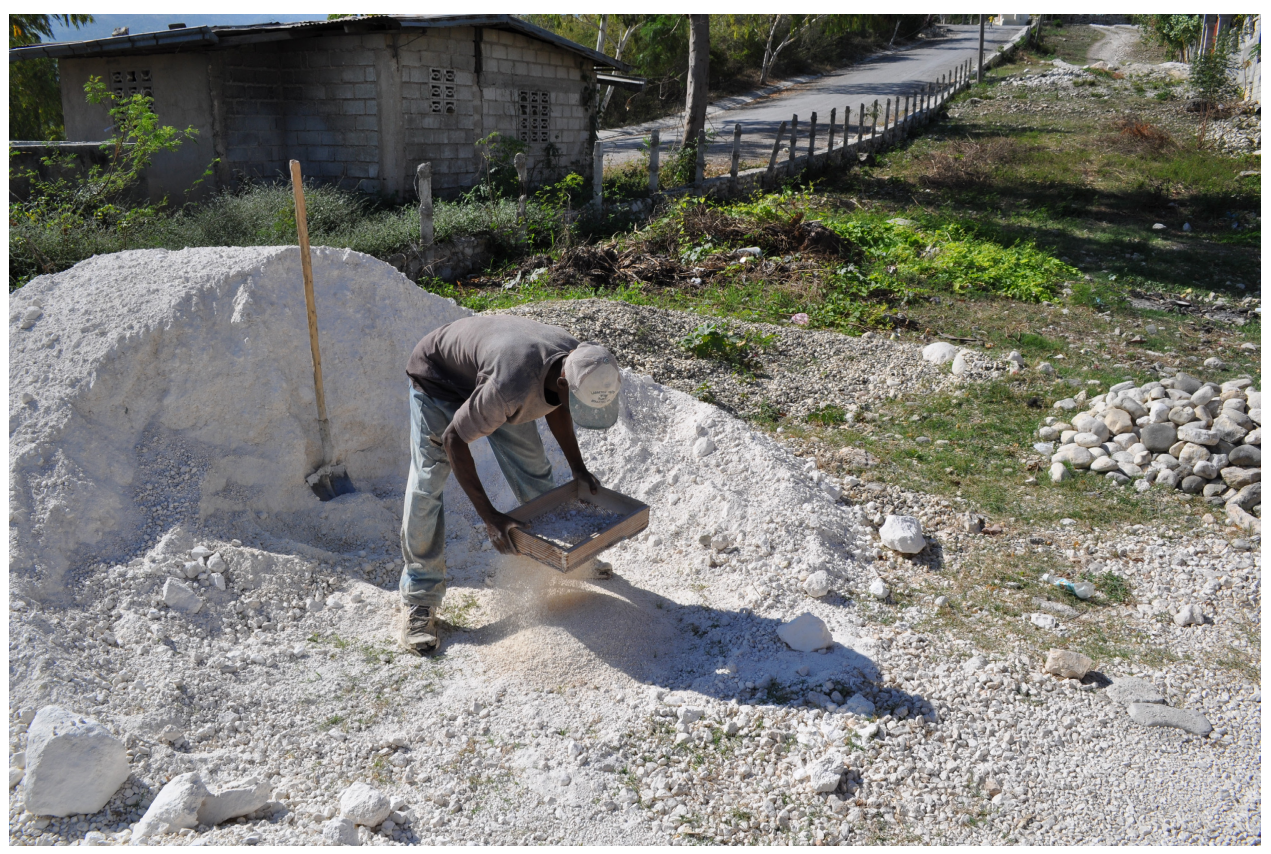

Figure 11. Hand sieving aggregate on site for mortar.

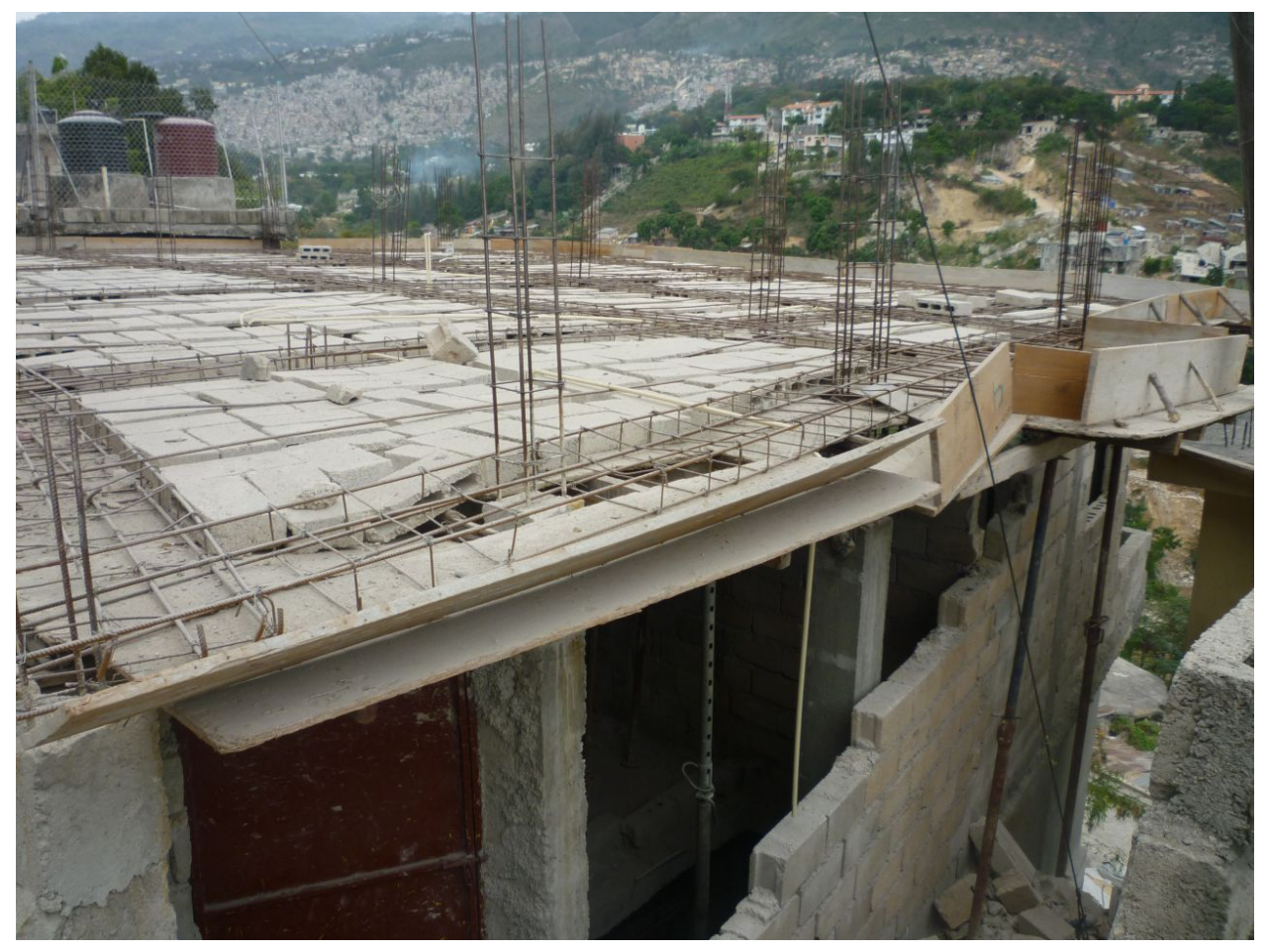

Figure 12. Residential concrete block slab construction. 


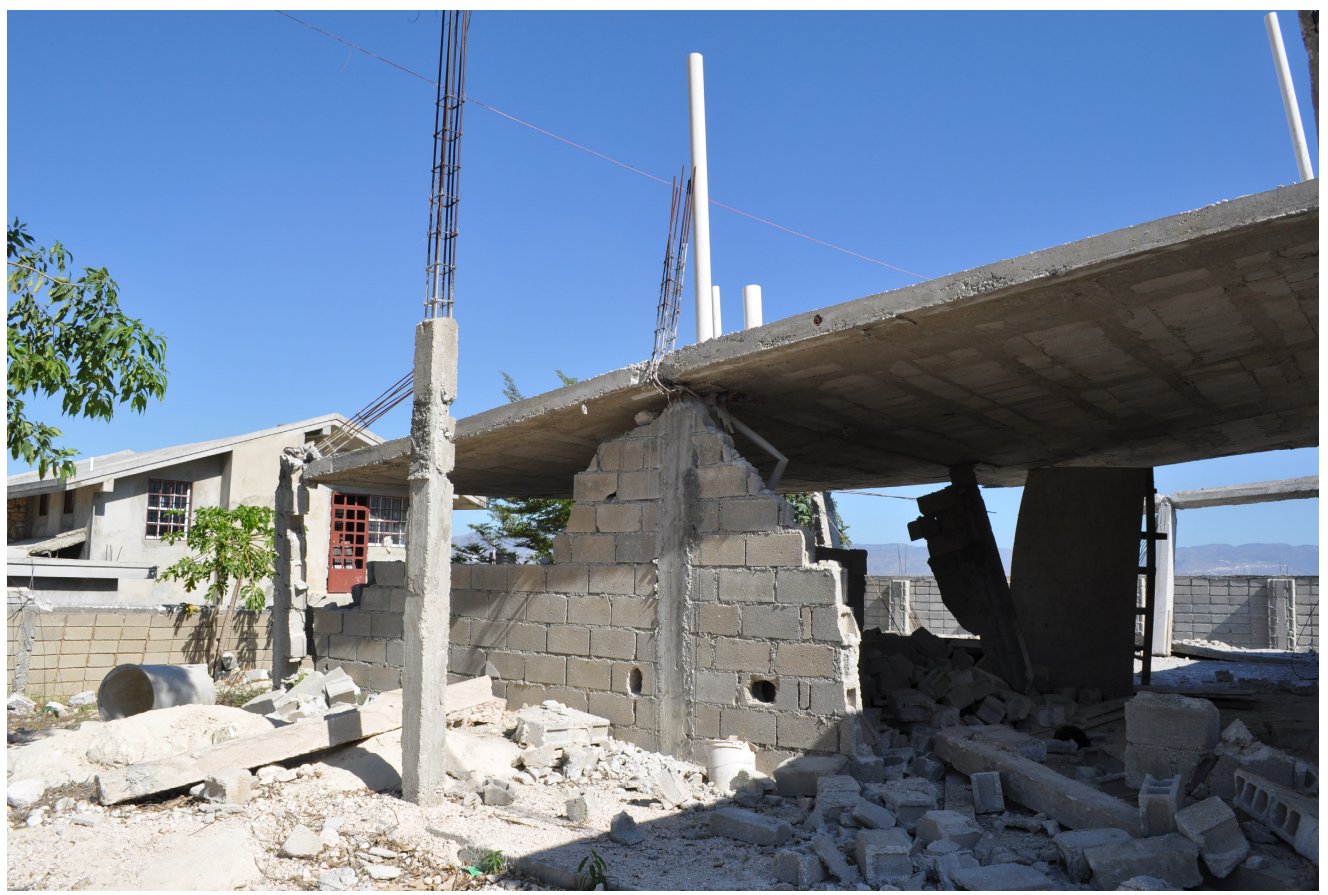

Figure 13. Partial collapse of residential building under construction.

Two adjacent structures located in a hamlet near Léogâne $\left(18.517586^{\circ} \mathrm{N}, 72.572742^{\circ} \mathrm{W}\right)$ illustrate the important benefits of having a low weight, particularly for relatively brittle structures built without consideration of earthquake performance. The first, a two-story, concrete bearing-wall house (constructed by the owner), suffered severe damage to all of its first-story walls, particularly on the sides with multiple openings (fig. 14A). The adjacent, one-story church, with a light-metal roof supported by masonry walls, appeared to be constructed with materials of poorer quality, but it fared much better during the earthquake (fig. 14B).
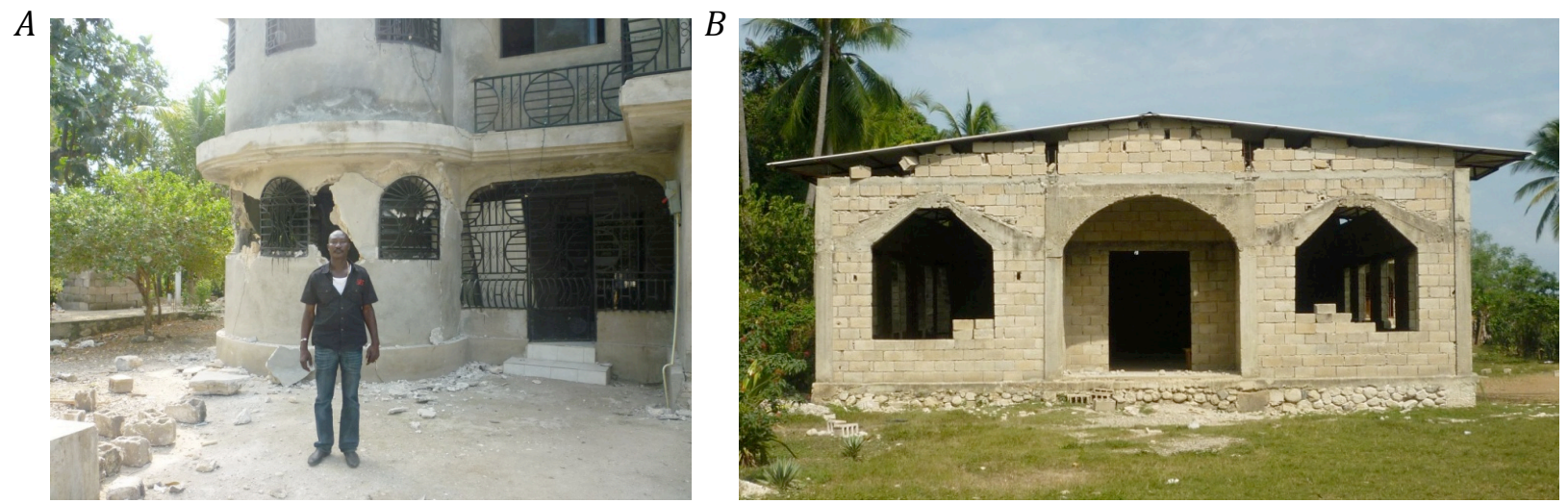

Figure 14. Adjacent rural structures near Léogâne $(A)$ concrete-bearing wall house and $(B)$ church with masonry walls and light-metal roof. 


\section{Multistory Reinforced Concrete and Masonry Structures}

Most multistory structures appeared to consist of reinforced concrete frames, with reinforced concrete roofs and floors, and masonry infill. The team did also find some bearing-wall structures supporting concrete floors and roofs and occasionally, wood or steel roofs. For structures with low to moderate levels of damage, it was often difficult to determine whether the bearing walls were made of concrete, reinforced concrete, or masonry. Only a few of the buildings we observed had any seismic detailing, an observation that is consistent with the observations of Fierro and Perry (2010).

Figure $15 \mathrm{~A}$ shows the collapse of the Turgeau Hospital, whose lateral-force resistance was provided by a reinforced concrete frame with masonry infill. As with numerous other structures we observed, the columns and joints had little transverse reinforcement. The new Digicel building across the street $\left(18.532729^{\circ} \mathrm{N}, 72.323235^{\circ} \mathrm{W}\right)$ appeared to be nearly undamaged, with slight damage to a few windows (fig. 15B). The fundamental period of the Digicel building was likely much larger than that of the apartment building, so the seismic demands would have differed also. Nonetheless, the stark difference in performance suggests that the severe damage to numerous buildings could have been avoided with greater attention to seismic performance.

$A$

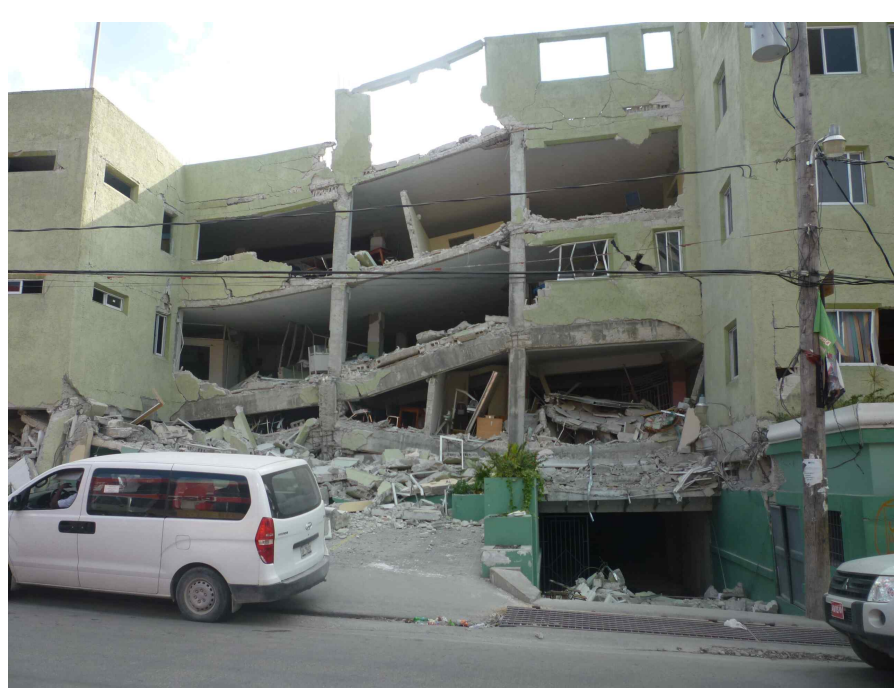

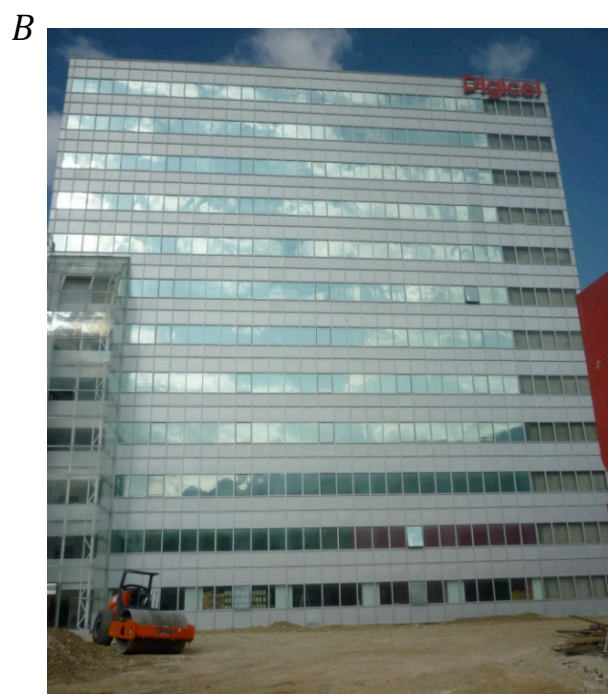

Figure 15. Damage to two structures across the street from one another in Port-au-Prince. $A$, Reinforced concrete frame with masonry infill. $B$, New Digicel building under construction appears to be nearly undamaged.

\section{Case History: Hotel Montana-A Five-Story Reinforced Concrete Hotel}

In 1946 the Estimé government organized a bicentenary celebration of the city of Port-au-Prince. Inspired by the event, Frank Cardozo built Hotel Beau-Site, later renamed Hotel Montana. This hotel $\left(18.517586^{\circ} \mathrm{N}, 72.572742^{\circ} \mathrm{W}\right)$ celebrated its 60th anniversary in 2006 . The original building had 12 rooms; at the time of the earthquake the five-story reinforced concrete hotel had 145 rooms, meeting facilities, and numerous terraces and was known as one of the best hotels in Haiti. The structure was located in the hills of Pétion-Ville and provided beautiful views. The hotel collapsed catastrophically during the earthquake (fig. 16).

Although the Hotel Montana was a high-end property, it appeared to have many of the same vulnerabilities of other concrete construction in Haiti. Heavy, unreinforced concrete masonry walls added weight to the structure but only minimal seismic resistance. Other shortcomings included a lack of ductile 
seismic detailing, a mixture of smooth and deformed reinforcing bars with insufficient hook lengths, and questionable concrete quality (figs. 17, 18, and 19). We obtained samples of concrete and reinforcing steel from the Hotel Montana for later strength testing. Only small portions of the hotel remained intact (fig. 20).

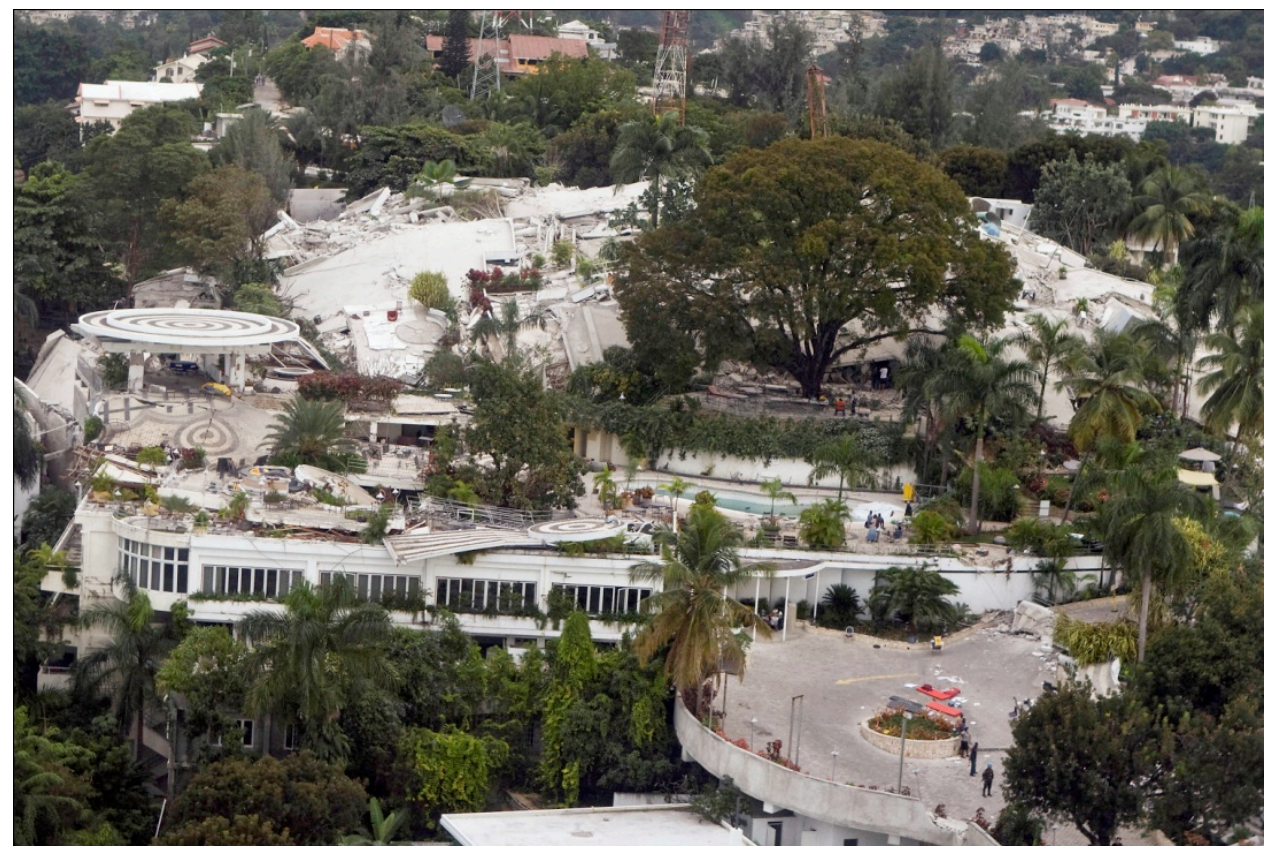

Figure 16. The Hotel Montana in Port-au-Prince on January 13, 2010. (AP Photo/The United Nations, Logan Abassi) 


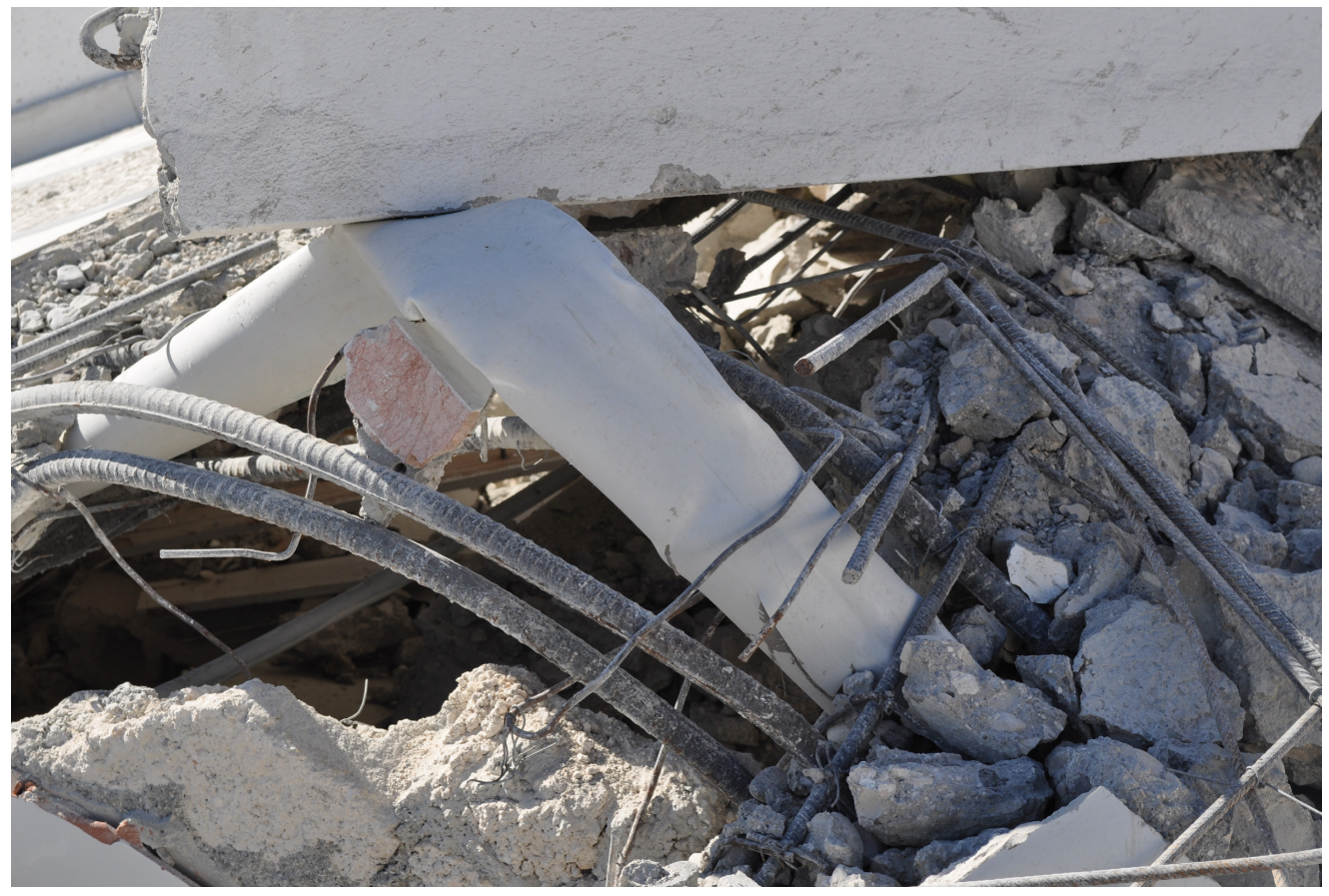

Figure 17. Remains of the top of a column at the Hotel Montana. Note the large embedded PVC pipe and the small \#2 smooth column ties. 

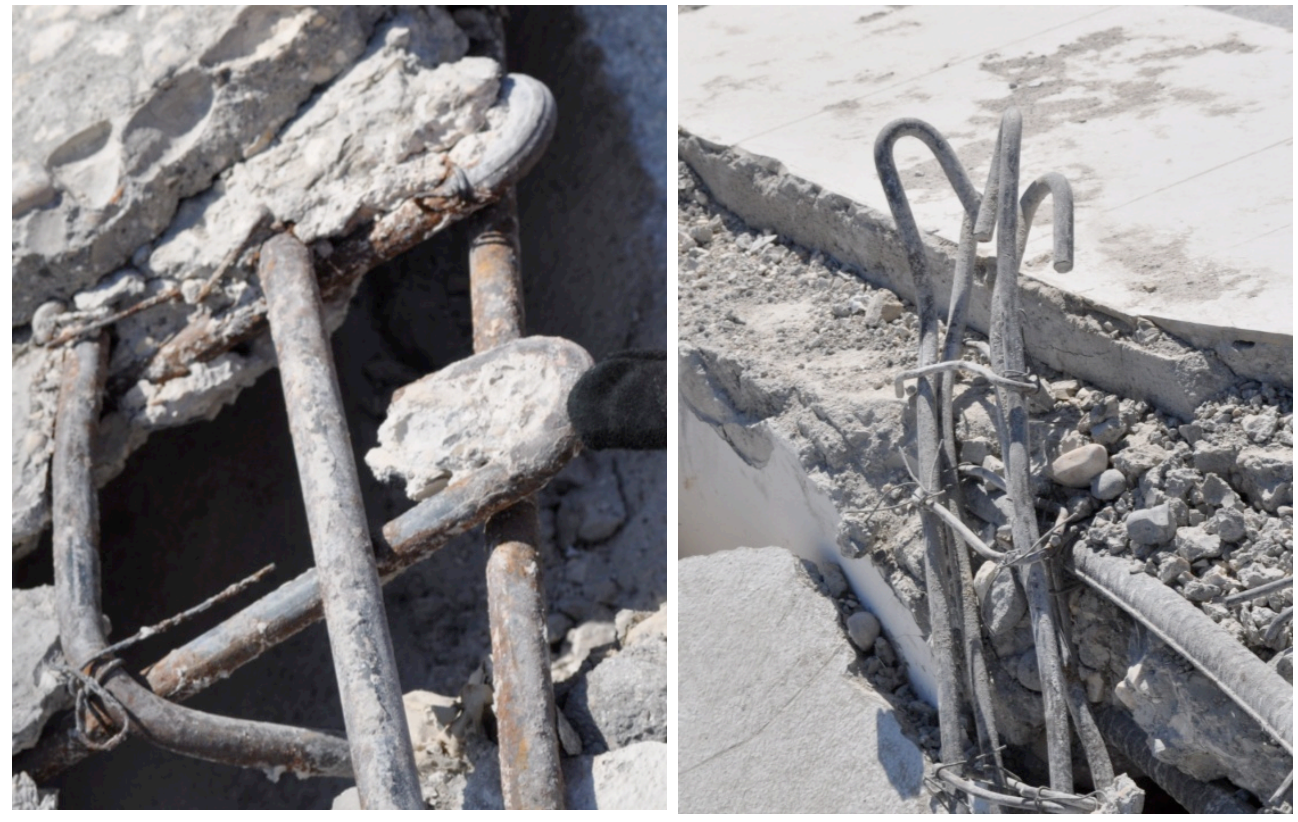

Figure 18. Smooth reinforcing steel was used in both slabs (left) and columns (right) at the Hotel Montana. The hook lengths on reinforcing steel were only 50 to 60 percent of $\mathrm{ACl}$-required lengths. 


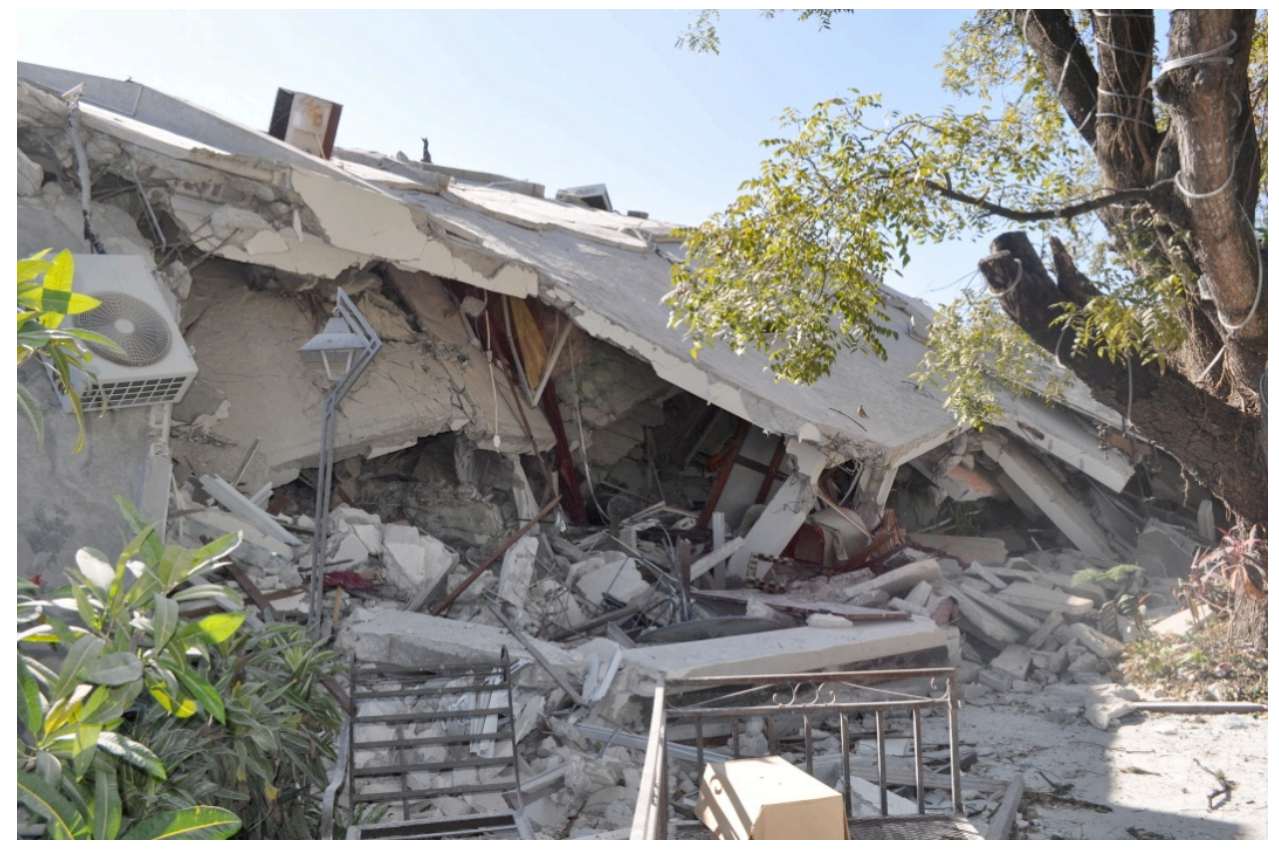

Figure 19. Collapse was extensive throughout the guest wings of the Hotel Montana. It appeared that these wings were constructed of reinforced concrete with unreinforced infill concrete masonry walls.

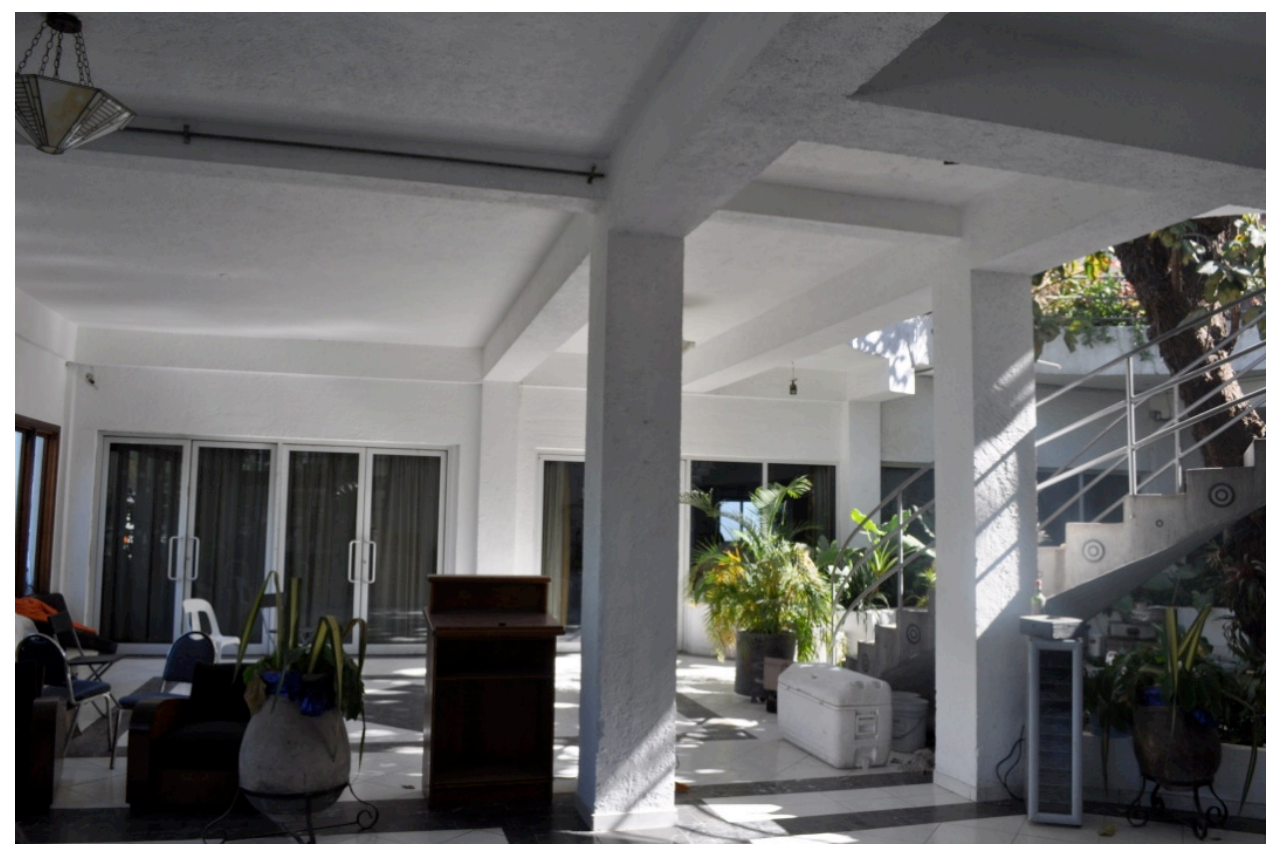

Figure 20. Areas of the Hotel Montana lobby remained intact. It appeared that this region had reinforced concrete beams and slabs without extensive infill walls. 


\section{Case Study: Two-Story Reinforced Concrete Frame with CMU Infill}

The CITS Building at the United Nations Stabilization Mission in Haiti (MINUSTAH) logistics base $\left(18.576971^{\circ} \mathrm{N}, 72.278914^{\circ} \mathrm{W}\right)$ is a two-story structure that appears to be a reinforced concrete frame infilled with masonry. The approximate plan dimensions are $14 \mathrm{~m}$ by $20 \mathrm{~m}$ ( $46 \mathrm{by} 66 \mathrm{ft})$. At the south end, the building is attached to an adjacent building with a light-framed, 34-m (110-ft) span, steel-trussed arch structure (fig. 21). The building was used by the United Nations (UN) to house IT services and for storage.

On the north side, the structure had diagonal cracks up to $6 \mathrm{~mm}(1 / 4 \mathrm{in}$.) wide across the walls and columns at the first floor between window penetrations on the north wall (fig. 22). The north face appeared to have a residual displacement of about $3 \mathrm{~mm}(1 / 8 \mathrm{in}$.) to the east. On the northwest side of the structure, one of the columns had a residual flexural crack $(3 \mathrm{~mm}, 1 / 8 \mathrm{in}$.) at its base. Only minor cracking was observed on the east and west walls. The south wall, which was solid, showed minimal signs of damage. Similarly, the interior columns and walls showed little distress.

This damage pattern and building geometry are consistent with a building responding torsionally during the earthquake. The north end (with its multiple penetrations) deformed much more (and had more damage) than the south end with its solid wall. Figure 23 is an interior close-up of the center column crack showing that the material in the column feature is the same as the masonry cover coat, indicating continuity of the wall. Based on this evidence, it is possible that the structure consists of interior concrete columns, possibly reinforced, and exterior unreinforced load-bearing masonry walls. Because of the shear cracking on the north side of the building, the building was evacuated.

The attached steel-arch warehouse structure performed well. The only damage was non-structural; portions of $1.5-\mathrm{m}(5-\mathrm{ft})$ tall concrete protective wall sections around the interior perimeter tipped over. The other building attached to the steel-arch warehouse (on the left side in fig. 21), which appears to be of the same construction as the CITS Building, experienced similar damage to the exterior wall.

This example suggests that structures could survive the earthquake with little damage, even without seismic detailing, as long as the walls were large enough and had few penetrations. 


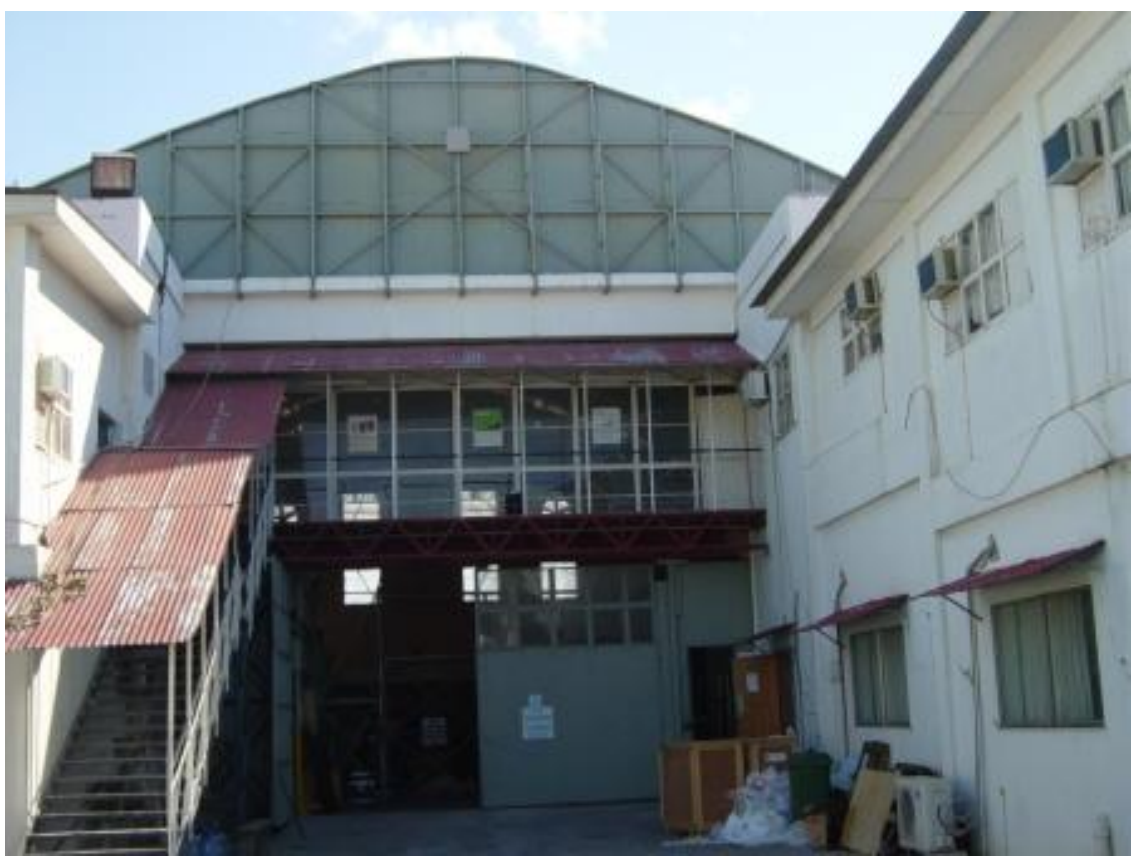

Figure 21. Two-story CITS Building (on right) attached to steel arch structure (in background).

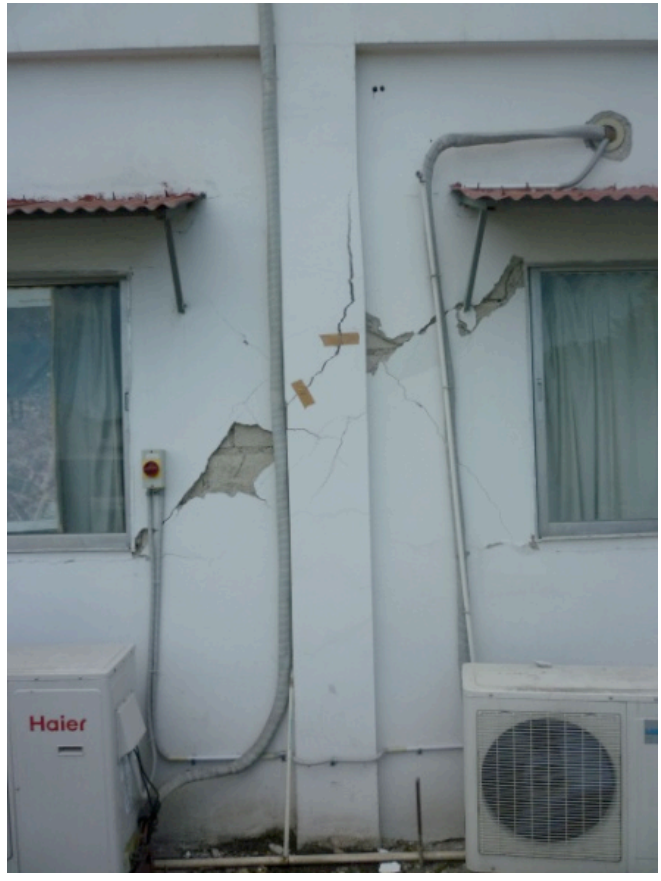

Figure 22. Exterior-wall cracking of the first floor of the CITS Building. 


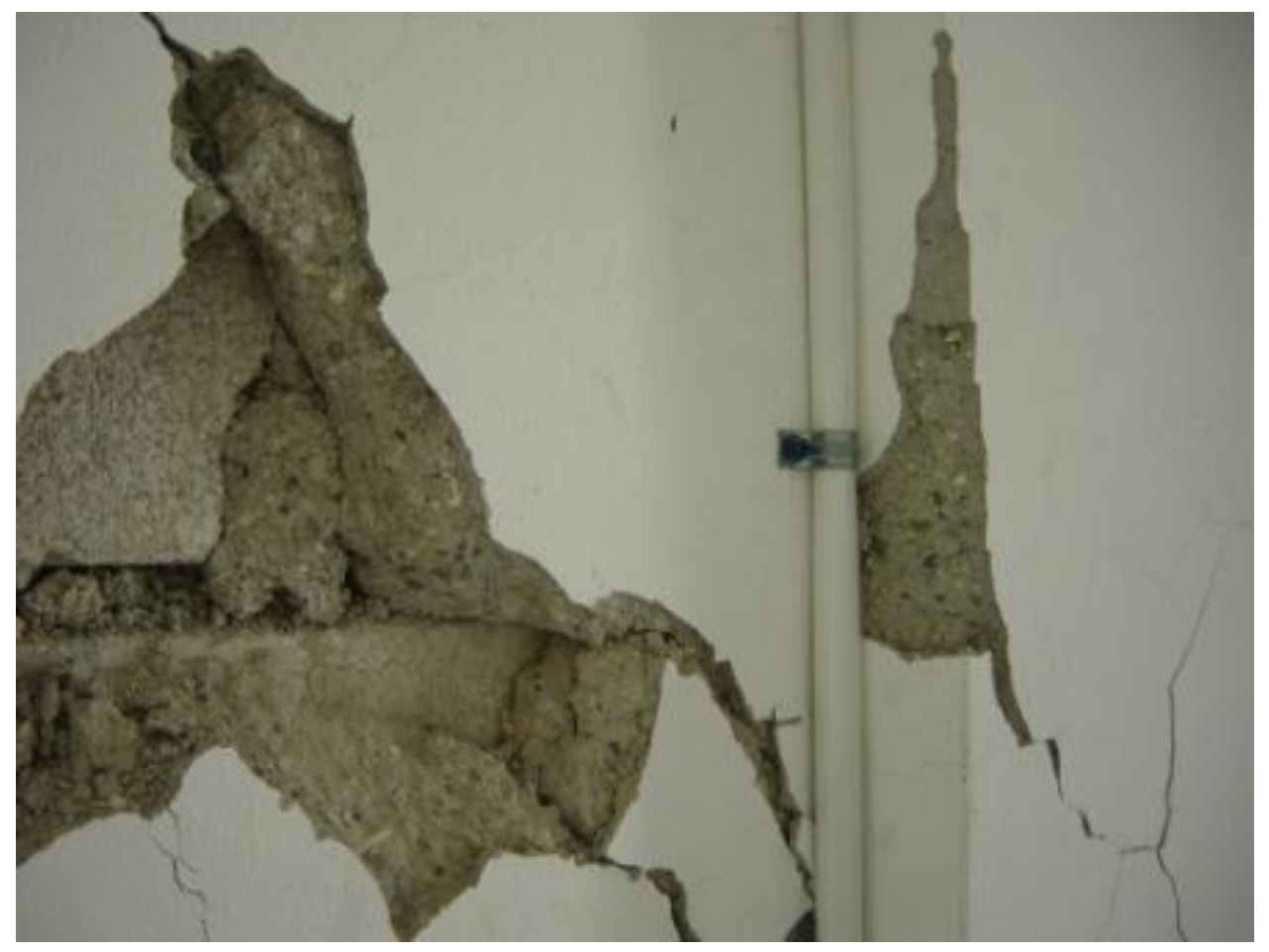

Figure 23. Interior close-up view of wall crack at the CITS Building.

\section{Case Study: 4-5-Story Reinforced Concrete Frame Under Construction}

The UNIH University Building $\left(18.528299^{\circ} \mathrm{N}, 72.575516^{\circ} \mathrm{W}\right)$ was located along Nationale No. 2 about $6.2 \mathrm{~km}$ (3.75 miles) east of the city of Léogâne. At the time of the earthquake, this building had not yet been completed; it was three stories tall with column reinforcing steel sticking out of the top deck for a fourth floor. The site had no signs of recent construction activity, suggesting that construction may have been interrupted before the earthquake. The concrete-frame building collapsed catastrophically, with the upper stories moving several feet to the east relative to the base (figs. 24 and 25). This example illustrates the inadequacy of the bare reinforced concrete frame, with its flexible stories.

The building was relatively simple and repetitive in plan, measuring approximately $18.6 \mathrm{~m}$ (61 feet) wide (three $5-\mathrm{m}[16.5-\mathrm{ft}]$ bays with a $1.8-\mathrm{m}[5.75-\mathrm{ft}]$ cantilever at each end) by $48.2 \mathrm{~m}(158 \mathrm{ft})$ long (nine $5-\mathrm{m}[16.5-\mathrm{ft}]$ bays with a $1.8-\mathrm{m}[5.75-\mathrm{ft}]$ cantilever at each end). The structural floor framing included a grid of 250 by $350 \mathrm{~mm}$ (10 by 14 in.) beams in each direction supporting a slab 125 -mm ( 5 -in.) thick. The typical columns were only 250 by $250 \mathrm{~mm}$ (10 by $10 \mathrm{in}$.) in cross-section.

The reinforcing steel for both the columns and beams was minimal, with a combination of smooth and deformed reinforcement (figs. 26 and 27). The longitudinal reinforcement in the columns typically consisted of four $\# 4$ or $\# 5$ bars (fig. 26). The transverse column reinforcement appeared to consist of smooth \#2 bars spaced at 200 to $230 \mathrm{~mm}$ (8 to 9 in.). The structure had little (if any) maso dnry in place at the time of the earthquake, but a stack of CMUs adjacent to the structure suggests that infill was to be added later. An ETABS model of the building (fig. 28) indicated that the structural frame would have been adequate for gravity loads but would have been highly overstressed for lateral seismic loads. 


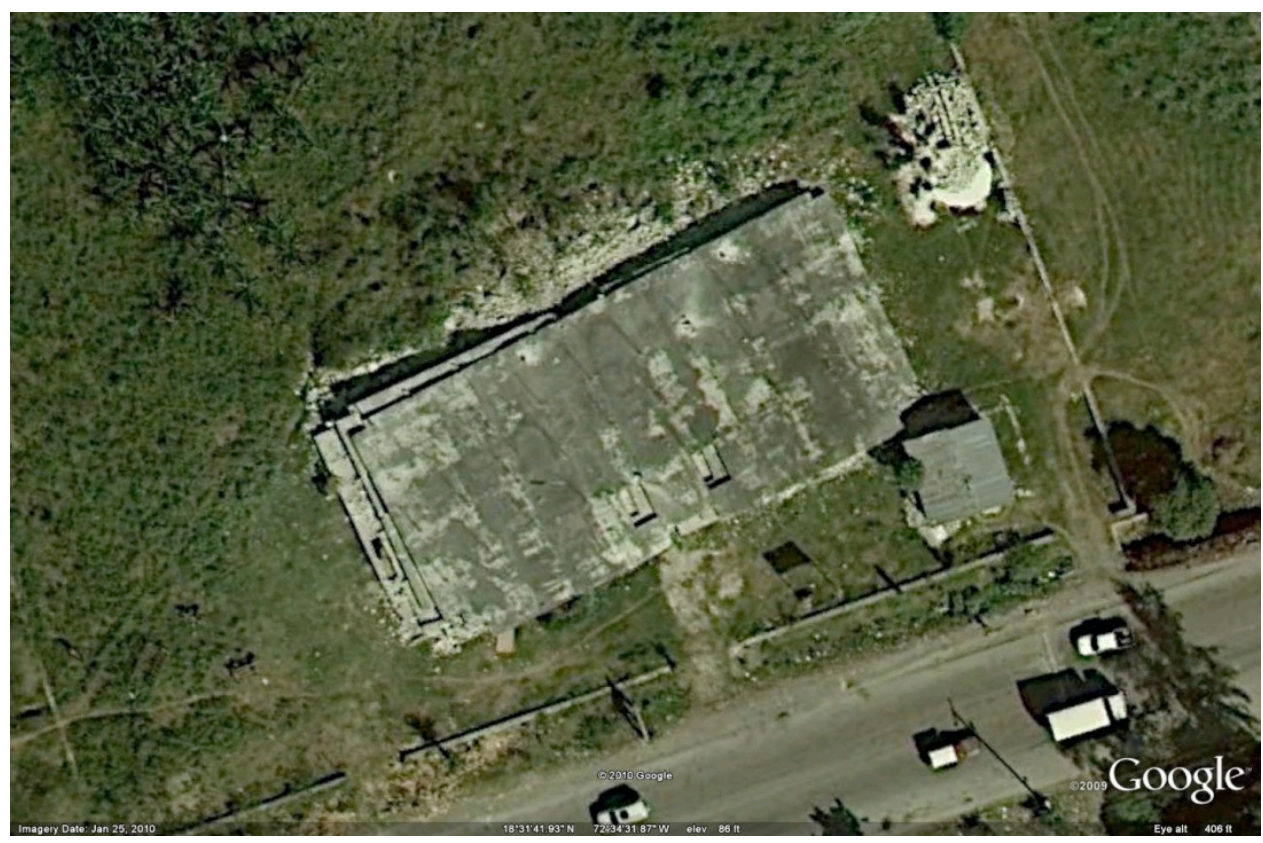

Figure 24. Aerial view indicating that the UNIH University Building under construction rotated slightly and moved to the east as it collapsed. (Google Earth)

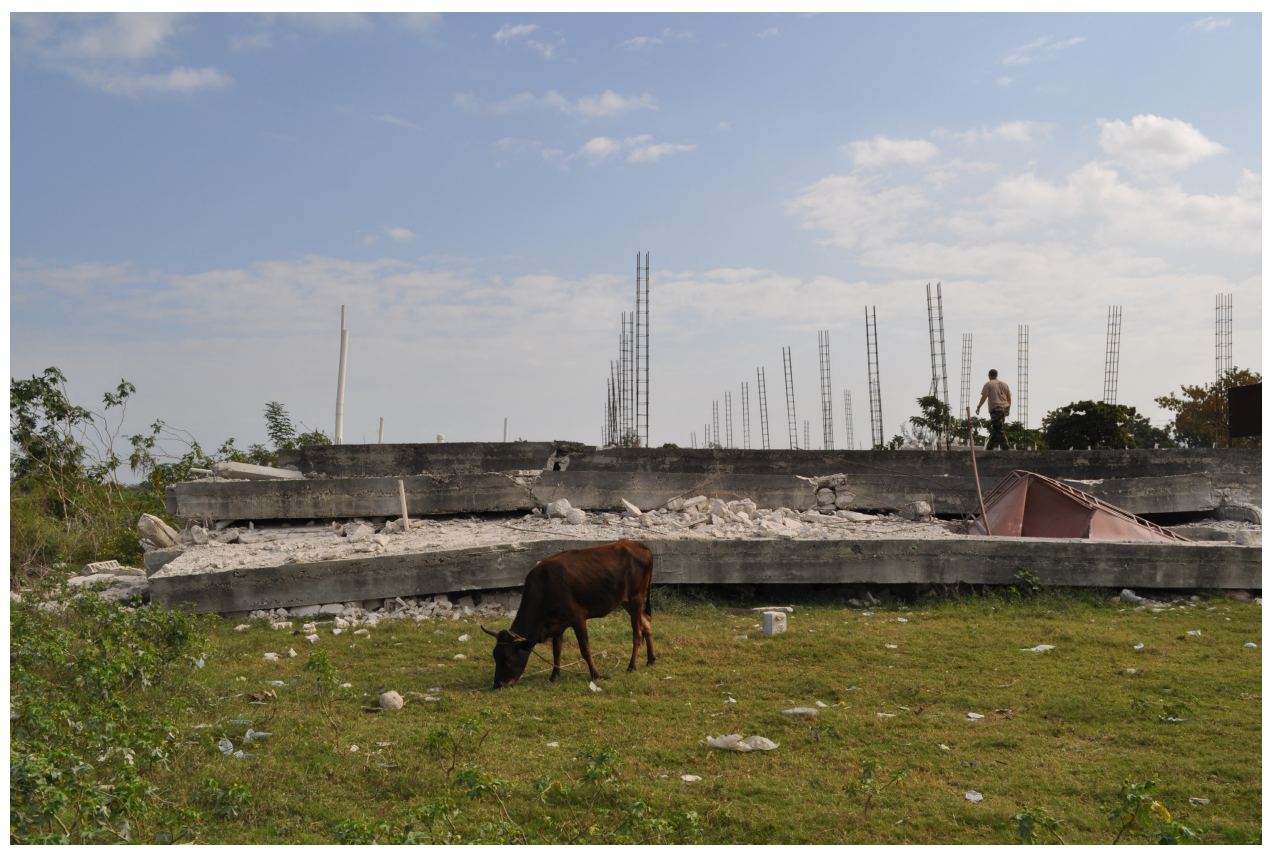

Figure 25. A view from the west side of the UNIH University Building under construction indicates that there was movement to the east (approximately half the height of the columns) during the collapse. 


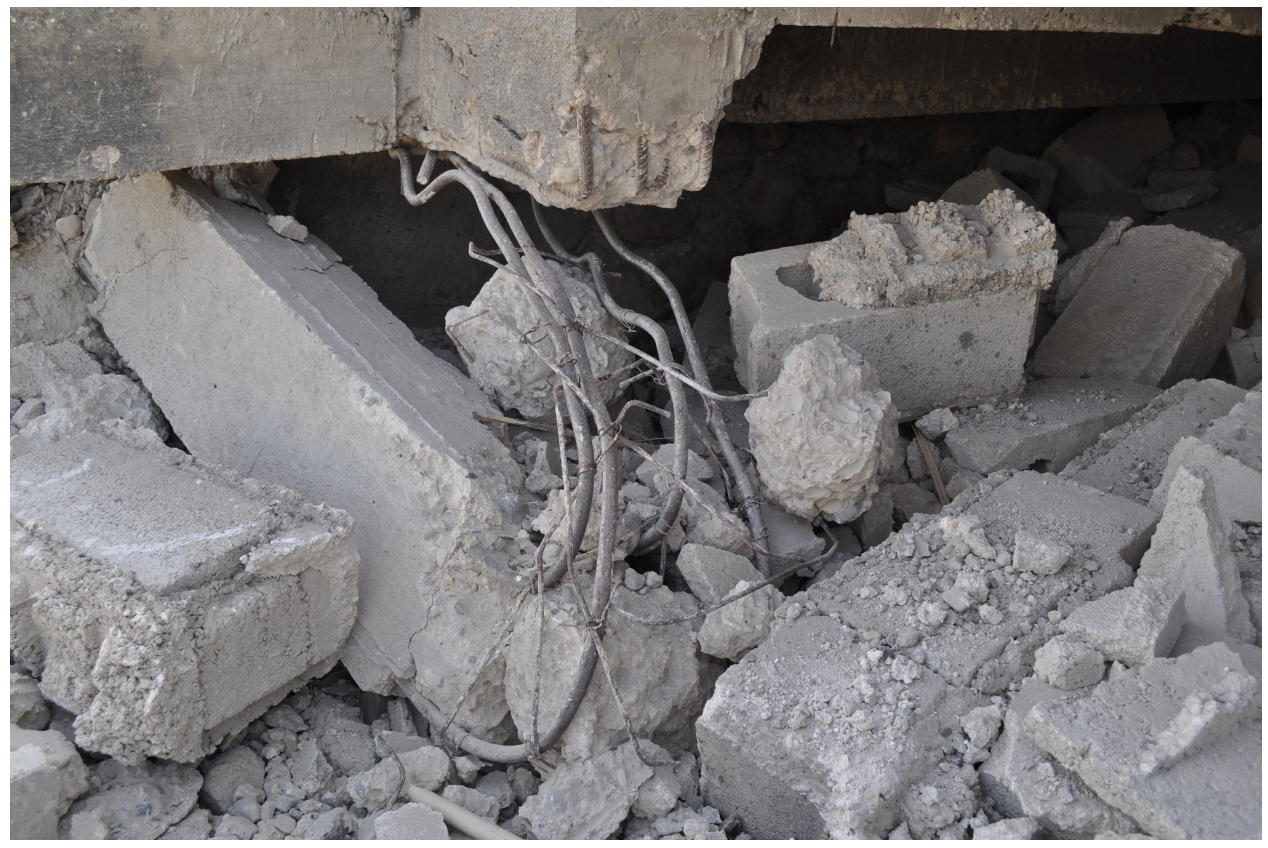

Figure 26. Smooth reinforcing steel and minimal column ties were evident in some of the collapsed columns at the UNIH University Building.

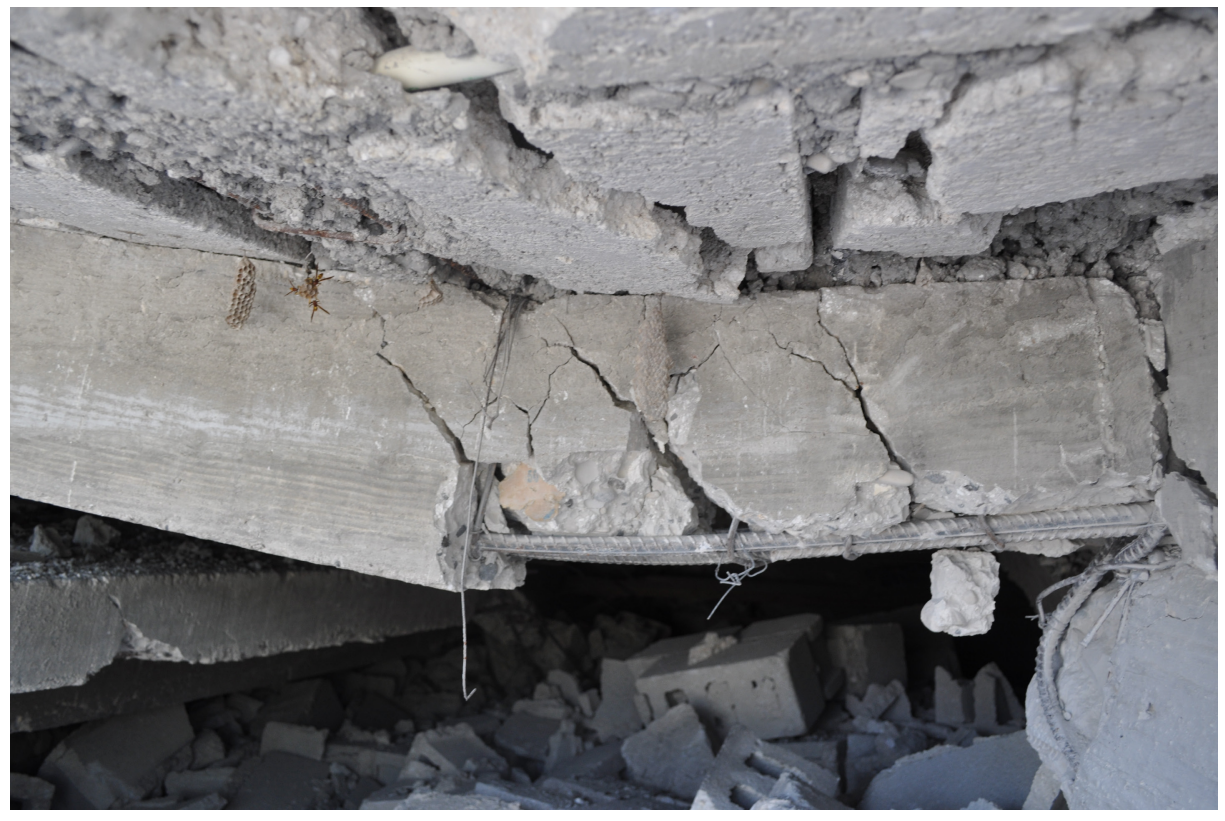

Figure 27. Failure in one of the structure's beams at the UNIH University Building. 


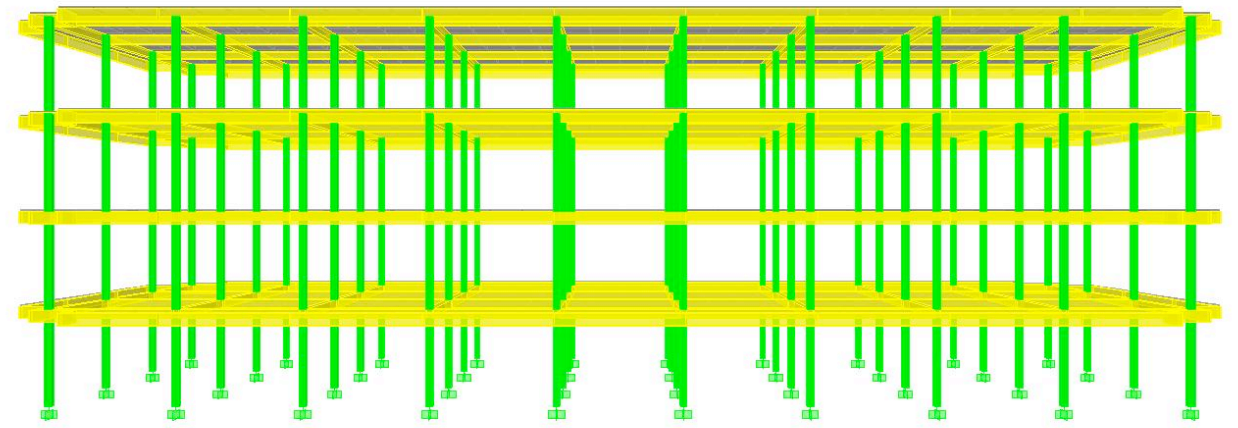

Figure 28. ETABS model of UNIH University Building at full height (four floors). (Source: Baldridge \& Associates Structural Engineering, Inc.)

\section{Case Study: Moment-Frame Buildings Designed for Earthquake Resistance}

The Union School in Port-au-Prince provides an interesting case study, because the structural drawings were available and indicated that the structures were intended to conform to the provisions of American Concrete Institute (ACI) Building Code 318-99. These buildings are important to the U.S. State Department, because many children of the U.S. Embassy staff attended the school.

The school complex consisted of two three-story buildings: the elementary school building (fig. 29A) and the learning center. The lateral resistance of both buildings was provided by moment frames arranged on rectangular grids without setbacks or column offsets. Most of the bays were infilled with concrete masonry units (CMU) with some vertical reinforcement, but the masonry did not appear to be attached to the reinforced concrete frame. The drawings called for regions of weaker blocks between the CMU and the adjacent columns and beam above, but there was no evidence that this design feature was implemented during construction.

During the earthquake, the infill panels were damaged in numerous locations throughout the buildings. The damage to the masonry was dominated by in-plane diagonal shear failure of panels (fig. 29C). We did not see many examples of out-of-plane wall instability, possibly because the walls appeared to be reinforced vertically.

The column damage in the two buildings differed greatly. In the learning center, the columns of the first and third stories appeared to be undamaged. In contrast, nearly all of the columns in the second story failed in shear over the middle third of their height (fig 29B). This region coincided with the region of wider hoop spacing (about $200 \mathrm{~mm}$ or $8 \mathrm{in}$.) specified on the structural plans (fig. 29E). The deformation demands for these columns were likely low, because none of the ends of these columns (where the hoop spacing was closer to $100 \mathrm{~mm}$ or $4 \mathrm{in}$.) had signs of flexural spalling.

In the elementary school building, the columns of the second and third stories were undamaged, but there was some shear damage in several columns in the relatively flexible first story, which had a larger story height and fewer masonry walls than the upper stories. The damage was greatest in two "captive" columns whose deformation was restrained by partial-height masonry walls (fig. 29D). As with the learning 
center, there was no evidence of flexural damage, suggesting that the shear failures occurred at relatively low levels of deformation.

The apparently low levels of deformation suggests that buildings subjected to similar ground motions would have suffered little structural damage had they been designed and constructed to resist earthquakes. 

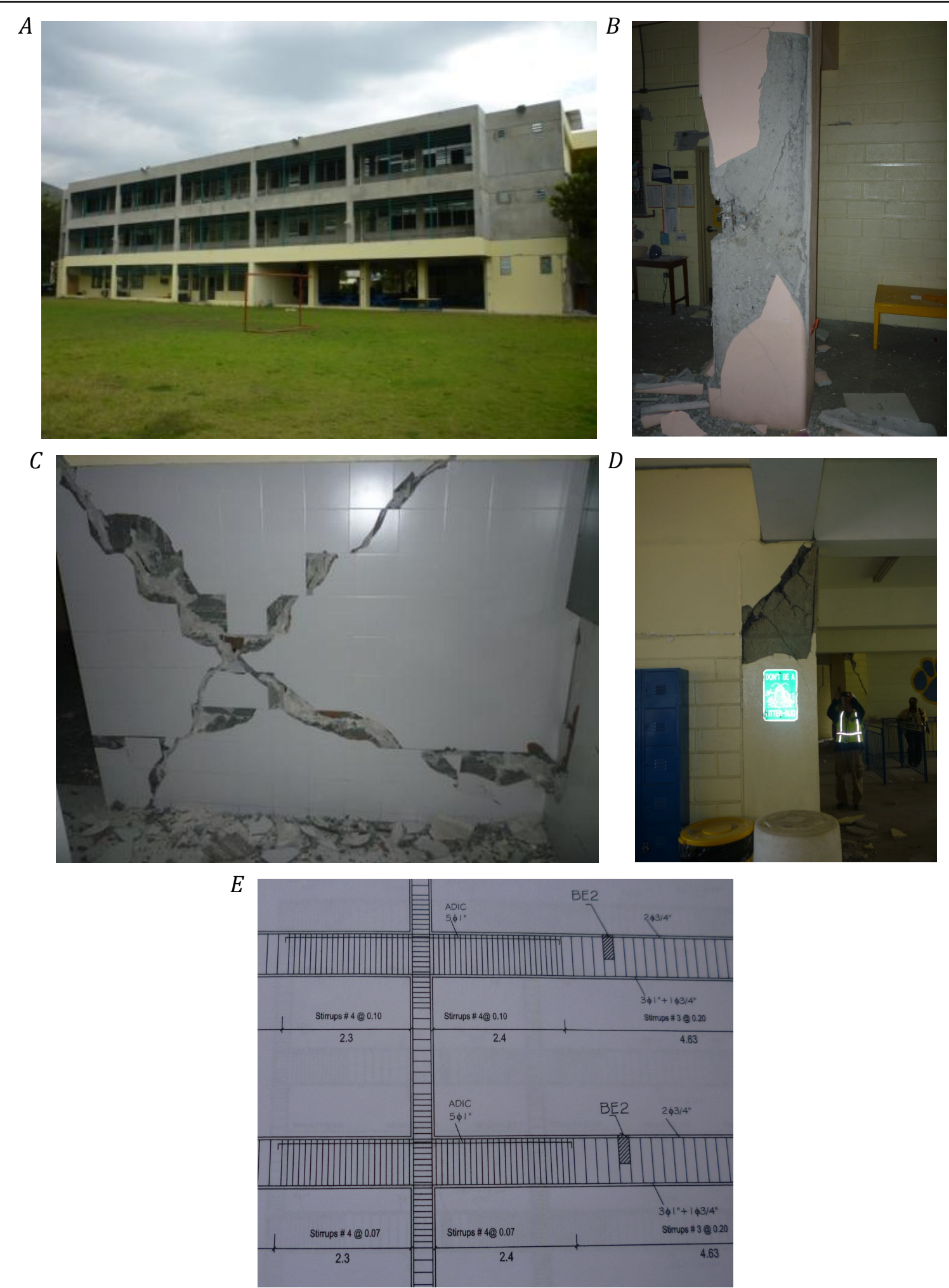

Figure 29. Union School in Port-au-Prince. $A$, Elementary school building. $B$, Shear failure of 2 nd story column (learning center). $C$, Shear failure of masonry infill. $D, 1$ st-story captive column (elementary school). $E$, Structural detail for second story column. 


\section{Pre-Engineered Metal Buildings}

Pre-engineered metal buildings (PEMB) are not common in Haiti. Over the course of our reconnaissance, we saw fewer than 15 . The PEMB structures we observed had unreinforced masonry walls rather than light-gauge metal siding, which is more typical in the United States. For warehouse or industrial structures in Haiti, the common structural configuration included reinforced concrete columns with masonry infill walls supporting steel trusses and a light-gauge metal roof. While some industrial or warehouse structures with concrete and masonry bearing walls experienced partial or total roof collapses, the PEMB structures fared much better. The steel framing supporting the gravity loads for the most part appeared undamaged. A PEMB with metal siding located at the port in Port-au-Prince was an exception to this general observation. The significant amount of lateral spreading and impacts of toppled shipping containers caused some of the steel frames to fail.

A negative aspect of the performance of the steel-framed structures was the detachment of the nonstructural masonry. The extent of the resulting damage varied. In one case, the failure of the masonry caused the roof below to collapse. Figures 30 and 31 show two typical examples of PEMB structures in Port-au-Prince in which the masonry failed out of plane. We saw no evidence of ties between the structural steel and the masonry walls.

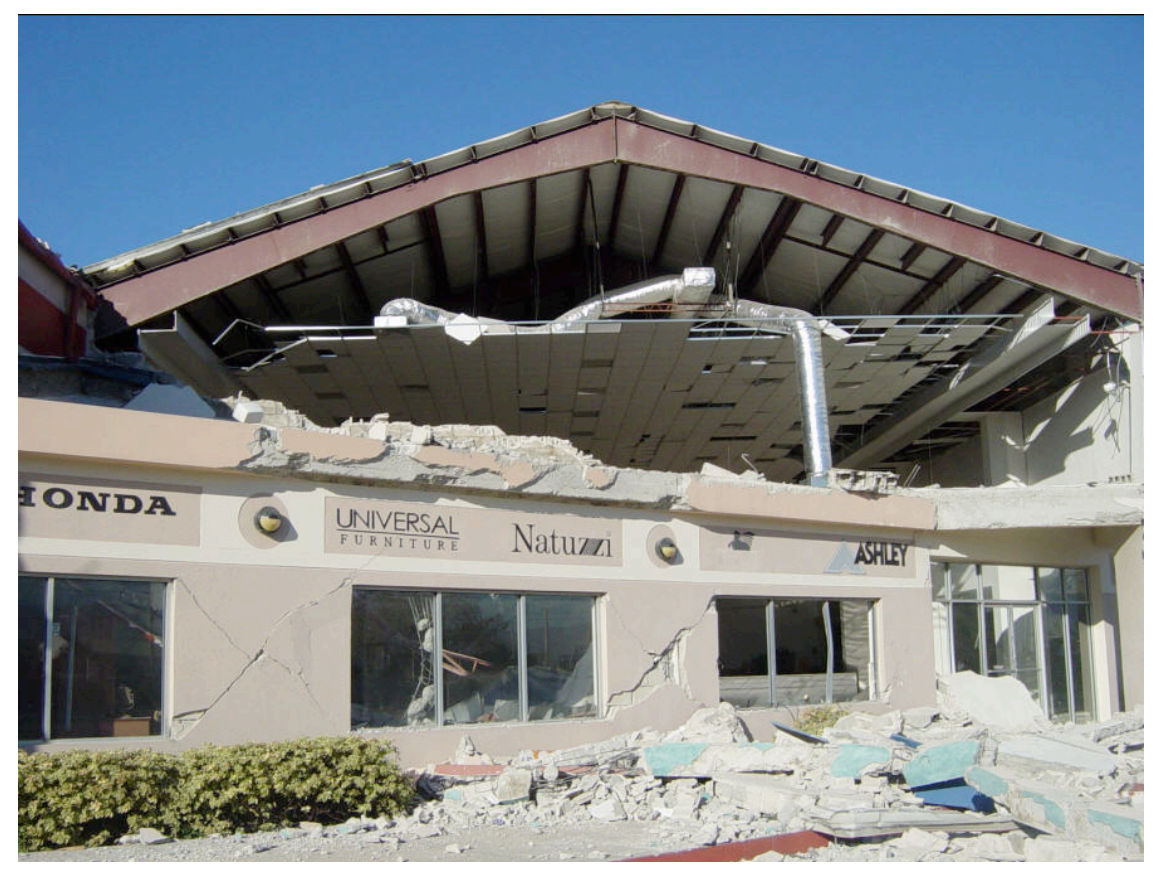

Figure 30. Infill masonry wall collapse of PEMB, Port-au-Prince. 


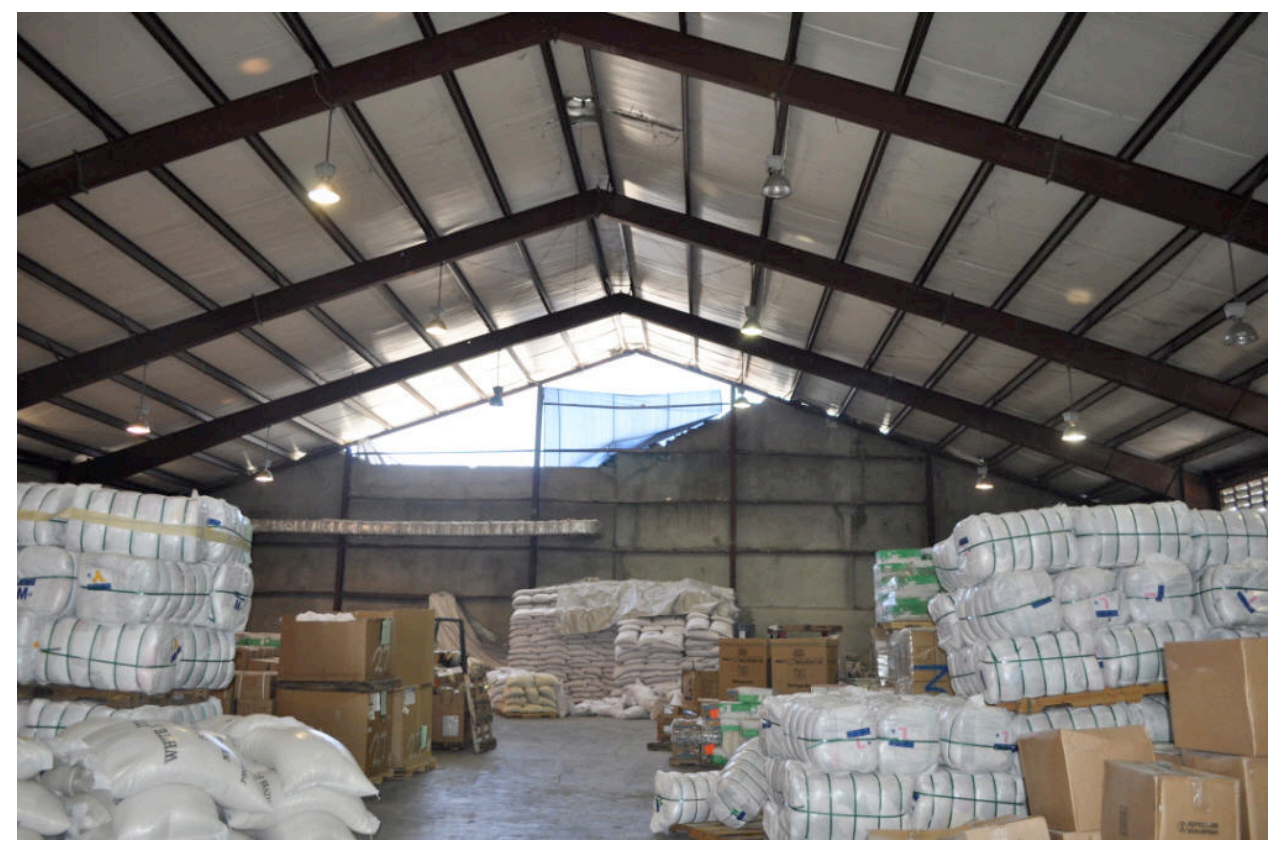

Figure 31. Infill masonry wall collapse of PEMB, Port-au-Prince.

\section{Nonstructural Damage}

The structural damage was accompanied by numerous instances of nonstructural damage, some of which posed significant hazards.

- Figure 30 shows in-plane failure of the masonry infill. Even without the failure of the columns, the widespread failure of the masonry infill alone would have been costly and would have led to long interruptions to the function of the school.

- Figure 31 shows the out-of-plane failure of a warehouse masonry façade. This failure exposed the interior of the building to the elements, and because of the large amount of failed material, posed a hazard to people near the façade.

- Figure 32 shows one of the consequences of moving into new buildings to escape damage in other buildings. The heavy boxes are precariously positioned above one of the relocated workers from the CITS Building. 


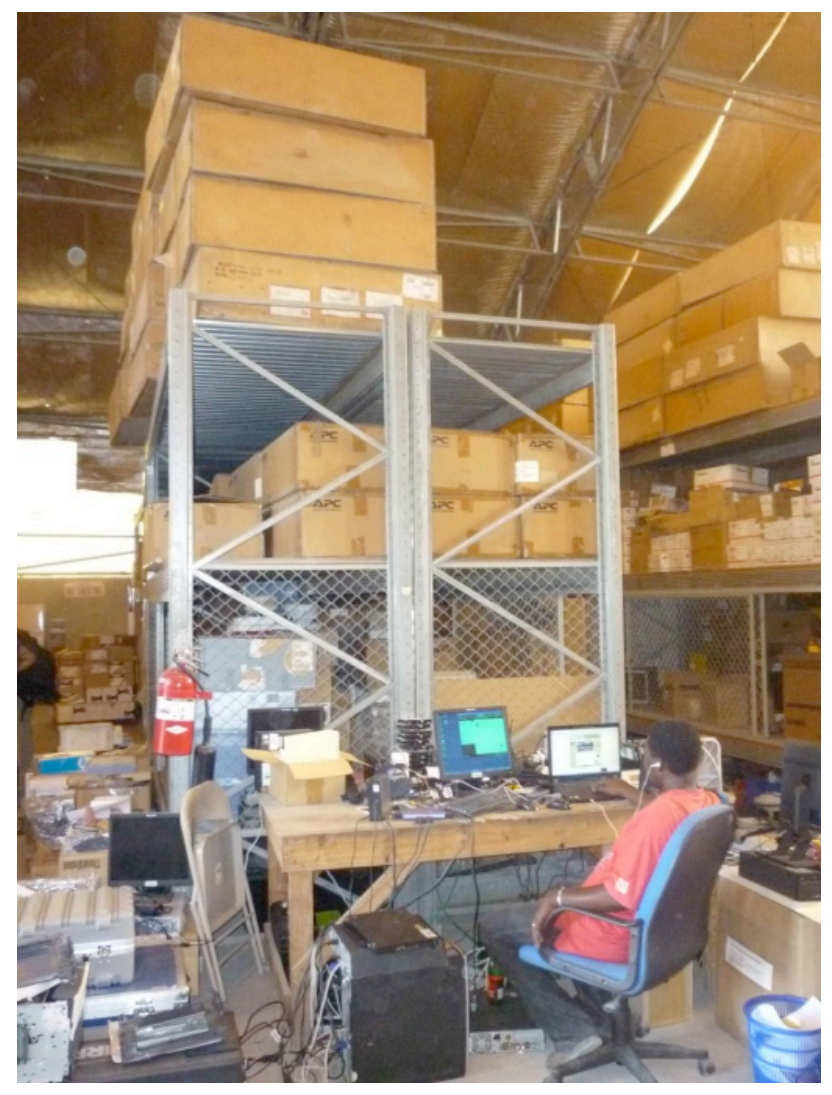

Figure 32. Heavy boxes are perched precariously above a worker who had been displaced by damage to the CITS building.

The importance of nonstructural damage can be illustrated with the example of a hospital in Port-auPrince.

- As shown in figure 33, the power lines and transformers were located over and directly adjacent to the diesel fuel tank.

- The diesel fuel tank for the generators was not tied down to its supporting concrete foundation pedestals (fig. 34).

- The power pole with its heavy transformers moved during the earthquake and is now leaning. The extent of the residual movement is shown in figure 35.

- A nearby nonstructural wall is leaning towards occupied office space (fig. 36). 


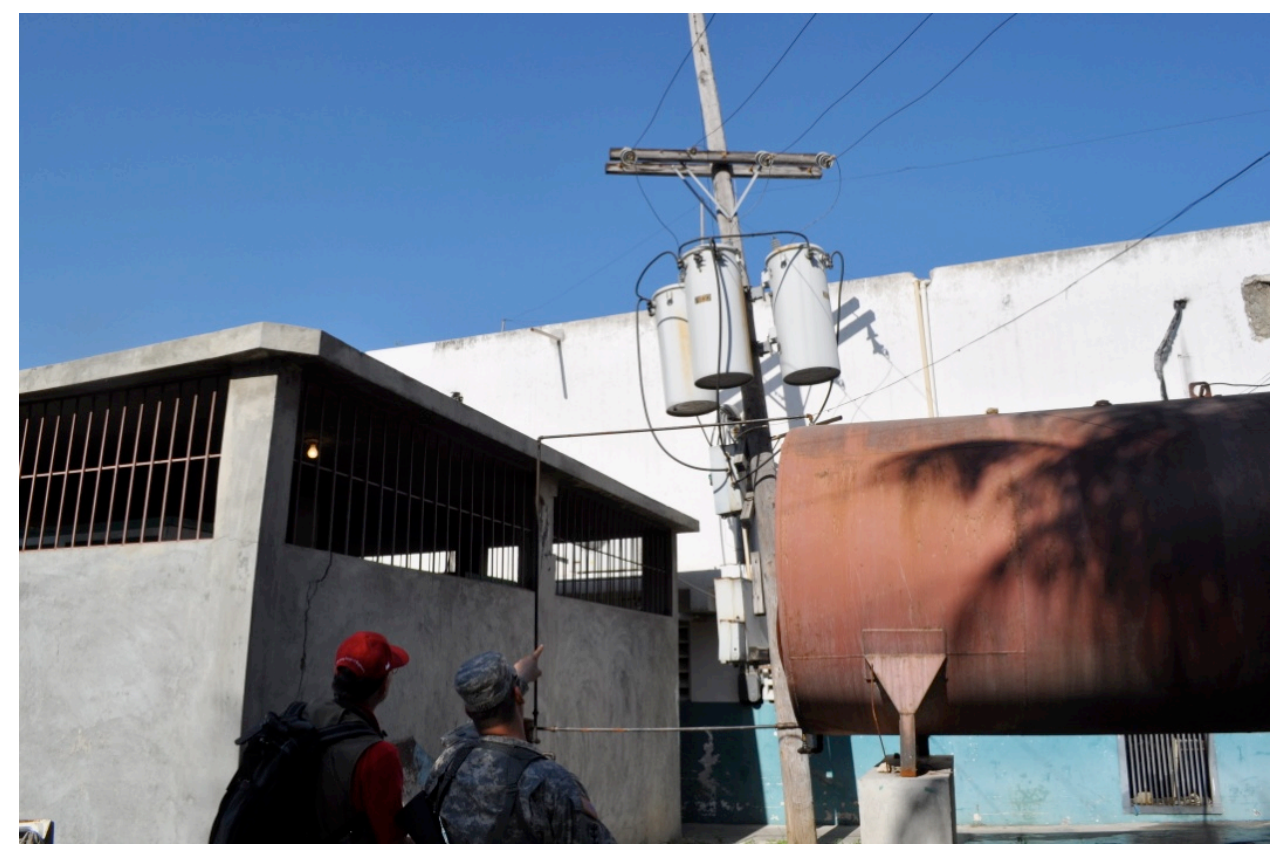

Figure 33. Hospital emergency power system, generator room and fuel tank.

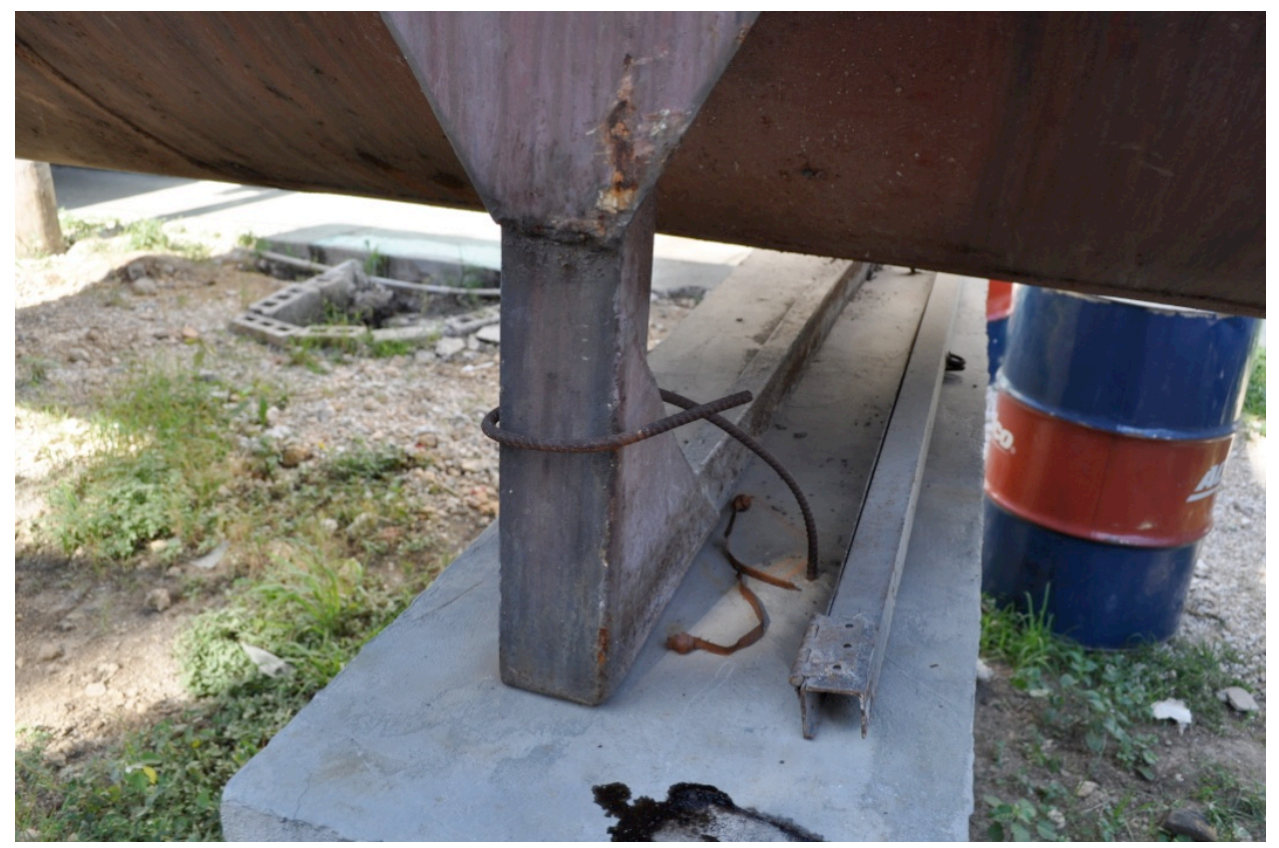

Figure 34. Fuel tank at hospital is not tied to its pedestal foundation. 


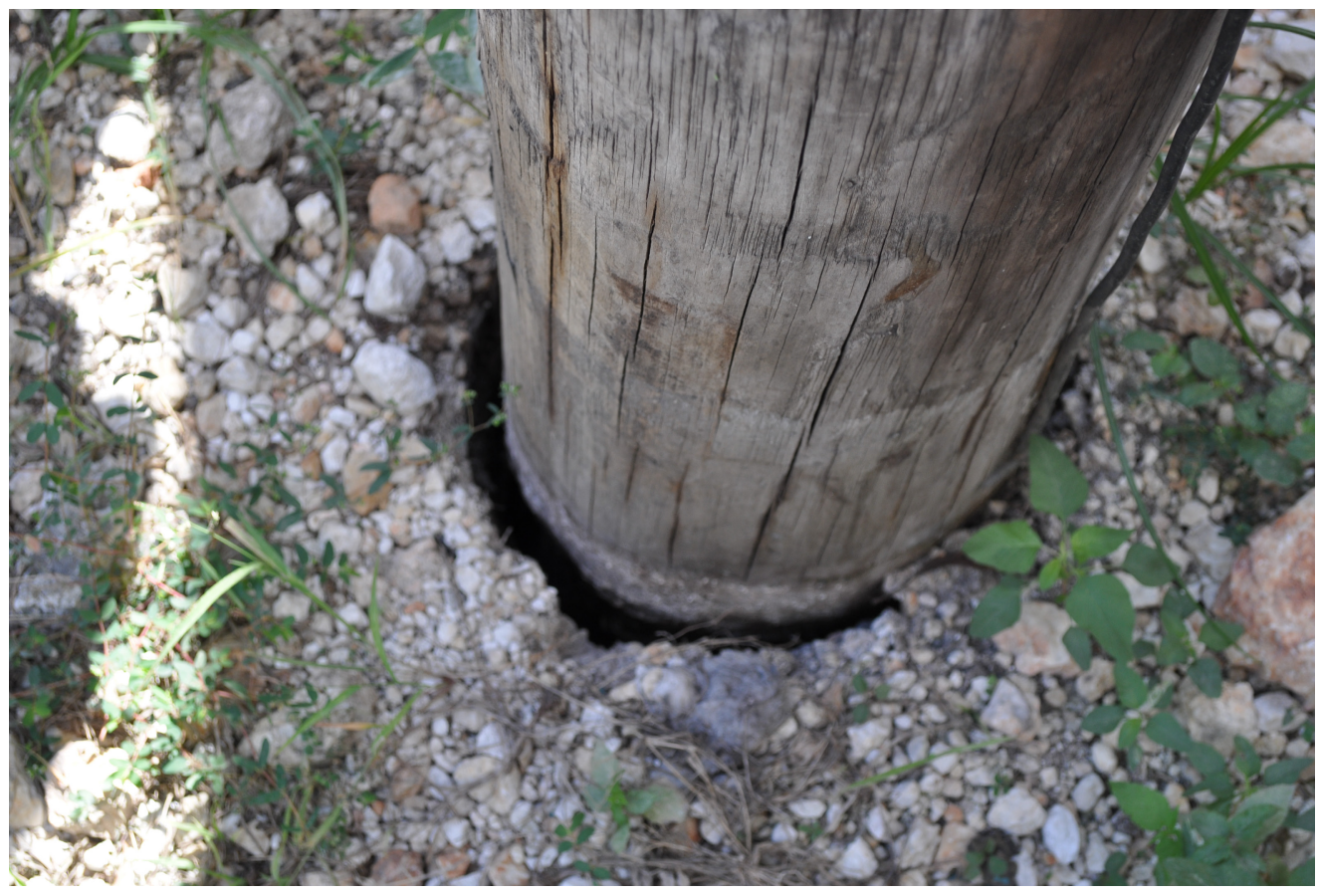

Figure 35. Base of power pole at hospital indicates some of the movement that occurred during the earthquake.

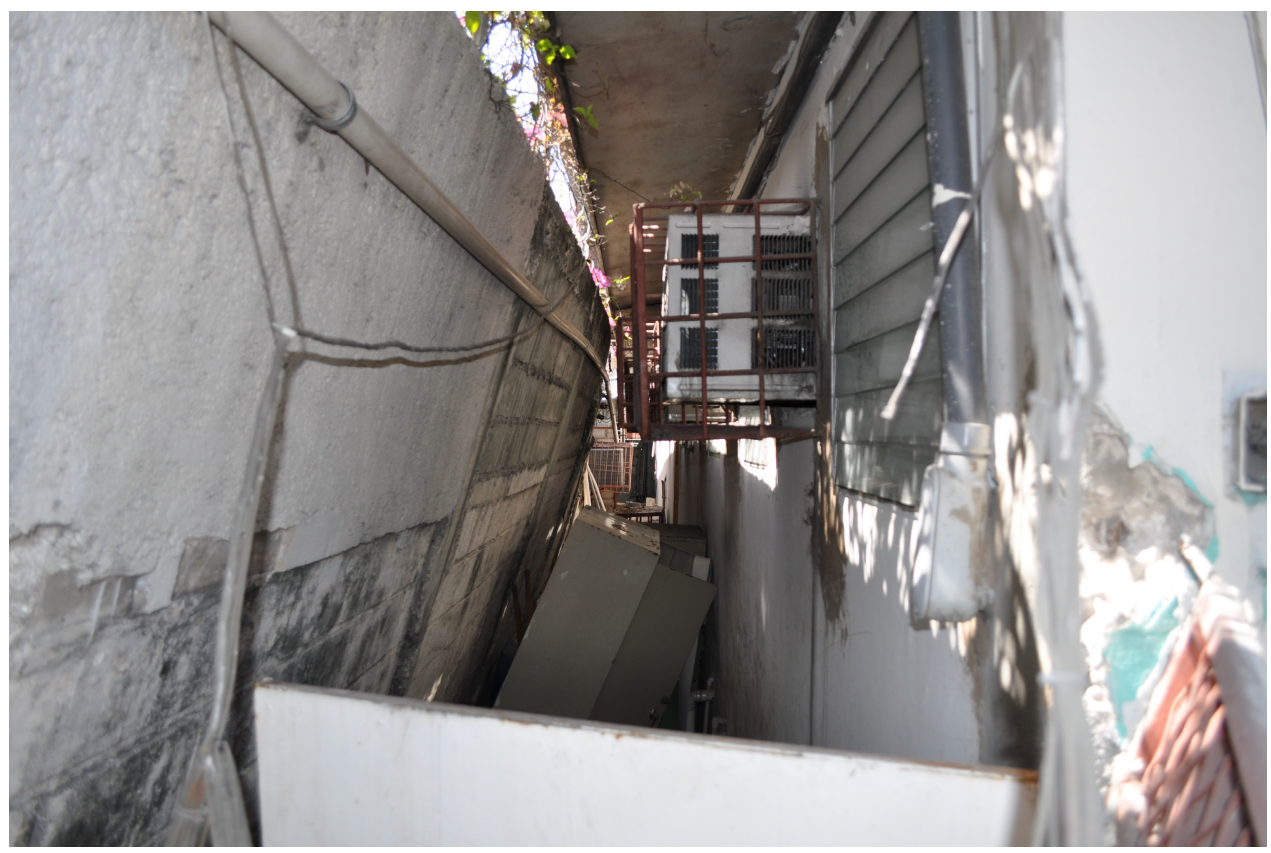

Figure 36. As with many masonry walls, the earthquake caused this one at the hopsital to lean. In this case, the wall is leaning towards occupied office space. 


\section{Quantification of Damage}

The observed damage was devastating in certain areas and light in others, even within Port-auPrince. Some of the variables affecting these differences include epicentral distance, soil conditions, quality of materials, quality of construction, and building type and connection details. To estimate the percentage of structures damaged in two regions, we walked specified routes and photographed every structure along both sides of the street. The two selected routes were within the downtown areas of Port-au-Prince and Léogâne.

A three-level rating was used to categorize damage in the two areas surveyed. Damage level 1 signified no or only minor damage to the structure. Structures that required repair but did not lose any primary structural element were assigned a damage level of 2. Damage level 3 indicated the loss of at least a column, bearing wall, or beam leading to the collapse of a portion, a story, or the total structure.

The Port-au-Prince downtown area was significantly damaged, and many structures collapsed. Many of the streets were blocked by the rubble of collapsed buildings. In Port-au-Prince we surveyed 107

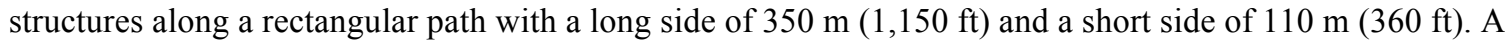
total of 42 buildings were assigned damage level 1, 35 were assigned damage level 2, and the remaining 30 represent the number of collapsed structures (level 3). In this section of Port-au-Prince, 28 percent of the structures collapsed, and 61 percent either collapsed or were damaged enough to require repairs. Figure 37 shows the damage map of the Port-au-Prince survey. The blue line shows the route. The southeast corner, adjacent to the National Palace, was where the survey commenced $\left(18.543576^{\circ} \mathrm{N}, 72.339897^{\circ} \mathrm{W}\right)$. The red pushpins represent structures of damage level 3. The National Palace was not included in our survey; it is shown only for reference.

Léogâne is the closest significant population center to the epicenter of the earthquake (approximately $11 \mathrm{~km}$ or $7 \mathrm{mi}$ ). In Léogâne we surveyed 52 structures along an L-shaped route with a long side of $380 \mathrm{~m}$ $(1,250 \mathrm{ft})$ and a short leg of $110 \mathrm{~m}(360 \mathrm{ft})$. In this area, only four structures met the criteria for damage level 1. Sixteen structures were classified as damage level 2, and the remaining 32 structures (62 percent) were collapsed to some degree. A damage map of the Léogâne route is shown in Fig. 38. The green pushpin markers represent the level 1 structures. The red pins represent the partially or totally collapsed structures (damage level 3). The walking route, shown with the blue line, began at the southeast road intersection $\left(18.508687^{\circ} \mathrm{N}, 72.629998^{\circ} \mathrm{W}\right)$.

The routes selected in both locations appeared to be similar to other sections of the respective towns but likely represent with high levels of damage. Some areas of Port-au-Prince, such as Pétion-Ville, experienced much less damage, possibly due to less intense ground motions and better construction quality. 


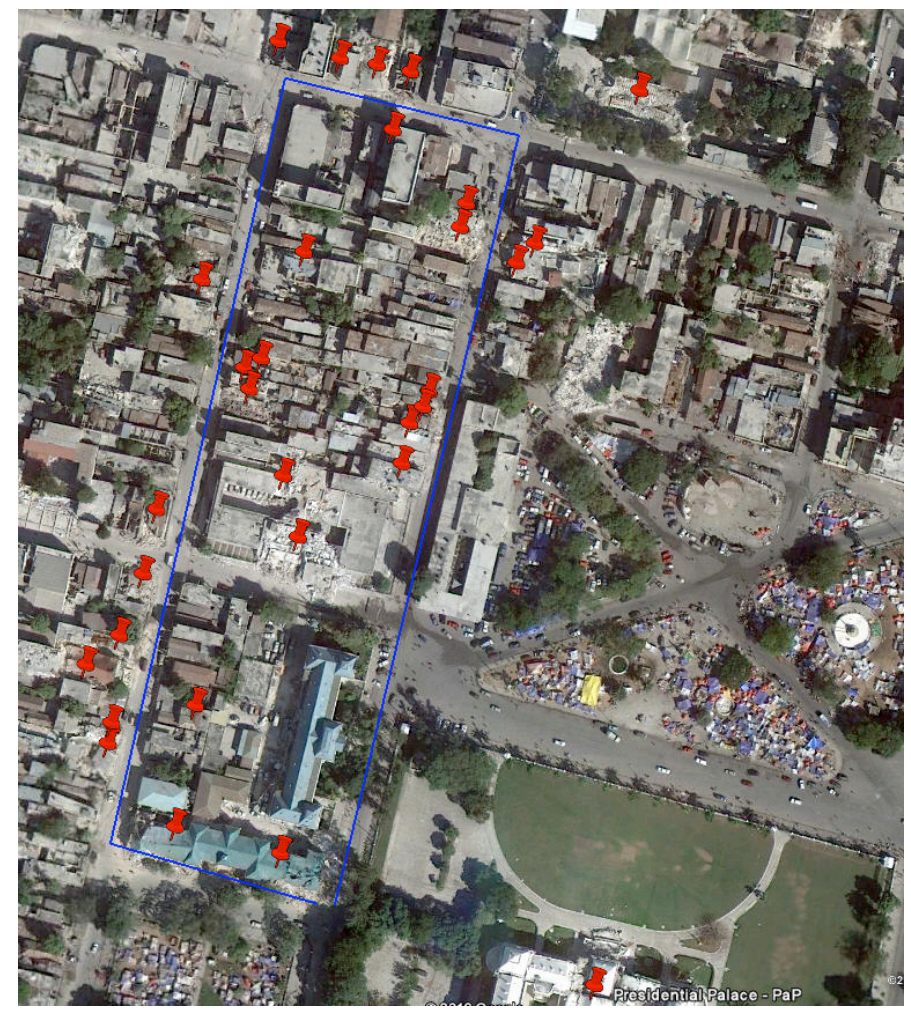

Figure 37. Damage map indicating collapsed structures (red) along the surveyed route in Port-au-Prince (Source of base photo: Google Earth).

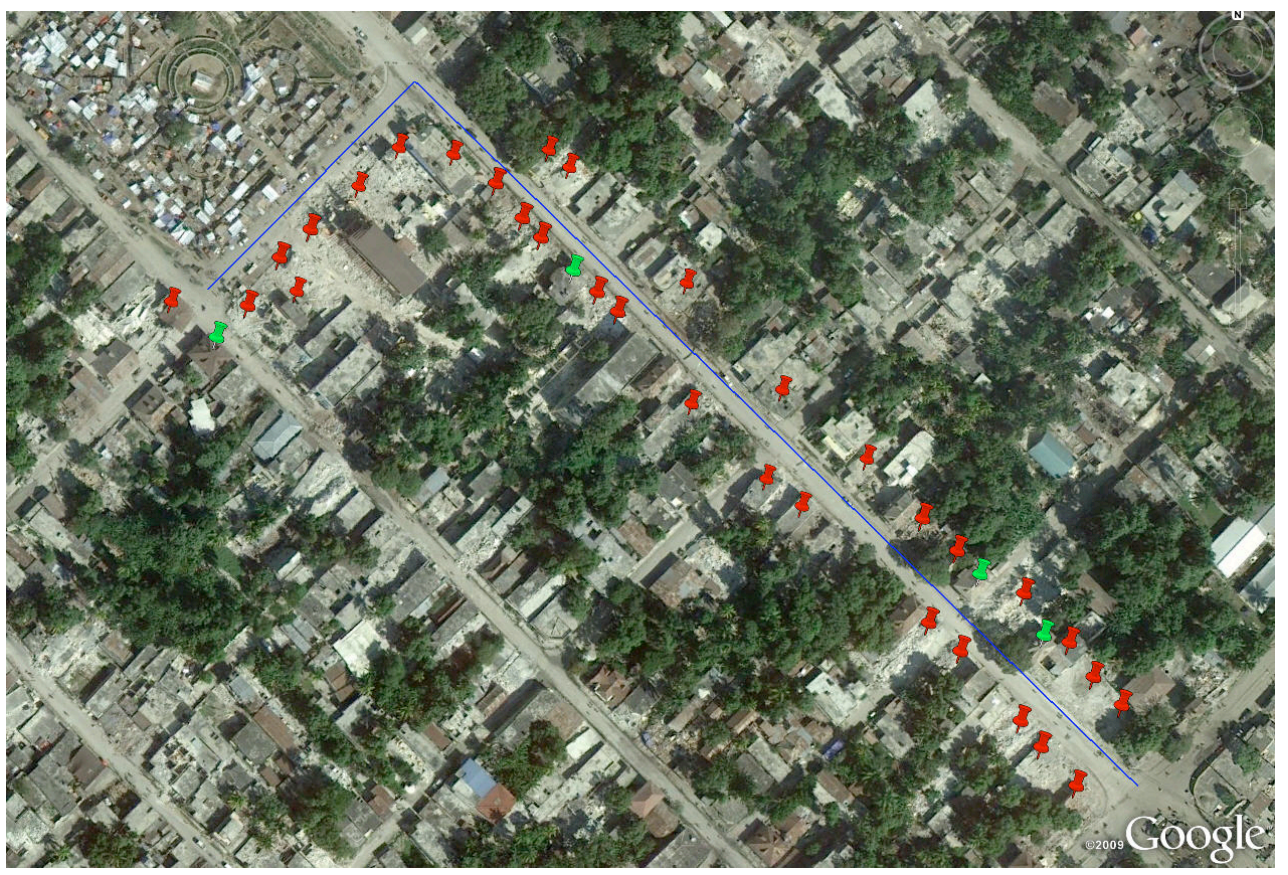

Figure 38. Damage map indicating collapsed (red) and undamaged (green) structures along the surveyed route in Léogâne (Source of base photo: Google Earth). 


\section{Bridges}

We did not see or learn of any bridge collapses attributable to the earthquake. Within Port-au-Prince, most of the crossings over streams were accommodated by box culverts 2-2.5 m (6-8 ft) deep, which did not appear to be damaged. These crossings may nonetheless be hazardous in the future, because the large amount of garbage that has accumulated upstream of these culverts may combine with silt and debris to prevent water from passing through the culverts. Once rains return to Port-au-Prince, the overflow of these culverts may pose a health hazard to displaced residents, some of who are living on or near these culverts (fig. 39).

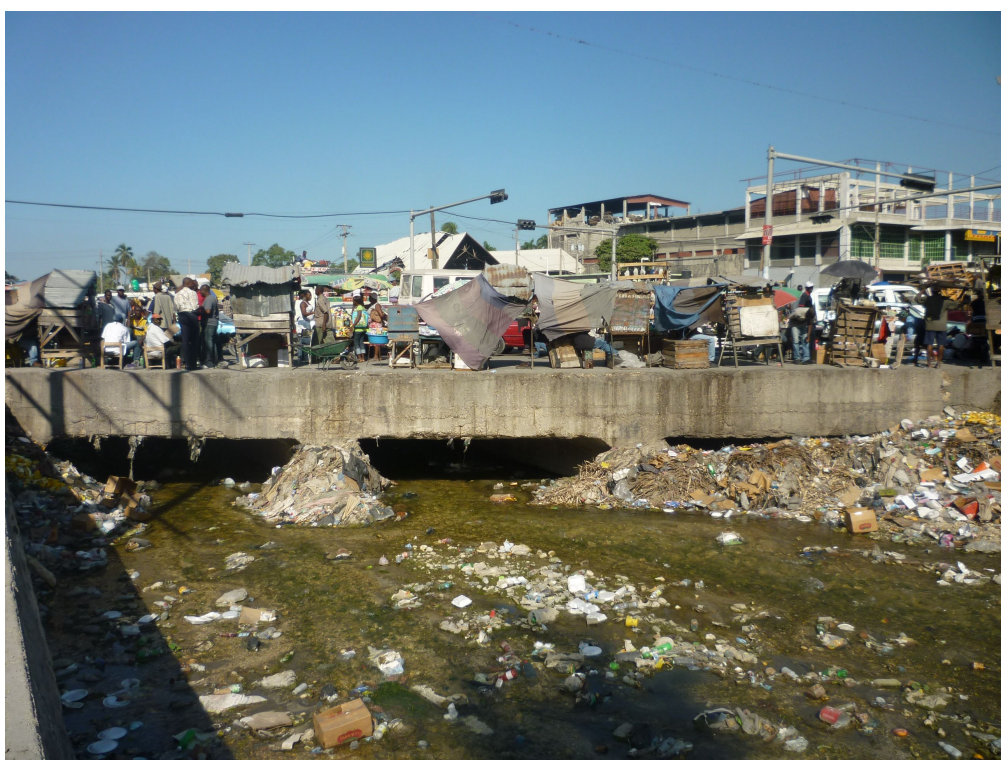

Figure 39. View of box culvert in Port-au-Prince, looking downstream.

Along the Route Nationale No. 2, small streams were also spanned by culverts. The culverts themselves were not damaged, but in at least one case the approaches to the culvert settled relative to the culvert itself, resulting in a step of approximately $150 \mathrm{~mm}$ (6 in.) (fig. 40).

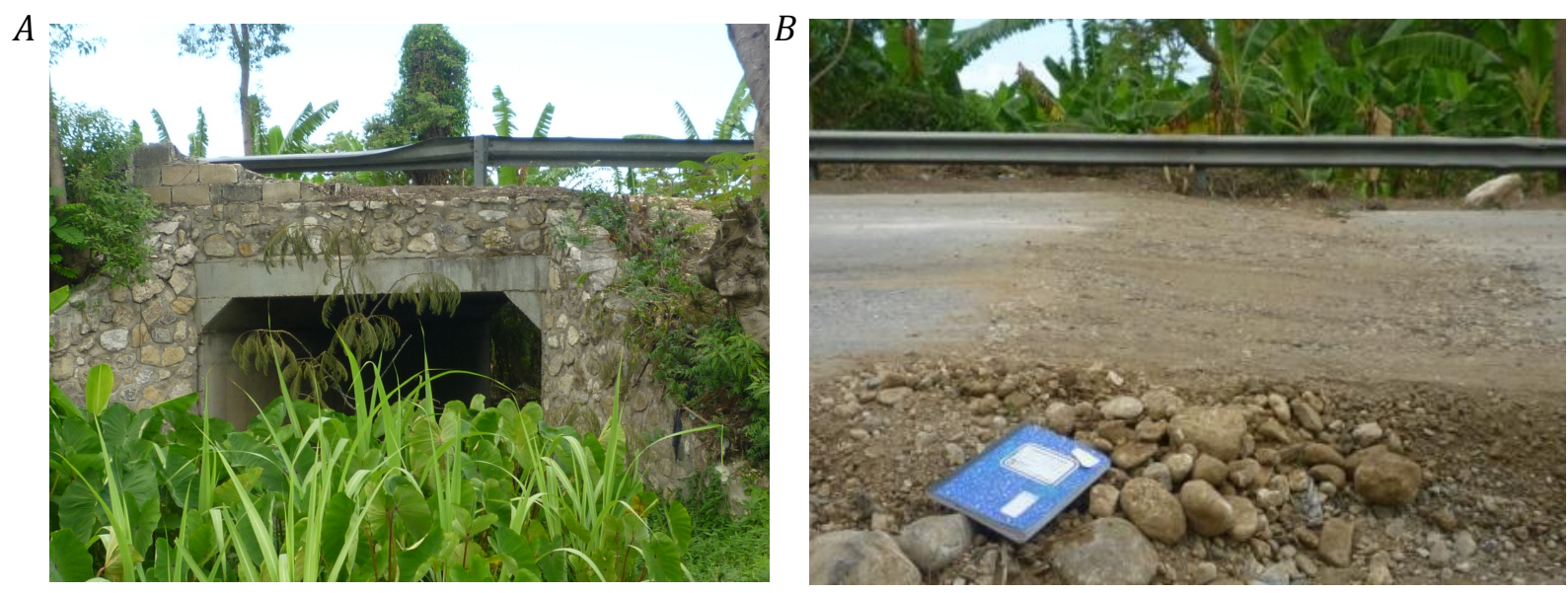

Figure 40. Settlement of approach to culvert. $A$, Elevation. $B$, Close-up of step.

The main river crossings on Nationale No. 2 were spanned by bridges with precast girders resting on cast-in-place reinforced concrete bents and supporting a cast-in-place deck. We observed damage on two 
such bridges. The bridge over the Momance River $\left(18.524999^{\circ} \mathrm{N}, 72.584302^{\circ} \mathrm{W}\right)$ had minor pounding damage at the shear key at one of the intermediate supports that did not appear to have been adequately and/or properly reinforced.

In the Carrefour section of Port-au-Prince $\left(18.549984^{\circ} \mathrm{N}, 72.416429^{\circ} \mathrm{W}\right)$, the external shear keys (fig. $41 \mathrm{~A}$ ) of a similar bridge were damaged at both intermediate supports. This failure was apparently caused by the lack of hook anchorage at the end of the top beam reinforcement. As shown in figure $41 B$, one of these bars pulled out approximately $50 \mathrm{~mm}(2 \mathrm{in}$.) from the surrounding concrete.
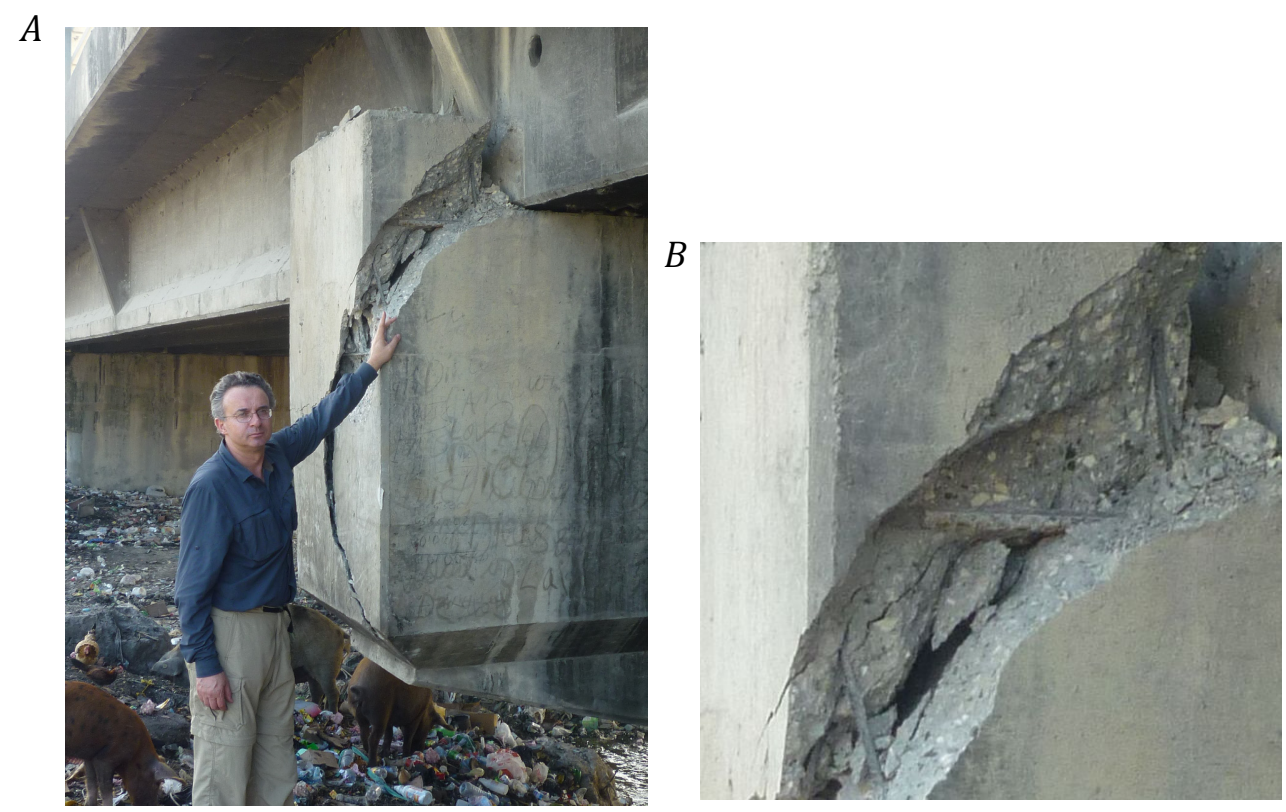

Figure 41. Damage to shear key at intermediate support of bridge. $A$, Overview. $B$, Pull-out of beam reinforcement.

\section{Port Facilities}

\section{Port de Port-au-Prince}

The main port in Port-au-Prince $\left(18.5553^{\circ} \mathrm{N}, 72.3497^{\circ} \mathrm{W}\right)$ suffered extensive damage during the earthquake, inhibiting the delivery of relief supplies to areas affected by the earthquake. The port is operated by the Autorite Portuaire Nationale (APN) and consists of two separate facilities designated as the North Wharf and South Pier. According to data provided by APN, the port handled 978,575 metric tons of cargo in 2005-2006 from 490 ship calls. An annotated aerial image of the port is shown in figure 42. 


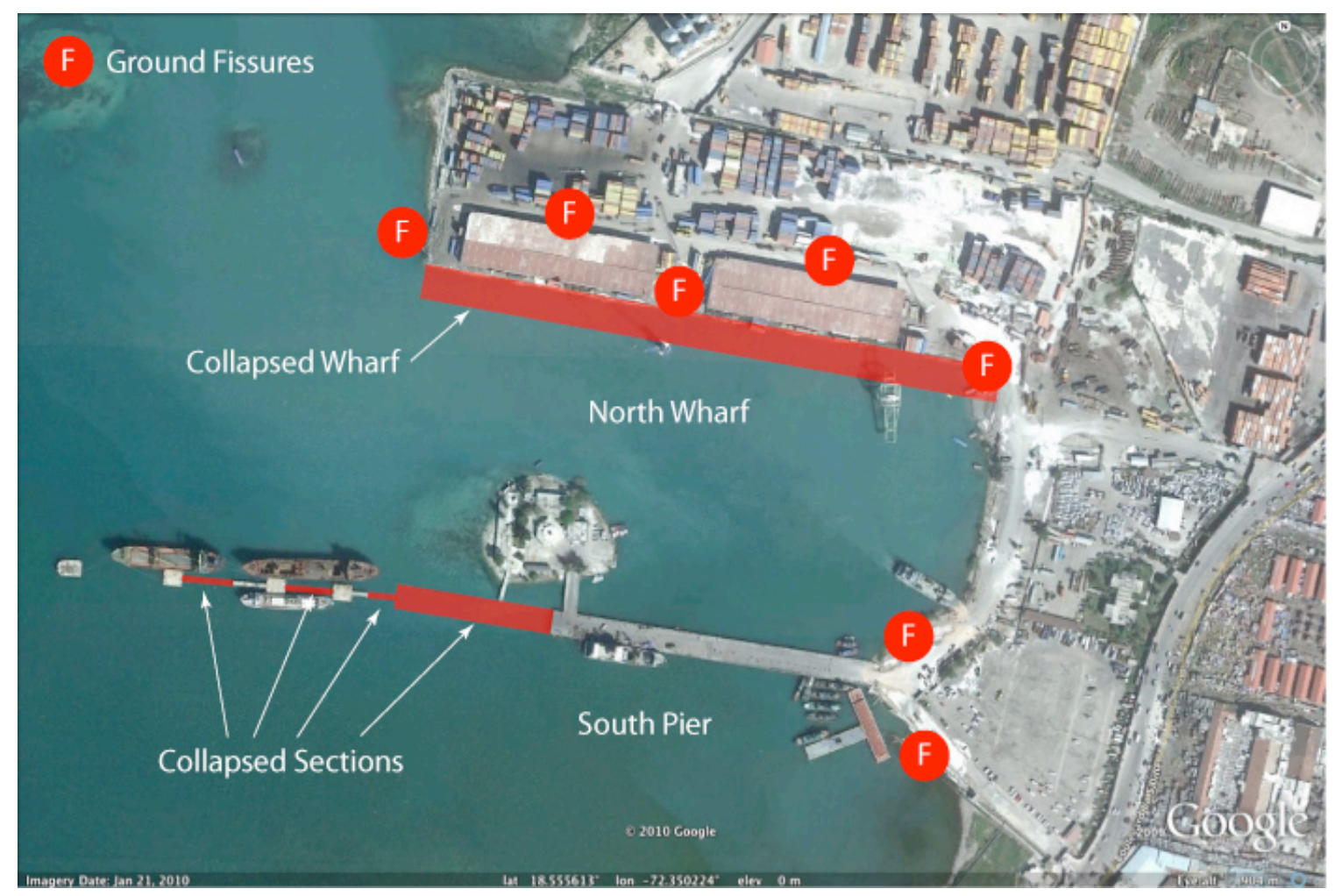

Figure 42. Annotated aerial image of Port de Port-au-Prince (Google Earth).

The North Wharf collapsed, most likely due to liquefaction-induced lateral spreading. Numerous surface manifestations of the liquefaction are present in the vicinity of the North Wharf. Light-colored areas in figure 42 are sand boils and can be seen in the eastern half of the container storage yard and behind and between the two warehouses. The locations where large lateral spreading fissures were observed are shown in figure 42 with symbols. Figure 43 shows two examples of these fissures at the eastern and western ends of the wharf area. 


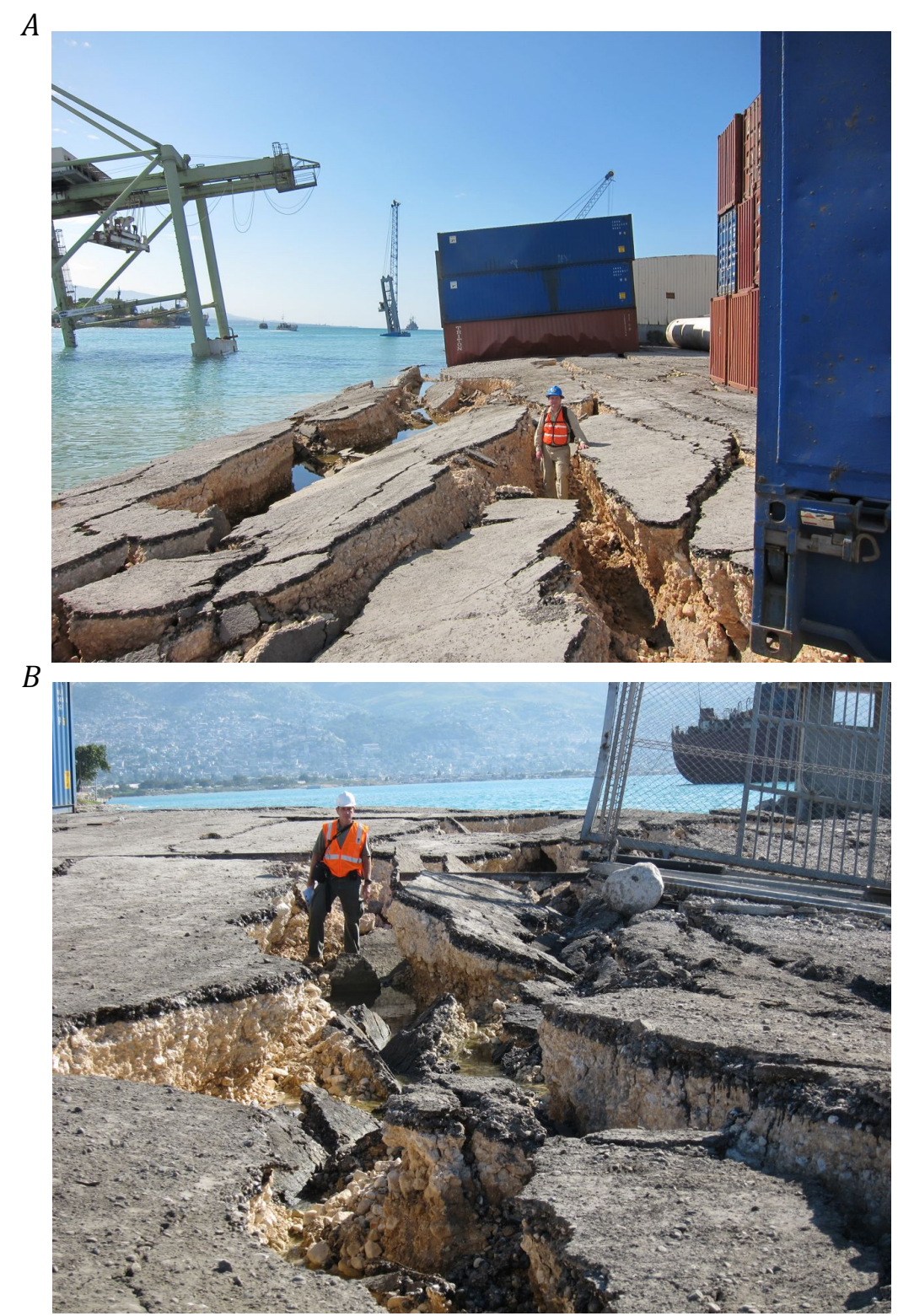

Figure 43. Fissures caused by lateral spreading at $(A)$ eastern and $(B)$ western ends of the North Wharf.

The North Wharf consists of a pile-supported marginal wharf approximately $450 \mathrm{~m}(1,500 \mathrm{ft})$ in length and $20 \mathrm{~m}(65 \mathrm{ft})$ in width, likely constructed on un-engineered fill of unknown origin. The water depth is 8 to $10 \mathrm{~m}$ ( 25 to $30 \mathrm{ft}$ ). Other information about the construction of the wharf, such as date of construction and the number and size of piles, is unknown at present. Immediately adjacent to the wharf are two steel-frame warehouses, each approximately $150 \mathrm{~m}$ by $40 \mathrm{~m}$ ( $500 \mathrm{ft}$ by $130 \mathrm{ft})$. Behind the warehouses is a container storage yard with a large number of mostly empty containers stacked two to four high at the time of the earthquake. There are three cranes at the North Wharf, including one 15-m (50-ft) gauge, Aframe container crane, and two rubber-tired mobile cranes.

Apparently, two of the three cranes were on the North Wharf at the time of the earthquake and are now partially submerged. Figure 44 shows the A-frame container crane in the foreground and a submerged mobile crane in the background. The container crane had no obvious structural damage. The second mobile crane was parked between the two warehouses and also appeared to be undamaged. 


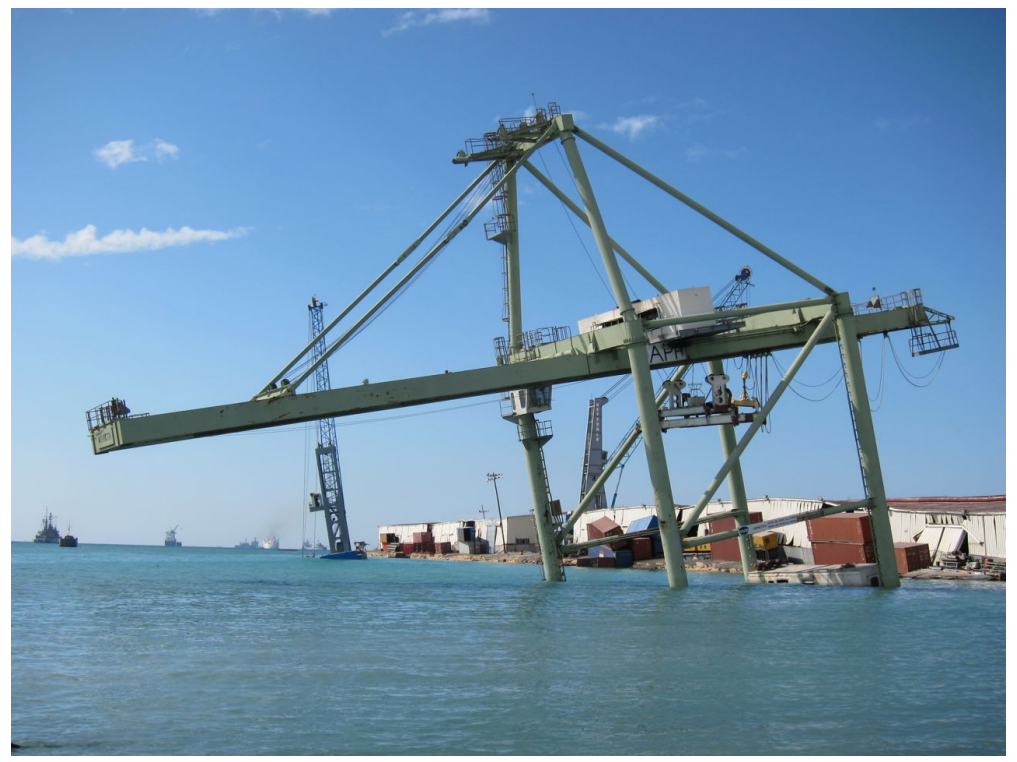

Figure 44. Submerged $15 \mathrm{~m}$ gauge container crane (foreground) and mobile crane (background).

Interestingly, a photo taken by an unknown photographer (apparently aboard a ship docked at the eastern end of the wharf) immediately after the earthquake (fig. 45) shows that the landside legs of the crane are still above water. However, a photo taken by the U.S. Coast Guard during an overflight of the port at midday on January 13, 2010, shows that the crane is in the same position as in Fig. 44 (that is, landside legs submerged). The National Earthquake Information Center reports no fewer than 45 aftershocks ranging from $M_{w} 4.0$ to 6.0 following the main shock until 1:54 pm EST on January 13, 2010. These photos raise the likelihood that a portion of the observed permanent displacements caused by liquefaction occurred as a result of aftershocks.

The South Pier is a pilesupported structure that was originally $380 \mathrm{~m}(1,250 \mathrm{ft})$ in length and $18 \mathrm{~m}(60 \mathrm{ft})$ in width. A large bridge and a small pedestrian bridge that are approximately perpendicular to the longitudinal axis of the pier connected the pier to an island where the port security office is located. The western end of the pier was also connected to three dolphins by small pedestrian bridges. All of the bridges were also pile-supported structures. It is believed that an American or British contractor constructed the pier in about 1975 . The piles supporting the pier are approximately 510-mm square (1.7

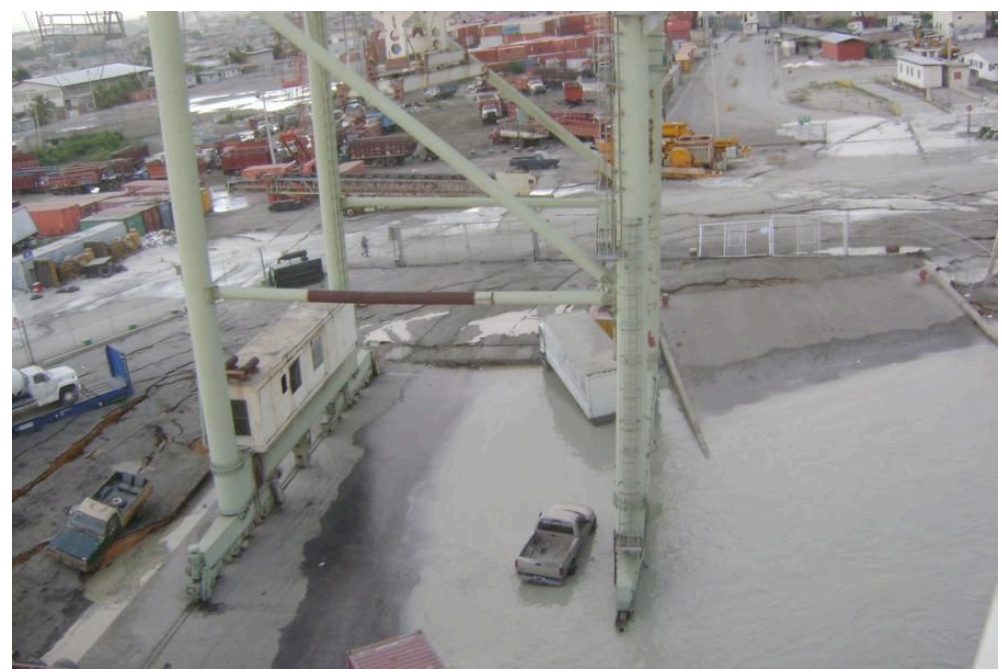

Figure 45. Photo taken immediately after the earthquake showing the landside legs of the crane above water. (Source: James Bobbitt, BP Shipping USA).

$\mathrm{ft}$ ) concrete piles on 4.3 - to $4.9-\mathrm{m}$

(14- to 16-ft) centers and include both vertical and battered piles. The pile bents are $1.5 \mathrm{~m}(5 \mathrm{ft})$ deep and

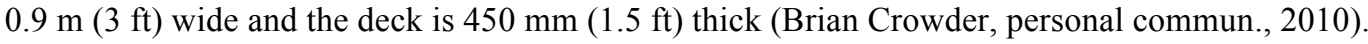


During the earthquake, the westernmost $120 \mathrm{~m}(400 \mathrm{ft})$ of the South Pier and portions of the pedestrian bridges linking the dolphins collapsed and are now submerged. One hypothesis is that the large bridge connecting the pier to the island and the abutment of the pier provided sufficient lateral restraint to prevent the eastern portion of the pier from also collapsing. Nonetheless, the eastern portion was heavily damaged. U.S. Army divers inspected the piles following the earthquake to determine whether the pier could support loads imposed by trucks carrying relief supplies. They found that approximately 40 percent of the piles were broken, 45 percent were moderately damaged, and 15 percent were slightly damaged. In general, the batter piles were more heavily damaged than the vertical piles. An aftershock on January 26, 2010, may have caused more damage, and the pier remained closed to traffic as of February 1, 2010.

Engineers from U.S. Naval

Facilities Engineering Command have developed a strategy that they hope will allow them to repair the damage in about 10 weeks from the start of construction.

In addition to the damage to the piles supporting the South Pier, the abutment also experienced liquefaction-induced lateral and vertical displacements.

Approximately

$1 \mathrm{~m}(3.3 \mathrm{ft})$ of fill was required to re-level the approach to the pier, as shown in figure 46.

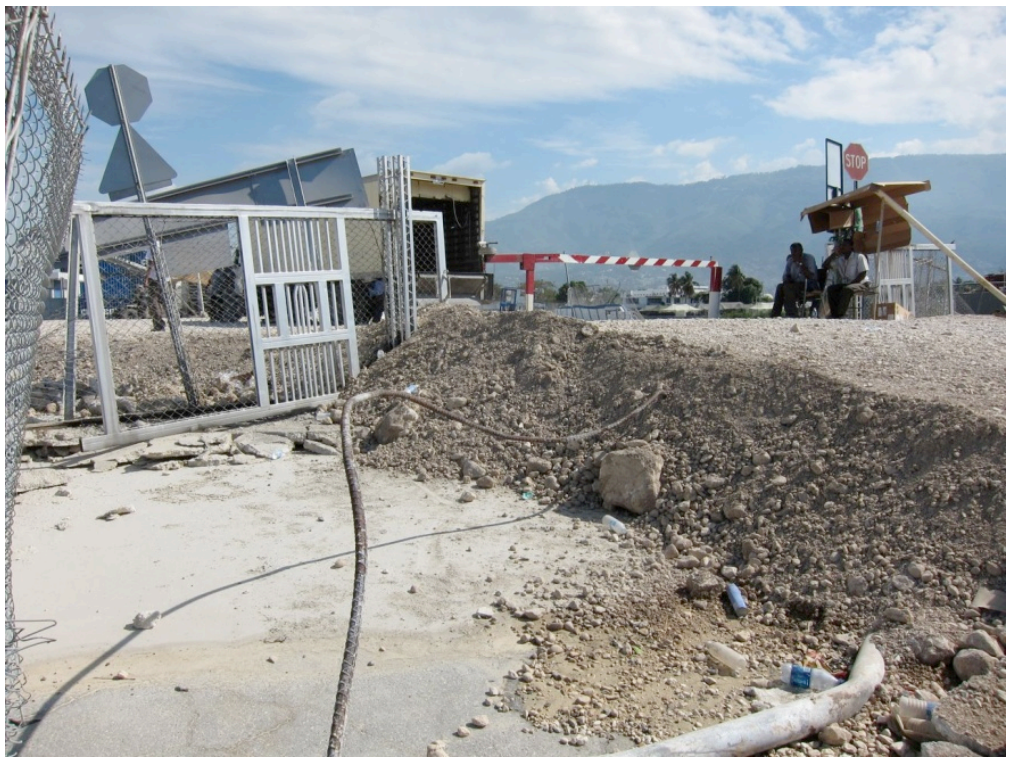

Figure 46. Approximately $1 \mathrm{~m}(3.3 \mathrm{ft})$ of fill was required to level the approach to the South Pier of the port. 

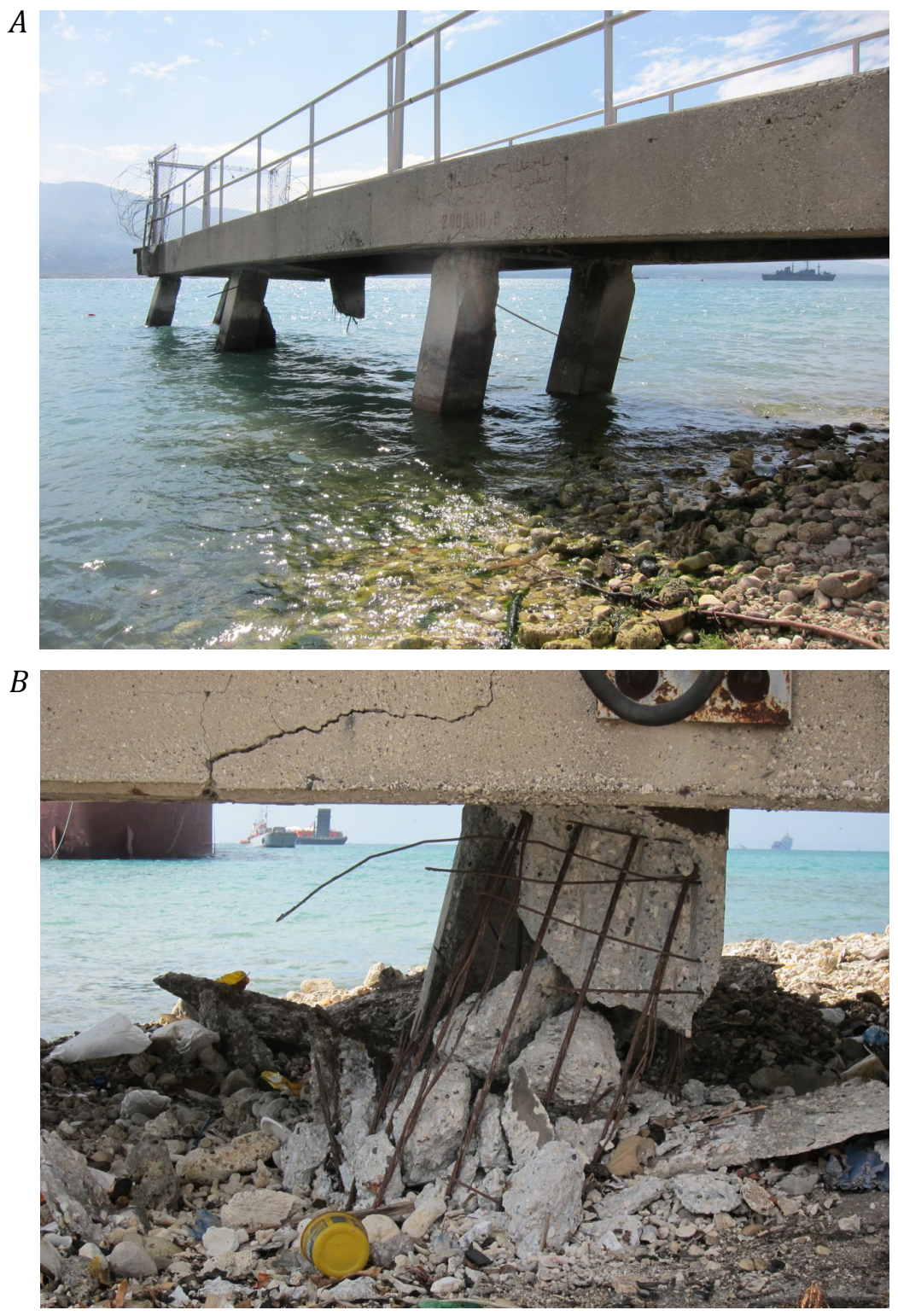

Figure 47. Damage at the port. $A$, Damage to piles supporting the pedestrian bridge connecting the South Pier to the island. $B$, Extensive damage to the landward row of piles.

The piles supporting the small pedestrian bridge connecting the South Pier to the island could be readily observed. Figure 47 shows the damage to these piles, including the extensive damage to the landward row of piles. 
Finally, one of the main entrance roads to the port was damaged heavily by liquefaction-induced lateral spreading, as shown in figure 48.

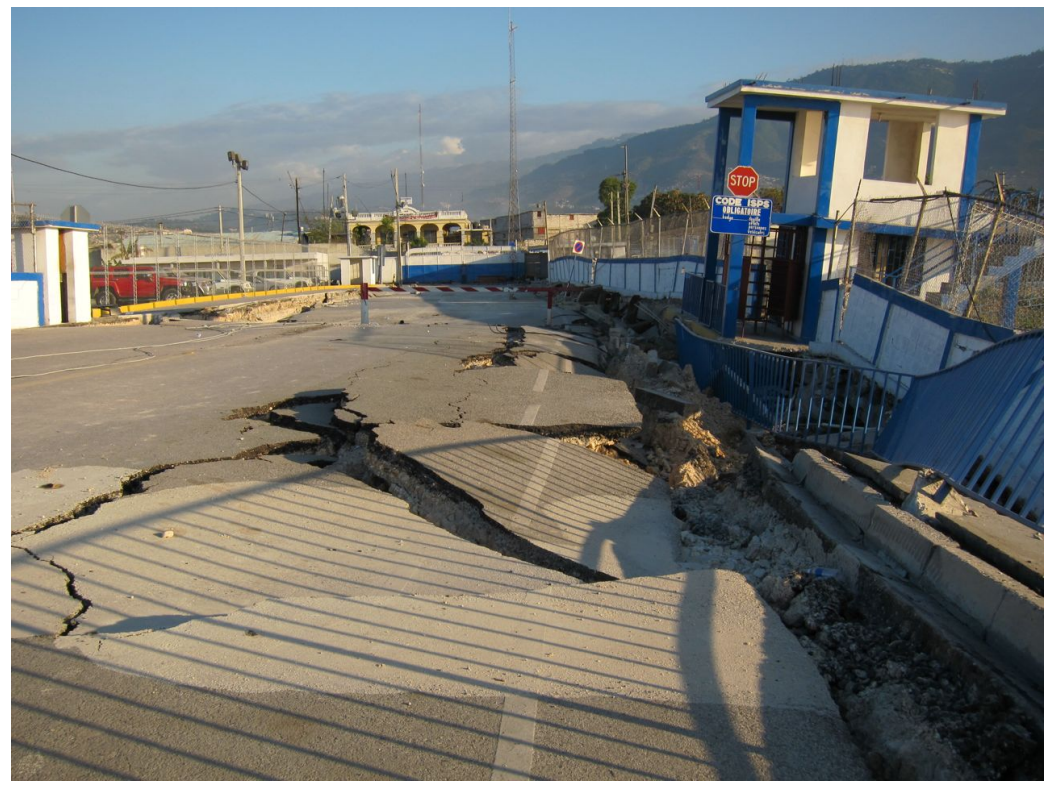

Figure 48. Damage to entrance road caused by lateral spreading.

\section{Thor Marine Oil Terminal}

At the Thor marine oil terminal $\left(18.540528^{\circ} \mathrm{N}, 72.385710^{\circ} \mathrm{W}\right)$ one portion (approximately $230 \mathrm{~m}$ or 1,500 $\mathrm{ft}$ long) of the pipelines used to offload petroleum products is supported on an embankment constructed out into the water, and a second portion (approximately $120 \mathrm{~m}$ or $400 \mathrm{ft}$ long) is supported on piles. The pile-supported portion was undamaged, but the embankment-supported portion experienced some damage due to vertical displacement of the embankment, as shown in figure 49 (Scott Chodkiewicz, personal commun., 2010). The damage was not serious enough to prevent use of the pipelines following the earthquake.

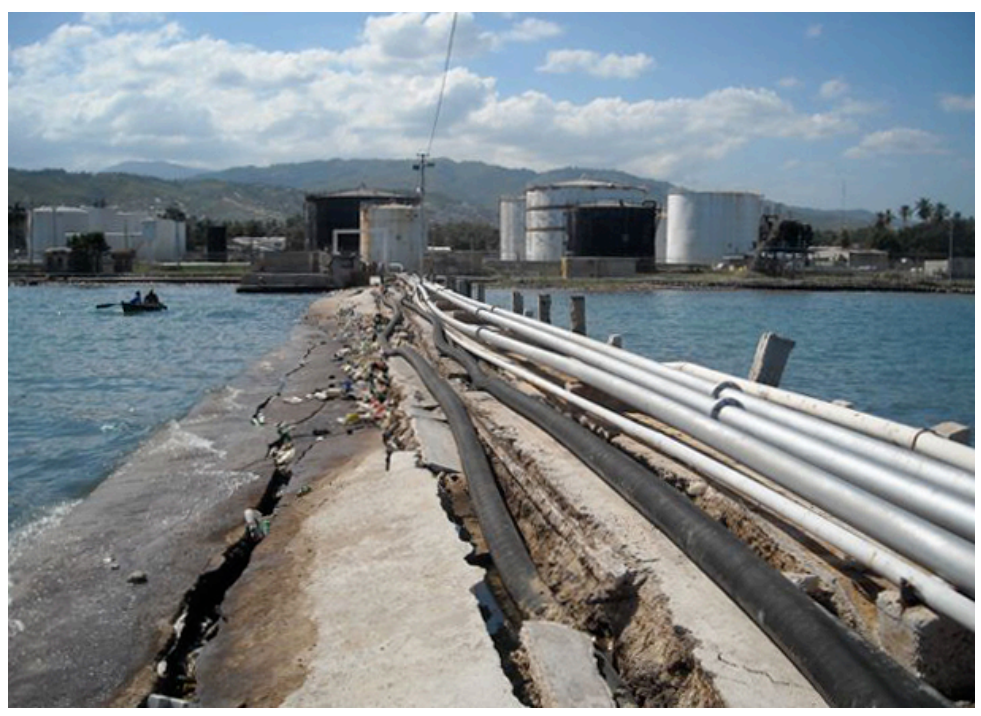

Figure 49. Embankment-supported petroleum pipelines at the Thor marine oil terminal. (Source: Scott Chodkiewicz, U.S. Army Corps of Engineers) 


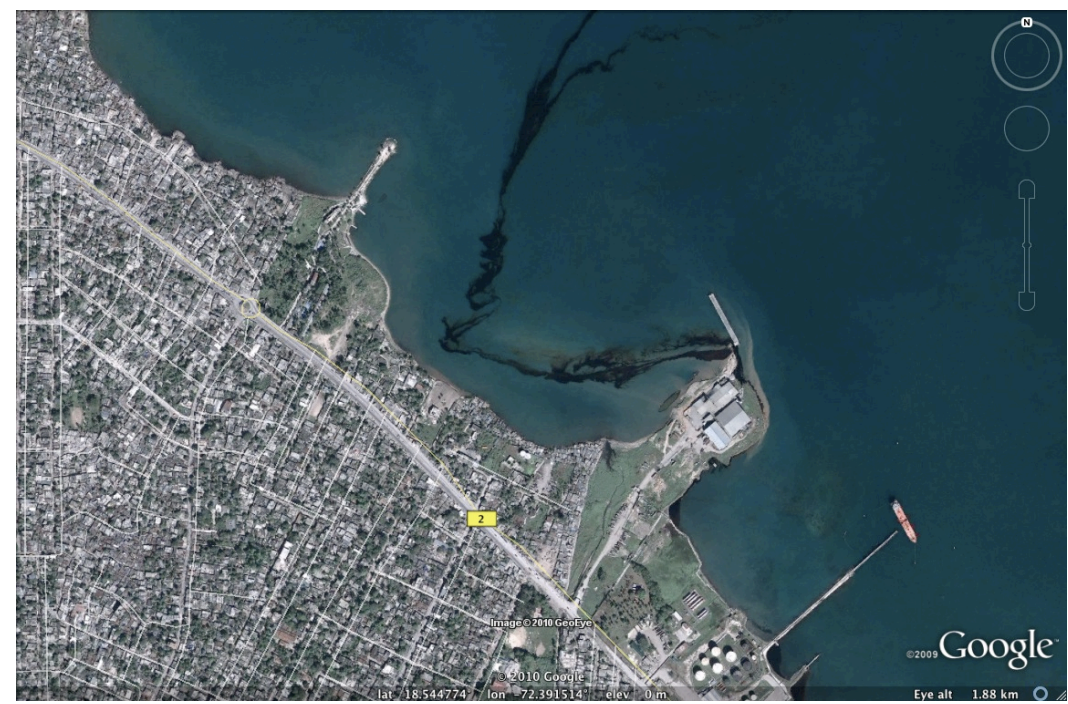

Figure 50. Satellite image of the Thor marine oil terminal on January 13,2010 , showing a small oil spill (Google Earth).

Damage to another facility at the Thor marine oil terminal resulted in a small oil spill (fig. 50) that was apparently contained quickly, because it is not seen in images from January 14, 2010, onward.

\section{Varreux Terminal}

At the Varreux terminal $\left(18.573944^{\circ} \mathrm{N}, 72.346119^{\circ} \mathrm{W}\right)$ a pile-supported pier collapsed during the earthquake, killing approximately 30 employees who were working on the pier (Scott Chodkiewicz, personal commun., 2010). A photo of the remaining portion of the pier is shown in figure 51.

\section{Port du Cap Haïtien}

We accompanied the U.S. Army to Cap Haitien on the northern coast of Haiti to assess the capabilities of the Port du Cap Haitien, the second largest port in Haiti, to handle relief and reconstruction supplies while the Port de Port-au-Prince is undergoing repairs. The pile-supported wharf facilities there were undamaged by the earthquake.

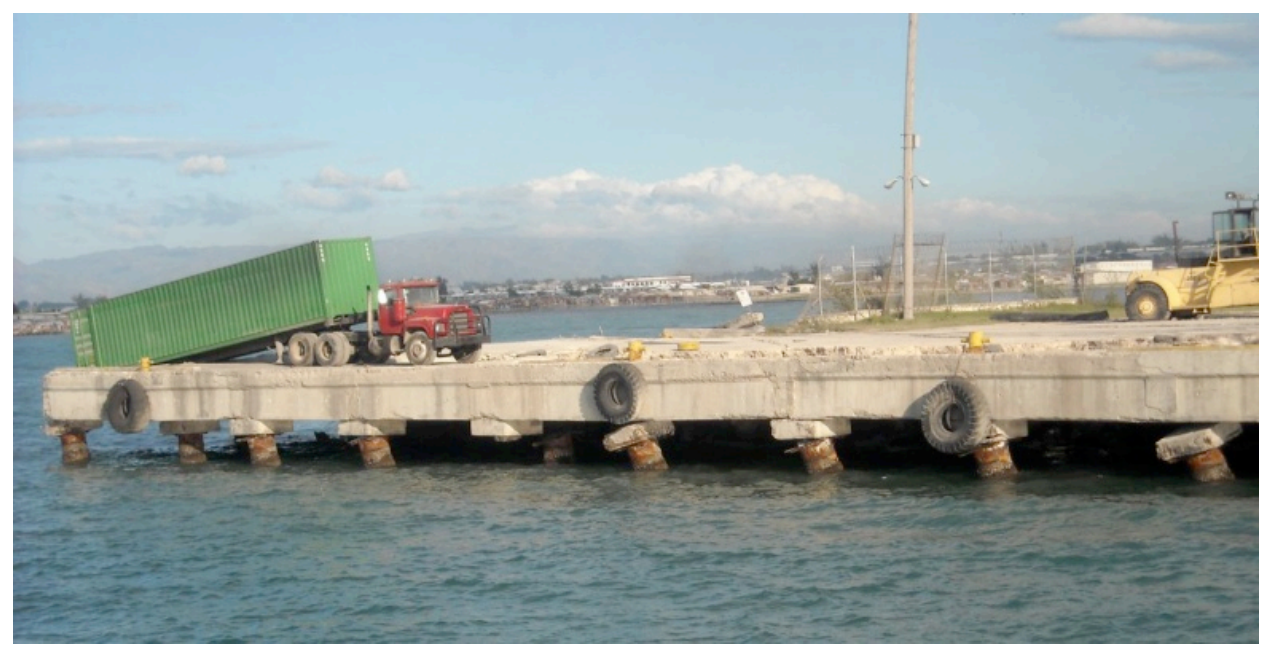

Figure 51. Remaining portion of pile-supported pier at the Varreux terminal (Source: Scott Chodkiewicz, U.S. Army Corps of Engineers). 


\section{Damage To Institutions}

The functioning of government infrastructure following a significant earthquake is critical to the success of the recovery and rebuilding effort. The January 12, 2010, earthquake disrupted the functioning of nearly all government institutions, as well as many of the United Nations and non-governmental organizations. These institutions lost key personnel and critical databases and records, as well as the use of facilities.

In addition to disrupting the operations of numerous clinics, hospitals, police stations, schools, and universities, the earthquake caused serious damage or the collapse of the:

- National Palace

- Legislative Palace

- Palace of Justice

- Ministry of Health

- Ministry of Interior

- Ministry of Finance and Economics

- MINUSTAH Headquarters

The National Palace, the Ministry of the Interior, and the Judicial and Legislative Palaces are shown in figure 52.

Churches, an important part of Haiti's societal infrastructure, were also damaged extensively. The Grand Cathedral in Port-au-Prince, a mainly reinforced concrete structure, collapsed, killing the Archbishop of Port-au-Prince and many worshippers. Two other churches with unreinforced masonry bearing walls in the downtown area were severely damaged, resulting in partial collapse. Figure 53 shows the collapse of the Grand Cathedral and the partial collapse of the Church of the Sacred Heart (Eglise Sacrè Coeur), an unreinforced masonry bearing-wall structure. Numerous smaller churches in other locations (for example, Grand Goâve, Léogâne) were damaged also, leading parishioners to hold services under tents, either on top of cleared sites of collapsed churches or adjacent to the collapsed structures. 

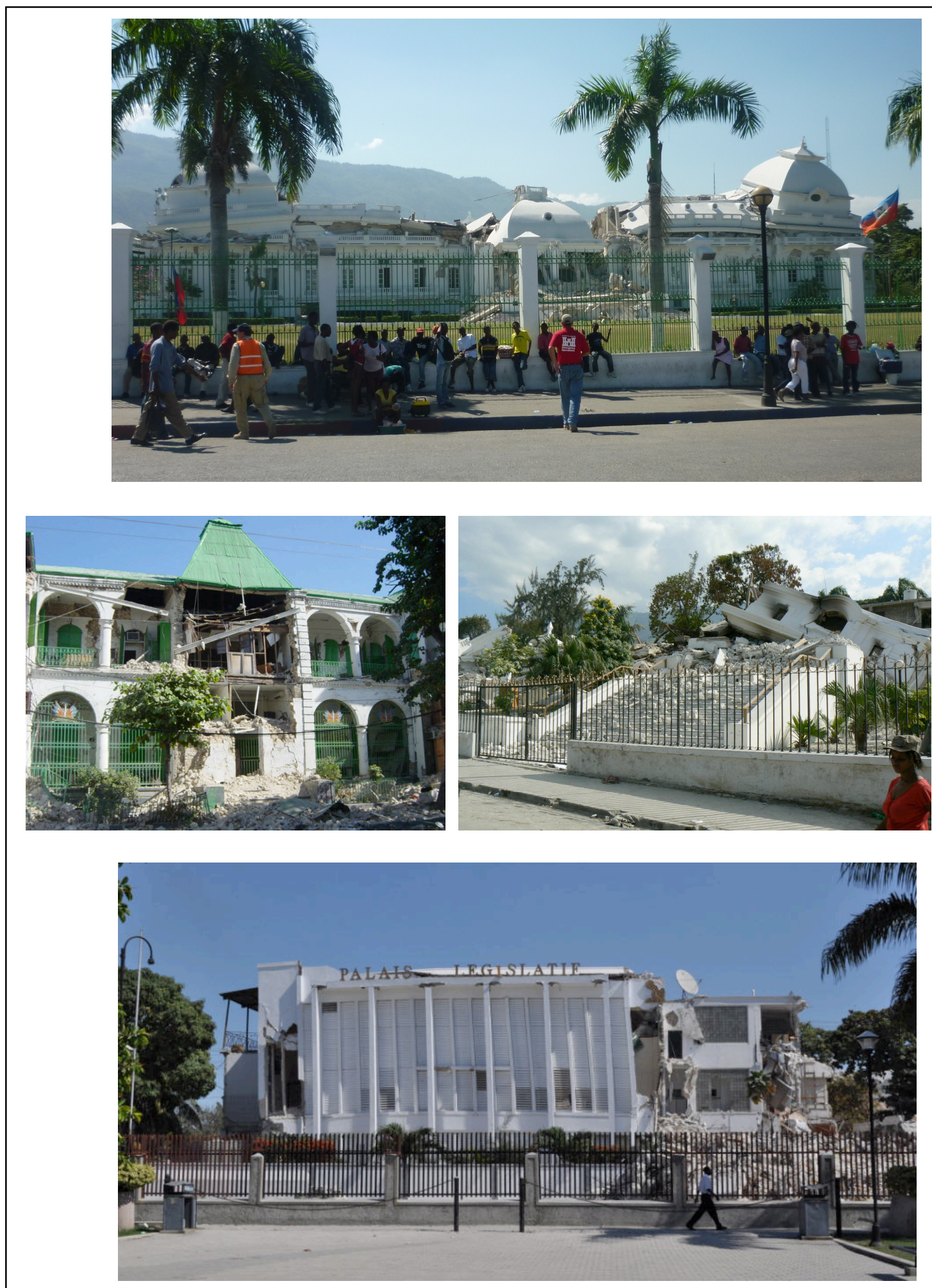

Figure 52. National Palace, Ministry of the Interior, and the Judicial and Legislative Palaces. 


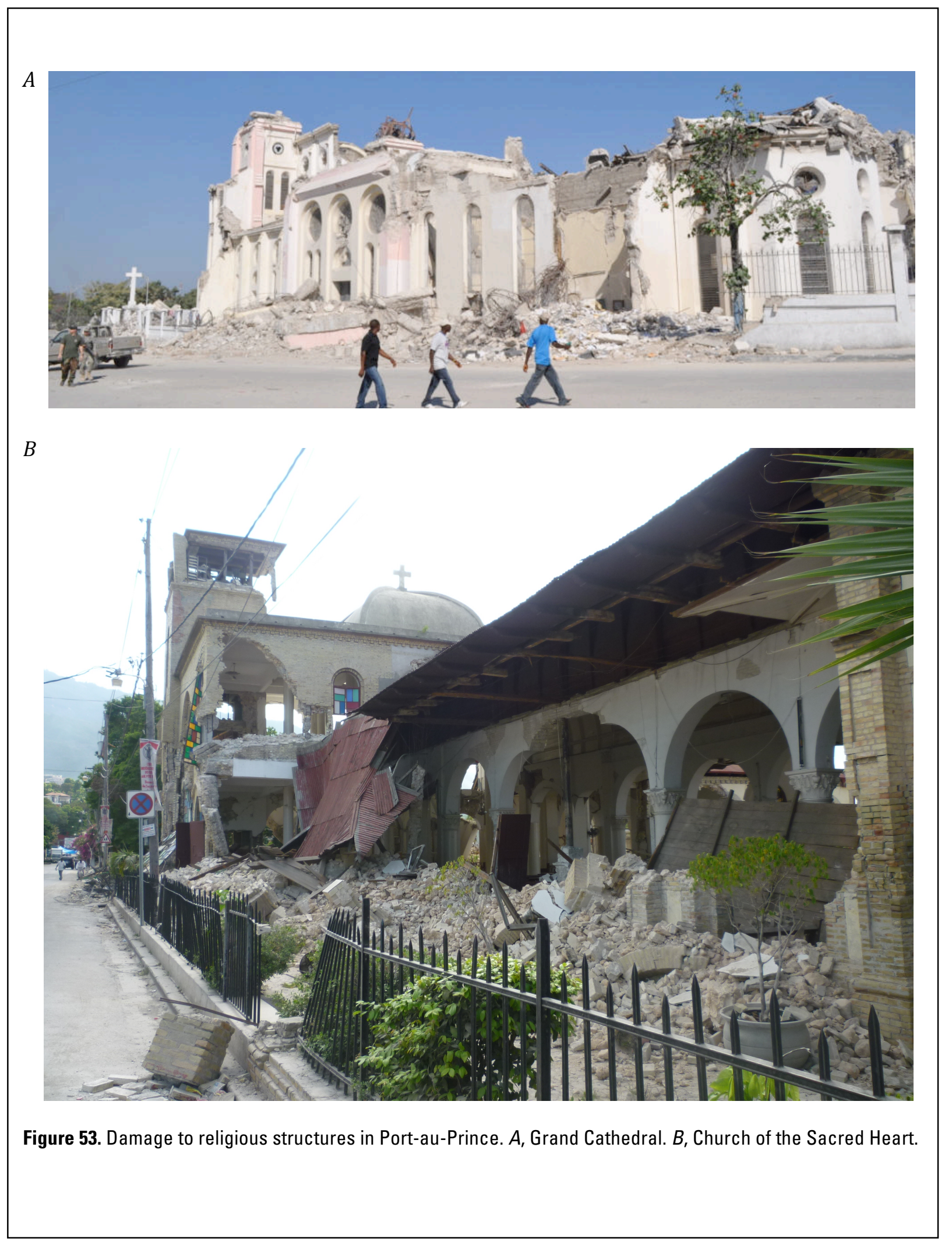




\section{Satellite Imagery}

A unique aspect of the response to this earthquake has been the extensive use of remote sensing data, including satellite imagery and aerial photography, to guide damage assessment, rescue and recovery efforts. The organizations involved in these efforts include ImageCat, the World Bank's Global Facility for Disaster Reduction and Recovery, the Rochester Institute of Technology, the Earthquake Engineering Research Institute, and MCEER. ImageCat, in collaboration with other partners, formed the Global Earth Observation Catastrophe Assessment Network (GEO-CAN). This network is using very high resolution aerial and satellite imagery to determine which structures have completely or partially collapsed or are heavily damaged. Their findings have been and will be used by the World Bank to help develop plans for the reconstruction effort. The damage assessment is being done by volunteer scientists and engineers in government, academia, and private practice who are comparing previous imagery with the high-resolution imagery captured after the earthquake. More than 500 skilled engineering personnel in remote locations have participated in damage assessment to date. They have also used light detection and ranging (LIDAR) technology to create a three-dimensional map of the region to further enhance their knowledge of the damage. An example of the damage map from ImageCat and GEO-CAN is shown in figure 54. The red lines in the figure indicate structures that have sustained damage discernable from the imagery.

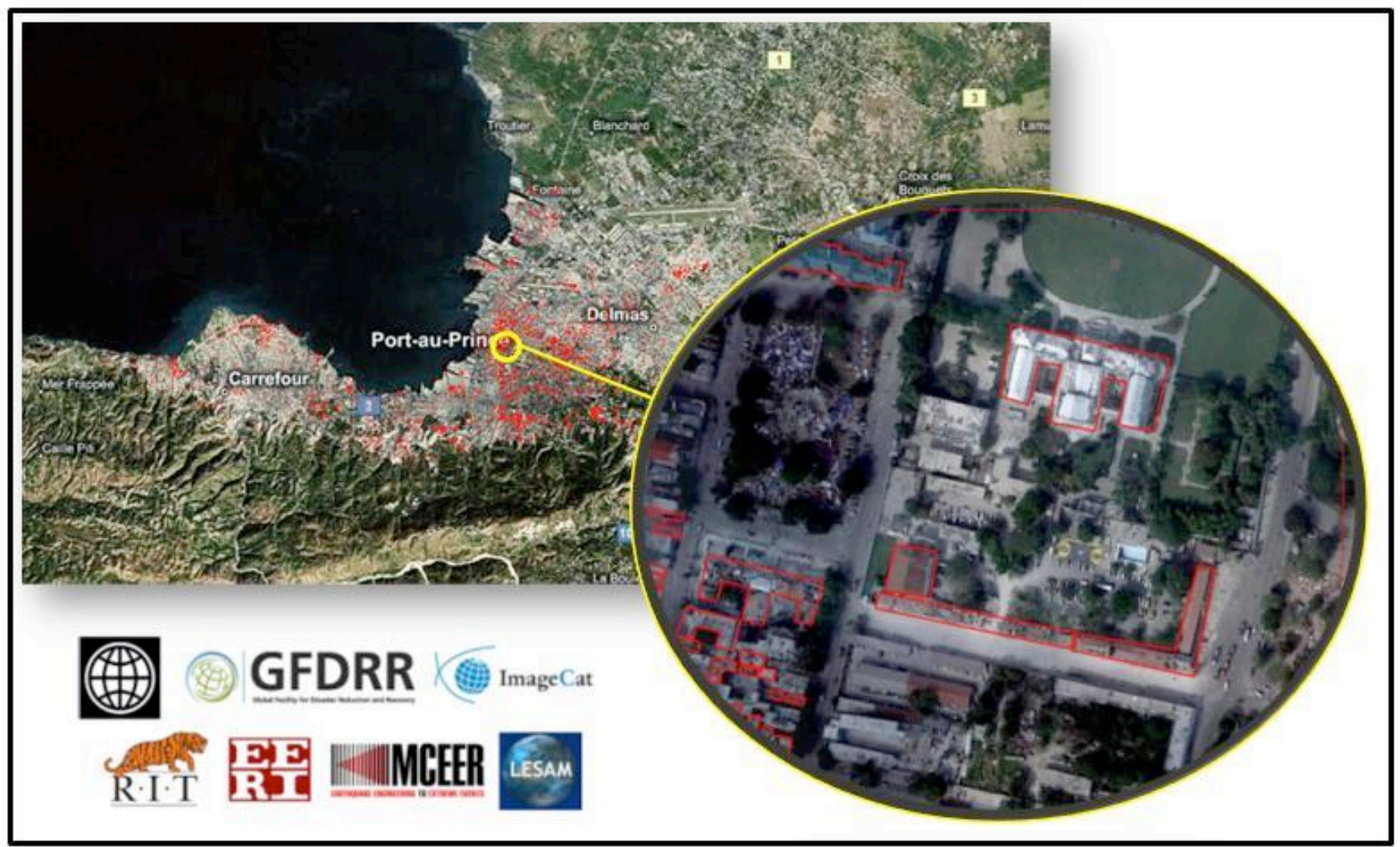

Figure 54. Sample of Damage Assessment Map.

The National Geospatial-Intelligence Agency (NGA) is also using high-resolution aerial images and LIDAR technology. They have created maps of damaged regions and have used LIDAR mapping from flyovers of the area to determine locations where rubble has blocked roads. The data are of sufficient 
accuracy that they can be used to approximate the volume of rubble that must be removed. Other agencies that are developing and using aerial imagery for recovery efforts include the German Space Agency (DLR), Information Technology for Humanitarian Assistance Cooperation and Action (ITHACA), and the United Nations Operational Satellite Applications Program (UNOSAT).

Many of these organizations have made their imagery available to those who are involved in the recovery and rebuilding efforts. For example, figure 55, which shows damage assessment and field medical locations for Port-au-Prince, is an example of collaboration among these agencies. This figure combines the information provided by the SOUTHCOM-NGA, ITHACA, UNOSAT, and German DLR. It was created by and in coordination with the U.S. Department of Homeland Security, the UN, and USAID (ReliefWeb, 2010).

The significant amount of effort put into developing imagery-evaluation techniques for this event and the collaboration among numerous agencies are testaments to both to the magnitude of the event and the possibilities for these technologies to have a larger role in future natural disaster response and recovery. 


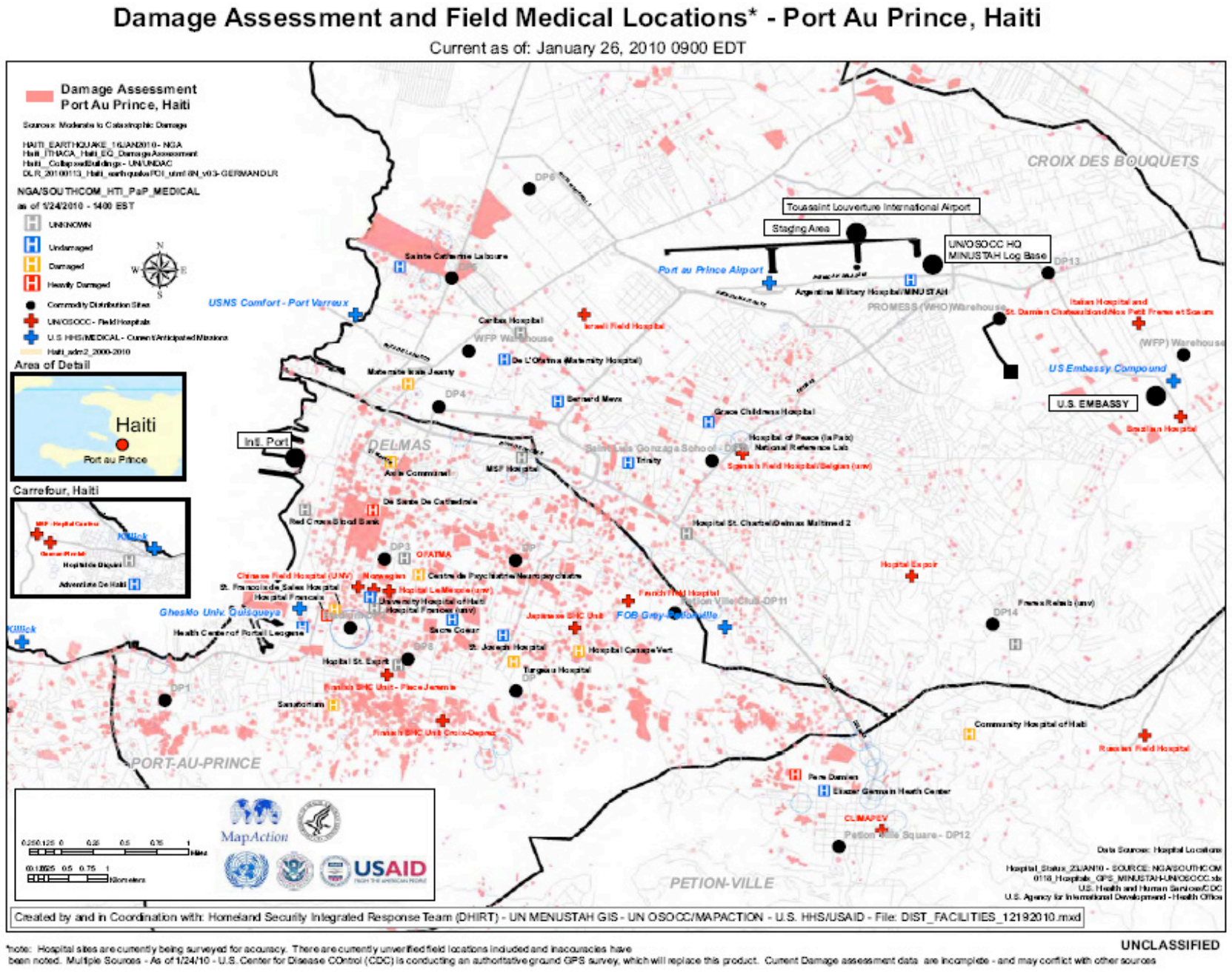

Figure 55. Damage assessment and field medical locations (Relief Web, 2010). 


\section{Final Remarks}

There were no seismographic stations in Haiti during the main earthquake or its largest aftershocks, so it is impossible to estimate accurately the intensity of ground motions. Nonetheless, indirect evidence suggests that the earthquake did not produce ground motions sufficient to severely damage well-engineered structures. For example, the Digicel Building (fig. 15B) and the U.S. Embassy survived the earthquake with little damage. The Union School buildings (fig. 29) showed no signs of being subjected to large deformation demands. Many bearing-wall structures did survive the earthquake, even though they are unlikely to have had ductile details. Similarly, bridges located near the epicenter suffered only minor damage and were able to function immediately after the earthquake.

It appears that the widespread damage to residences, government and private buildings, roadways, and port facilities was attributable to a great extent to the lack of attention in design and construction to the possibility of earthquakes. In many cases, the structural types, member dimensions, detailing practices, and fill properties were inadequate to resist strong ground motions. These vulnerabilities may have been exacerbated by poor construction practices. The effects of this damage were also compounded by widespread poverty, the high population density of Port-au-Prince, and the fragility of the public institutions in Haiti.

We hope that the reconstruction efforts in Haiti will encourage the design and construction of locally appropriate, seismically resistant structures that will be much less vulnerable to future earthquakes. The world community should work to reduce the vulnerabilities of similar regions elsewhere. 


\section{References}

Central Intelligence Agency, 2010, The Central Intelligence Agency World Factbook

[https://www.cia.gov/library/publications/the-world-factbook/index.html accessed on February 10, 2010].

Edwards, J.D., 1994, The Origins of Creole Architecture: Winterthur Portfolio, v. 29, no. 2/3 (Summer Autumn), p. 155-189 [http://www.jstor.org/action/showPublication?journalCode=wintport accessed on March 2, 2010].

Emmanuel, E., Joseph, O., Naider Fanfan, P., and Winiarski, T., 2004, Trend analysis of the groundwater salinity of the Cul-de-Sac aquifer in Haiti: AIDIS, Forjando el Ambiente que Compartimos, San Juan, 1-8.

Fierro, E., and Perry, C., 2010, Preliminary Reconnaissance Report - 12 January 2010 Haiti Earthquake: BFP Engineers, $12 \mathrm{p}$.

Garcia-Casco, A., Iturralde-Vinent, M.A., and Pindell, J., 2008, Latest Cretaceous collision/accretion between the Caribbean Plate and Caribeana; origin of metamorphic terranes in the Greater Antilles: International Geology Review, v. 50, p. 781-809.

Hayes, G., 2010, USGS finite-fault model for January 12, 2010, Haiti Earthquake:

[http://earthquake.usgs.gov/earthquakes/eqinthenews/2010/us2010rja6/finite fault.php accessed on March 2, 2010].

Institute Haïtien de Statistique et d'Informatique, 2003, Enquête sure les Conditions de Vie de Haïti. (Investigation of the Living Conditions in Haiti): Ministère de L'Economie et des Finances, 62 p.

Institute Haïtien de Statistique et d'Informatique, 2010a, Présentation Générale des Résultats; Batiments (General presentation of results; buildings): Ministère de L'Economie et des Finances (http://www.ihsi.ht/rgph_resultat_ensemble_b.htm accessed on February 11,2010].

Institute Haïtien de Statistique et d'Informatique, 2010b, Présentation Générale des Résultats; Glossaire (General presentation of results; glossary): Ministère de L'Economie et des Finances (http:/www.ihsi.ht/recensement_glossaire.htm accessed on February 11,2010].

Joseph, J.R., Laleau, M.-F., and Prophete, F.L.C., 2006, Inégalités et Pauvreté en Haïti (Inequality and Poverty in Haiti): Ministère de la Planification et de la Coopération Externe (MPCE) [http://www.mpce.gouv.ht/inegalitepauvretefinal.pdf accessed on March 2, 2010].

Manaker, D.M., Calais, E., Freed, A.M., Ali, S.T., Przybylski, P., Mattiolo, G., Jansma, P., Prepetit, C., and de Chabalier, J.B., 2008, Interseismic plate coupling and strain partitioning in the Northeastern Caribbean: Geophysical Journal International, v. 174, p. 889-903.

Maurrasse, F. J.-M. R., 1982, Survey of the geology of Haiti; guide to the field excursions in Haiti of the Miami Geological Society, March 3-8, 1982: Miami Geological Society, 103 p.

O’Loughlin, K.F., and Lander, J.F., 2003, Caribbean tsunamis, a 500-year history from 1498-1998: Kluwer Academic Publishers, The Netherlands, 263 p.

Relief Web, 2010, Damage assessment and field medical locations: [http://www.reliefweb.int/rw/fullmaps_am.nsf/luFullMap/24338419D7AD0A36852576BA00791D9A/\$File Imap.pdf? OpenElement accessed on January 11, 2010]. 
Risk Management Solutions, 2010, Risk Management Solutions FAQ; 2010 Haiti earthquake and Caribbean earthquake risk [http://www.rms.com/Publications/Haiti_Earthquake_FAQ.pdf accessed on February 12, 2010].

Scherer, J., 1912, Great earthquakes in the Island of Haiti: Bulletin of the Seismological Society of America, v. 2, p. 161-180.

ten Brink, U., and Andrews, B.D., 2010, USGS Tectonic Map of the Northeast Caribbean [http://woodshole.er.usgs.gov/project-pages/caribbean/accessed on March 2, 2010].

United Nations, 2010, Haiti Earthquake Situation Report \#21, February 16, 2010: United Nations Office for the Coordination of Humanitarian Affairs.

USAID (2010). United States Agency for International Development, 2010, Haiti Earthquake Fact Sheet \#29 [http://www.usaid.gov/our_work/humanitarian_assistance/disaster_assistance/ accessed on February 11, 2010].

U.S. Geological Survey, 2010, U.S. Geological Survey, significant earthquakes; magnitude 7.0 Haiti region, 2010 January 12, 21:53:10 UTC [http://earthquake.usgs.gov/earthquakes/eqinthenews/2010/us2010rja6/ accessed on March 2, 2010].

Woodring, W.P., Brown, J.S., and Burbank, W.S., 1924, Geology of the Republic of Haiti: Department of Public Works, Port-au-Prince, Republic of Haiti, Lord Baltimore Press, Baltimore, 631 p. 


\section{Appendix A. Statistics on Haitian Housing}

During 2001, the Haitian Ministry of Statistics and Informatics gathered extensive information on the living conditions in Haiti. The resulting report (Institute Haïtien de Statistique et d'Informatique, 2003) provided detailed statistics on many aspects of the housing characteristics in Haiti. This appendix provides tables that were excerpted and translated from that report.

Table A1. Percentage distribution of housing units according to type of residence (Institute Haïtien de Statistique et d'Informatique, 2010b)

\begin{tabular}{|l|r|r|r|r|}
\hline \multirow{2}{*}{ Type of Housing } & \multicolumn{2}{|c|}{ Location } & \multicolumn{2}{|c|}{ All } \\
\cline { 2 - 5 } & \multicolumn{1}{|c|}{$\begin{array}{c}\text { PaP } \\
\text { Metropolitan } \\
\text { Area }\end{array}$} & $\begin{array}{c}\text { Other Urban } \\
\text { Areas }\end{array}$ & \multicolumn{2}{|c|}{ Rural } \\
\hline $\begin{array}{l}\text { Kay atè (combined roof and } \\
\text { walls) }\end{array}$ & 0.3 & 6.6 & 8.7 & 6.4 \\
\hline Taudis/Ajoupas & 2.5 & 9.4 & 19.0 & 63.5 \\
\hline Ordinary One-Story House & 62.7 & 71.6 & 61.4 & 7.2 \\
\hline $\begin{array}{l}\text { Ordinary Multistory } \\
\text { House/Apartment }\end{array}$ & 30.3 & 7.7 & 1.8 & 100.0 \\
\hline Others & 4.2 & 4.7 & 9.1 & 7,186 \\
\hline Total & 100.0 & 100.0 & 100.0 & 4.0 \\
\hline Sample & 1,002 & 1,541 & 4,643 & \\
\hline
\end{tabular}

Table A2. Percentage distribution of housing units according to roof type (Institute Haïtien de Statistique et d'Informatique, 2010b)

\begin{tabular}{|l|r|r|r|r|r|}
\hline \multirow{2}{*}{ Type of Housing } & \multicolumn{4}{|c|}{ Type of Roof } & \\
\cline { 2 - 6 } & Concrete & Sheet Metal & \multicolumn{1}{|c|}{ Straw } & $\begin{array}{l}\text { Thatch/Palm } \\
\text { leaves/others }\end{array}$ & Total \\
\hline $\begin{array}{l}\text { Kay atè (combined } \\
\text { roof and walls) }\end{array}$ & - & - & 47.3 & 52.7 & 100.0 \\
\hline Taudis/Ajoupas & - & 44.7 & 40.6 & 14.7 & 100.0 \\
\hline $\begin{array}{l}\text { Ordinary One-Story } \\
\text { House }\end{array}$ & 10.5 & 81.9 & 5.8 & 1.8 & 100.0 \\
\hline $\begin{array}{l}\text { Ordinary Multistory } \\
\text { House/Apartment }\end{array}$ & 70.9 & 20.4 & - & 8.7 & 100.0 \\
\hline $\begin{array}{l}\text { Others } \\
\text { All }\end{array}$ & 7.1 & 69.5 & 13.2 & 10.2 & 100.0 \\
\hline
\end{tabular}


Table A3. Percentage distribution of housing units according to wall type (Institute Haïtien de Statistique et d'Informatique, 2010b)

\begin{tabular}{|c|c|c|c|c|c|}
\hline \multirow[b]{2}{*}{ Type of Housing } & \multicolumn{4}{|c|}{ Type of Wall } & \multirow[b]{2}{*}{ Total } \\
\hline & $\begin{array}{c}\text { Concrete/ } \\
\text { Blocks/Stone }\end{array}$ & Earth & Wood/Planks & Others & \\
\hline $\begin{array}{l}\text { Kay atè (combined } \\
\text { roof and walls) }\end{array}$ & - & 74.1 & - & 25.9 & 100.0 \\
\hline Taudis/Ajoupas & - & 42.6 & 20.0 & 37.4 & 100.0 \\
\hline $\begin{array}{l}\text { Ordinary One-Story } \\
\text { House }\end{array}$ & 75.7 & - & 8.3 & 16.0 & 100.0 \\
\hline $\begin{array}{l}\text { Ordinary Multistory } \\
\text { House/Apartment }\end{array}$ & 96.8 & - & 1.3 & 1.9 & 100.0 \\
\hline Others & 48.2 & 17.0 & 17.8 & 17.0 & 100.0 \\
\hline All & 60.6 & 11.7 & 9.4 & 18.3 & 100.0 \\
\hline
\end{tabular}

Table A.4. Percentage distribution of housing units according to floor type (Institute Haïtien de Statistique et d'Informatique, 2010b)

\begin{tabular}{|c|c|c|c|c|c|}
\hline \multirow[b]{2}{*}{ Type of Housing } & \multicolumn{4}{|c|}{ Type of Floor } & \multirow[b]{2}{*}{ Total } \\
\hline & Concrete & Beaten Earth & $\begin{array}{c}\text { Mosaic/Plank } \\
\text { S }\end{array}$ & Others & \\
\hline $\begin{array}{l}\text { Kay atè (combined } \\
\text { roof and walls) }\end{array}$ & - & 93.4 & - & 6.6 & 100.0 \\
\hline Taudis/Ajoupas & - & 86.7 & - & 13.3 & 100.0 \\
\hline $\begin{array}{l}\text { Ordinary One-Story } \\
\text { House }\end{array}$ & 64.0 & 31.0 & 1.7 & 3.3 & 100.0 \\
\hline $\begin{array}{l}\text { Ordinary Multistory } \\
\text { House/Apartment }\end{array}$ & 68.6 & - & 23.8 & 7.6 & 100.0 \\
\hline Others & 25.6 & 47.6 & 3.5 & 23.3 & 100.0 \\
\hline All & 48.9 & 40.8 & 3.6 & 6.7 & 100.0 \\
\hline
\end{tabular}

The Kay atè, Taudis, and the Ajoupas are housing for the poor and extremely poor (Joseph and others, 2006). The Kay atè resembles a tent in which the roof and walls are combined. The roof is generally made of straw, thatch, or palm leaves. The floor usually consists of compacted earth (Institute Haitien de Statistique et d'Informatique, 2010b).

The term "Taudis" refers to slum housing made mainly of waste construction materials. The roof can be made of palm leaves, corrugated sheet metal, or cardboard. The walls can be made of clissage (intertwined sticks, twigs, and branches) alone, clissage and bousillage (a mixture of clay and fiberous substances), recovered sheet metal, waste blocks, or wood. The floor nearly always consists of beaten earth (Institute Haitien de Statistique et d'Informatique, 2010b). The term "Ajoupas" refer to the building type found in rural areas. The roof can be made of thatch, straw, or palm leaves. The walls can be made of clissage and bousillage, stone, or planks. The floor generally consists of compacted earth (Institute Haïtien de Statistique et d'Informatique, 2010b). 